\title{
Busca Guiada de Patentes de Bioinformática
}

\author{
Marcio Branquinho Dutra
}

DISSERTAÇÃO APRESENTADA
AO
PROGRAMA INTERUNIDADES EM BIOINFORMÁTICA
DA
UNIVERSIDADE DE SÃO PAULO
PARA
OBTENÇÃO DO GRAU DE MESTRE
EM
CIÊNCIAS

Programa: Mestrado em Bioinformática

Orientadora: Prof ${ }^{\mathrm{a}}$. Dr ${ }^{\mathrm{a}}$ Alessandra Alaniz Macedo

Ribeirão Preto

Agosto de 2013 


\section{Busca Guiada de Patentes de Bioinformática}

Este exemplar corresponde à redação final da dissertação submetida à comissão julgadora apresentado por Marcio Branquinho Dutra ao Programa Interunidades de Mestrado em Bioinformática da Universidade de São Paulo

Banca Examinadora:

- Prof ${ }^{a}$. Dr ${ }^{a}$ Alessandra Alaniz Macedo

- Prof ${ }^{a}$. Dra Elza Helena Andrade Barbosa Durham

- Prof ${ }^{\mathrm{a}}$. Dra Nina Sumiko Tomita Hirata 
Aos meus pais, Antonio e Ilza, à minha irmã, Renatha e ao meu padrinho Olivio. 


\section{Agradecimentos}

Aos Céus pelo amparo e força em todos os momentos da minha caminhada.

À minha família: meu pai Antonio, minha mãe Ilza, minha irmã Renatha, minha sobrinha e afilhada Maria Eduarda (Dudu), ao meu, hoje cunhado, mas antes irmão, Renan, aos meus avós Geralda e Olivio (in memoriam), ao meu padrinho Olivio Filho, à minha madrinha Ana, à minha tia Flora e à minha prima Robertha. Agradeço à todos por todo o apoio e também por todos os momentos de descontração, preocupação, alegrias e tristezas compartilhadas nesse período. Se a família é a base de um homem, vocês são a minha estrutura. Se cheguei onde estou, muito se deve à vocês que sempre me deram ótimos exemplos, ensinaram, apoiaram e incentivaram. Obrigado por optarem compartilhar dessa existência comigo.

À minha orientadora Prof ${ }^{\mathrm{a}}$. Dra ${ }^{\mathrm{a}}$. Alessandra Alaniz Macedo pelo aprendizado nesse período de mestrado e por acreditar na realização deste trabalho.

Ao marido de minha orientadora, Antonio Camacho-Guerrero pelas colaborações e elucidações sobre sistemas de Recuperação de Informação.

Ao Prof. Dr. Ricardo Vêncio pela orientação e colaboração, especialmente antes do início do mestrado. Sua disciplina de estatística me auxiliou muito, inclusive na prova de seleção para ingresso no mestrado.

Ao Prof. Dr. José Augusto Baranauskas pelas elucidações referentes à classificação automática.

À Prof ${ }^{\mathrm{a}}$. Dra . Nina Hirata pelas orientações que me forneceu, mesmo após a qualificação.

À secretária do Programa Interunidades de Bioinformática, Patrícia Martorelli pela atenção e solicitude com que sempre me tratou e pelas inúmeras orientações e resoluções de questões burocráticas durante o mestrado.

Ao meu amigo Lucas Pellozo, por todo apoio e incentivo ao longo de todo esse período.

À minha colega e veterana de mestrado Juliana Polletini pelos infinitos auxílios. 
Também aos colegas de mestrado Érica Tanaka, Pedro Santoro Perez e Daniane de Paula por toda a atenção com que sempre me trataram, pelas trocas de ideias e inúmeras ajudas.

Ao meu gerente na Coderp, Ernani, por compreender a importância desse projeto para a minha vida profissional e me liberar do trabalho sempre que eu precisei.

Aos meus professores de inglês Paulo Gregório, Gilcinei Tiago e Vanessa. Sem vocês dificilmente eu teria sido aprovado no exame de proficiência em inglês para o mestrado.

A todos que de alguma maneira contribuíram para a realização deste trabalho, familiares, professores e colegas. O resultado colhido hoje foi construído por todos esses momentos em conjunto com vocês. 
"It's a long way to the top, if you wanna rock'n'roll." $A C / D C$ 


\section{Resumo}

As patentes são licenças públicas temporárias outorgadas pelo Estado e que garantem aos inventores e concessionários a exploração econômica de suas invenções. Escritórios de marcas e patentes recomendam aos interessados na concessão que, antes do pedido formal de uma patente, efetuem buscas em diversas bases de dados utilizando sistemas clássicos de busca de patentes e outras ferramentas de busca específicas, com o objetivo de certificar que a criação a ser depositada ainda não foi publicada, seja na sua área de origem ou em outras áreas. Pesquisas demonstram que a utilização de informações de classificação nas buscas por patentes melhoram a eficiência dos resultados das consultas. A pesquisa associada ao trabalho aqui reportado tem como objetivo explorar artefatos linguísticos, técnicas de Recuperação de Informação e técnicas de Classificação Textual para guiar a busca por patentes de Bioinformática. O resultado dessa investigação é o Sistema de Busca Guiada de Patentes de Bioinformática (BPS), o qual utiliza um classificador automático para guiar as buscas por patentes de Bioinformática. A utilização do BPS é demonstrada em comparações com ferramentas de busca de patentes atuais para uma coleção específica de patentes de Bioinformática. No futuro, deve-se experimentar o BPS em coleções diferentes e mais robustas. 


\section{Abstract}

Patents are temporary public licenses granted by the State to ensure to inventors and assignees economical exploration rights. Trademark and patent offices recommend to perform wide searches in different databases using classic patent search systems and specific tools before a patent's application. The goal of these searches is to ensure the invention has not been published yet, either in its original field or in other fields. Researches have shown the use of classification information improves the efficiency on searches for patents. The objetive of the research related to this work is to explore linguistic artifacts, Information Retrieval techniques and Automatic Classification techniques, to guide searches for Bioinformatics patents. The result of this work is the Bioinformatics Patent Search System (BPS), that uses automatic classification to guide searches for Bioinformatics patents. The utility of BPS is illustrated by a comparison with other patent search tools. In the future, BPS system must be experimented with more robust collections. 


\section{Lista de Figuras}

1 Pedidos e concessões no INPI entre 2005 e 2009 (Elaborado de acordo com (INPI, 2010b) (INPI, 2009)). Acessado em Julho/2013. . . . . . . . . . . . 26

2 Matrizes de interação entre ciência e tecnologia dos Estados Unidos e Brasil em 2006 (RIBEIRO et al., 2010). Acessado em Julho/2013. . . . . . . . . . . . . 28

3 Depósito de patentes no INPI de residentes no Brasil, por tipo de patente, segundo subdomínios tecnológicos do OST - 1980-2005 (FAPESP, 2010). Acessado em Julho $/ 2013 . \ldots \ldots$. . . . . . . . . . . . . . . 29

4 Visão lógica do documento (BAEZA-YATES; RIBEIRO-NETO, 1999). . . . . . . . 49

5 Representação dos conjuntos de documentos que são base para os cálculos de Precisão e revocação (BAEZA-YATES; RIBEIRO-NETO, 1999). . . . . . . . . . . 51

6 Exemplo de estrutura da Gene Ontology com um pequeno conjunto de termos pertencentes à ontologia de Processos Biológicos. (THE GENE ONTOLOGY CONSORTIUM, 2013c) . . . . . . . . . . . . . . 54

7 Casos de uso e atores do sistema de busca guiada de patentes de Bioinformática

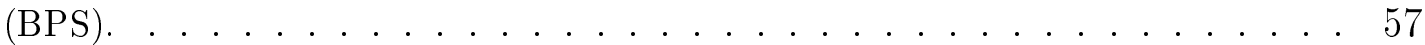

8 Arquitetura do sistema de busca guiada de patentes de Bioinformática. . . . . . 58

9 Visão geral do filtro utilizado no sistema de busca guiada de patentes de Bioin-

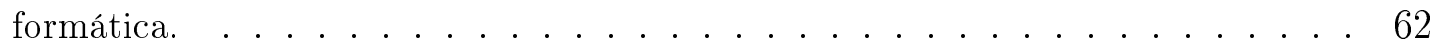

10 Visão geral do processamento de similaridade do sistema de busca guiada de patentes de Bioinformática. . . . . . . . . . . . . . . . . . . 64

11 Interface de pesquisa de patentes do sistema BPS. . . . . . . . . . . . . . 66

12 Interface de visualização dos detalhes da patente. . . . . . . . . . . . . 66

13 Distribuição de documentos por classes de Bioinformática. . . . . . . . . . . . . 68 


\section{Lista de Tabelas}

1 Exemplo de classificação USPC . . . . . . . . . . . . . . . . . . . 24

2 Classes USPC de Bioinformática e hierarquias (USPTO, 2012). . . . . . . . . 24

3 Conjunto de treinamento apresentado como entrada a um algoritmo de treinamento único rótulo. (MONARD; BARANAUSKAS, 2003) . . . . . . . . . . 35

4 Exemplo de um conjunto de treinamento multirrótulo (TSOUMAKAS et al., 2010). 38

5 Conjuntos de treinamento transformados em único rótulo. (a) cópia, (b) cópiacom-peso, $(c)$ seleção-max, $(d)$ seleção-min, $(e)$ seleção-aleatória e $(f)$ descarte (TSOUMAKAS et al., 2010). . . . . . . . . . . . . . . . . 39

6 Conjuntos de treinamento transformados em único rótulo utilizando o método LP (TSOUMAKAS et al., 2010) . . . . . . . . . . . . . . . . . 40

$7 \quad$ Coleções utilizadas na análise dos classificadores. . . . . . . . . . . . . . . 69

8 Resumo dos algoritmos com melhores valores para cada métrica observada. . . . 71

9 Resumo dos melhores valores obtidos pelo algoritmo RAkEL com NBM. . . . . . 73

10 Ranking de classes gerado pelo filtro para cada documento pesquisado. . . 79

11 Números das patentes resultantes das buscas com o Documento \#1 US6882939 (702/19) - Rapid determination of protein global folds. . . . . . 80

12 Números das patentes resultantes das buscas com o Documento \#2 US8296075 (702/20) - Computer system and computer-facilitated method for nucleic acid sequence alignment and analysis. . . . . . . . . . . . . . 80

13 Números das patentes resultantes das buscas com o Documento \#3 US4063309 (702/21) - Mean corpuscular volume measuring apparatus and method.

14 Números das patentes resultantes das buscas com o Documento \#4 US8271250 (703/11) - Molecule design support apparatus and computerreadable 
15 Números das patentes resultantes das buscas com o Documento \#5 US8271251 (703/12) - Automated imaging system for single molecules). . . 82

16 Precisão de busca de documentos das ferramentas utilizadas nos experimentos de Recuperação de Informação. . . . . . . . . . . . . . . . . . 83

17 Quantidade total e precisão de documentos retornados pelas buscas que possuem a mesma classificação do documento consultado. . . . . . . . . . . 84

18 Comparativo de relevância dos documentos retornados pelas consultas que apresentam classificação diferente do documento consultado para BPS e BPS-GO . . . . . . . . . . . . . . . . . 85

19 Classes USPC de Bioinformática e hierarquias (USPTO, 2012). . . . . . . . . 95 


\section{Sumário}

1 Introdução 14

1.1 Motivação . . . . . . . . . . . . . . . . . . 15

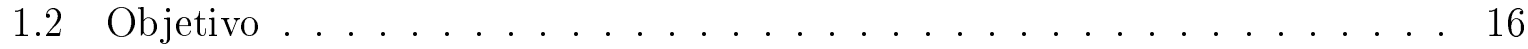

1.3 Principais Contribuições . . . . . . . . . . . . . . . . . 17

1.4 Trabalhos Relacionados . . . . . . . . . . . . . . . 17

1.5 Organização do Documento . . . . . . . . . . . . . . 19

2 Sistema de Propriedade Intelectual 20

2.1 Caracterização de Patentes . . . . . . . . . . . . . . . . . 21

2.2 Classificação de Patentes . . . . . . . . . . . . . . . . . 23

2.3 Patentes Brasileiras . . . . . . . . . . . . . . . 25

2.4 Requisitos e Roteiro para o Pedido de Patente no Brasil . . . . . . . . . . 30

2.5 Patentes de Bioinformática . . . . . . . . . . . . . . 32

3 Classificação Automática de Textos 34

3.1 Conceitos Gerais . . . . . . . . . . . . . . . . 34

3.1 .1 Classificação Único Rótulo e Multirrótulo . . . . . . . . . . . . . 36

3.1.1.1 Transformação do Problema . . . . . . . . . . . . 38

3.1.1.2 Adaptação de Algoritmos . . . . . . . . . . . . . . 40

3.1.2 Avaliação de Classificadores Multirrótulo . . . . . . . . . . . . . 41

3.2 Classificação Automática de Patentes . . . . . . . . . . . . . . . . 43

3.3 Mineração de Texto Aplicada à Bioinformática . . . . . . . . . . . . . . . 46 
4 Recuperação de Informação 48

4.1 Recuperação de Informação Textual . . . . . . . . . . . . . . . . . . . 48

4.2 Avaliação de Recuperação de Informação Textual . . . . . . . . . . . . . 51

4.3 Artefatos Linguísticos para IR em Bioinformática . . . . . . . . . . . 52

5 Sistema de Busca Guiada de Patentes de Bioinformática (BPS) 56

5.1 Análise, Projeto e Arquitetura do Sistema . . . . . . . . . . . 56

5.2 Módulos de Processamento Textual, Classificação e Recuperação de Informação do Sistema BPS . . . . . . . . . . . . . . . . . . 60

5.2.1 Identificação de Conceitos de Bioinformática: GO como Artefato Linguístico . . . . . . . . . . . . . . . . . 60

5.2.2 Avaliação e Escolha do Modelo de Classificação . . . . . . . . . . . 61

5.2 .3 Processamento de Similaridades . . . . . . . . . . . . . . 63

5.3 O Sistema BPS . . . . . . . . . . . . . . . . . 64

6 Experimentações e Resultados $\quad 67$

6.1 O Repositório de Patentes . . . . . . . . . . . . . . 67

6.2 Experimento I: Componente de Classificação . . . . . . . . . . . . . . . 69

$6.2 .1 \quad$ Preparação . . . . . . . . . . . . . . . . . 69

6.2.2 Resultados ........................ 70

6.3 Experimento II: Componentes de Classificação e Recuperação de Informação 74

$6.3 .1 \quad$ Preparação . . . . . . . . . . . . . . . . 75

6.3.2 Resultados das Classificações . . . . . . . . . . . . . 78

6.3.3 Resultados das Buscas .................. 79

7 Conclusão

Referências 


\section{Introdução}

A inovação tem sido considerada um importante elemento no desenvolvimento social e econômico da sociedade (FAGERBERG et al., 2006). Historicamente, o ser humano utiliza sua capacidade de raciocínio para criar ou melhorar objetos existentes a fim de aplicálas em suas atividades. Inovação e invenção têm seus sentidos comumente confundidos, devido ao fato de serem termos conceitualmente próximos. Segundo (FAGERBERG et al., 2006), a invenção é a primeira ocorrência de uma criação ou aprimoramento de um objeto, tecnologia ou processo. Por outro lado, a inovação é a primeira ocorrência da aplicação de uma invenção. Visando reconhecer os direitos autorais do inventor e proporcionar vantagem competitiva àqueles que inovam, a partir do século XV, governos na Europa criaram as patentes.

Ao outorgar documentos de patentes, o Estado concede aos titulares da patente licenças públicas temporárias de exploração econômica sobre as invenções (BARBOSA, 2003). As patentes garantem a proteção ao direito de exclusividade na fabricação, utilização, licenciamento e venda do invento apenas nos países onde foram concedidas. Patentes não são válidas em países que não possuem legislação sobre patentes e em países cujo o pedido não tenha sido depositado ou o pedido depositado tenha sido negado. Como contrapartida às vantagens de obter a outorga de uma patente, o titular fica obrigado a divulgar o trabalho em revistas específicas publicadas pelos órgãos de análise e concessão de cada país, descrevendo todos os detalhes técnicos, a fim de divulgar os avanços tecnológicos atingidos com a invenção (BARBOSA, 2003).

A preservação dessas garantias é considerada um instrumento de motivação para que inventores e titulares deem continuidade ao processo de desenvolvimento tecnológico mundial. Pesquisas recentes demonstram que as patentes armazenam em torno de $70 \%$ do conhecimento mundial. As patentes disponibilizam informações técnicas mais detalhadas que artigos científicos, auxiliam na divulgação do conhecimento e estimulam o desenvolvimento tecnológico de diversas áreas (LUPU et al., 2011) (USP, 2011). 
Entre as áreas que se utilizam das patentes está a Bioinformática, que é um campo multidisciplinar formado pela convergência de tecnologias biológicas, biomédicas e da informação (BAXEVANIS; OUELLETTE, 2004). De acordo com (RASMUSSEN, 2005), a análise e a classificação de patentes são processos complexos, especialmente quando tratam de novas tecnologias formadas pela combinação de outras tecnologias existentes, como é o caso da Bioinformática. Os profissionais da área devem conhecer todos os aspectos da multidisciplinaridade para elaborar, analisar e classificar patentes de tecnologias convergentes.

\subsection{Motivação}

Atualmente, todos os escritórios de marcas e patentes têm sido criticados mundialmente devido ao tempo para a análise de cada pedido (INPI, 2011a) (RODRIGUEZ, 2010) (REID, 2011). No Brasil o INPI despende oito anos, em média, para analisar e emitir o parecer final (INPI, 2011b). Em outros importantes órgãos como o americano USPTO (United States Patent and Trademark Office) e o europeu EPO (European Patent Office), cada pedido de patente é analisado e finalizado, em média, em quatro anos (USPTO, 2012) (EPO, 2011). Essa demora no Brasil e no exterior ocorre devido à quantidade de pedidos depositados, à quantidade de examinadores, à quantidade e qualidade de ferramentas computacionais que auxiliam nas análises e pesquisas de patentes similares (USPTO, 2012) (EPO, 2011)(INPI, 2011b).

O processo de análise de pedidos de patentes é complexo e caro. Por isso, escritórios de marcas e patentes sugerem aos interessados na concessão que, antes do pedido formal, efetuem buscas amplas em diversas fontes como bases de informações de patentes nacionais e internacionais, revistas especializadas e publicações técnicas e científicas, utilizando os sistemas clássicos de busca ou outras ferramentas de busca específicas, com o objetivo de certificar que a criação a ser depositada ainda não foi publicada, seja na sua área de origem ou em outras áreas (INPI, 2008) (INPI, 2012). Nesse contexto, segundo (PARK, 2012), (EISINGER et al., 2012) e (USPTO, 2013b), a busca textual é o método mais utilizado nas pesquisas por anterioridade e a utilização de informações adicionais, especialmente de classificação, nestes sistemas é importante para guiar as buscas e torná-las mais eficientes.

Além da pesquisa por anterioridade, sistemas de busca de patentes são utilizados para encontrar tecnologias similares que possam embasar a pesquisa e o desenvolvimento de novos produtos (INPI, 2012). A busca por patentes vigentes similares e patentes em 
aniversário $^{1}$ são utilizadas por empresas interessadas em fabricar tais produtos.

Atualmente, a Internet facilitou o acesso a bases de dados de patentes ao proporcionar pesquisas on-line gratuitas nos sites de diversos escritórios de marcas e patentes e no Google ${ }^{2}$. Apesar dos esforços dos escritórios e do Google em disponibilizar gratuitamente ferramentas eficientes de busca, nota-se que as ferramentas e bases de dados comerciais privadas ainda apresentam mais recursos do que as aplicações gratuitas (vide Apêndice B). Devido aos altos custos de uma licença de utilização, a contratação de ferramentas comerciais, como o Derwent e o Dialog, se torna inviável para pequenas e médias empresas brasileiras de pesquisa. Nesse contexto, é interessante a disponibilização de ferramentas gratuitas de busca que apresentem recursos complementares aos recursos das ferramentas gratuitas atuais, oferecendo, assim, alternativas de qualidade para pequenas e médias empresas brasileiras de pesquisa que precisam fazer buscas por patentes e não podem arcar com os altos custos de uma ferramenta comercial.

De acordo com o manual de exame de patentes do USPTO, existem também ferramentas de busca especializadas em determinadas tecnologias, como estruturas químicas, sequenciamento de DNA e outras. O manual aponta que a utilização desses sistemas aumenta a eficiência de busca nessas áreas, pois essas ferramentas são preparadas para lidar com termos, códigos e jargões específicos (USPTO, 2013b). Diante desse cenário, uma abordagem interessante para o desenvolvimento de uma nova ferramenta seria aplicá-la à uma área específica. Esse direcionamento pode ser implementado utilizando artefatos linguísticos da área a qual se deseja focar. Por exemplo, para sistemas especializados em Bioinformática, pode-se utilizar as ontologias da OBO como a Gene Ontology (vide Seção 4.3) ou o GENIA Ontology (vide Seção 3.3). Artefatos linguísticos podem identificar termos, códigos e jargões específicos e agregar maior representatividade à esses termos.

\subsection{Objetivo}

O objetivo deste trabalho é explorar artefatos linguísticos, técnicas de Recuperação de Informação e técnicas de Classificação Textual para guiar a busca por patentes de Bioinformática. O resultado dessa investigação é o Sistema de Busca Guiada de Patentes

\footnotetext{
1 "Documentos de patente de invenção (PI) completando 20 anos a partir da data de depósito e documentos de modelo de utilidade (MU) completando 15 anos a partir da data de depósito, prazos estes que correspondem aos prazos de vigência dos mesmos, constituindo portanto uma indicação de patentes provavelmente já em domínio público."(INPI, 2012)

${ }^{2}$ http://www.google.com/patents
} 
de Bioinformática (BPS), o qual apoia basicamente dois tipos de busca ${ }^{3}$ : (i) pesquisas por anterioridade de tecnologias presentes na área de Bioinformática, mas que também possuem aplicação em outras áreas além da Bioinformática e (ii) pesquisas de patentes similares que podem servir como base para a criação de novas tecnologias e produtos. Essas buscas podem ser efetuadas antes da efetivação de um depósito ou durante o processo de análise de concessão.

\subsection{Principais Contribuições}

O presente trabalho investigou a classificação automática de patentes de Bioinformática utilizando documentos de patentes e taxonomia americanas e, como resultado, implementou um classificador. O Sistema de Busca Guiada de Patentes de Bioinformática (BPS) foi desenvolvido. Este sistema, diferentemente de outras ferramentas, utiliza um classificador automático para guiar as buscas. Primeiramente ele classifica os termos de entrada para restringir as subclasses de Bioinformática à qual o texto buscado possa pertencer e, em seguida, calcula as similaridades com as patentes da mesma classe exibindo um ranking.

\subsection{Trabalhos Relacionados}

Em (EISINGER et al., 2012), os autores fazem uma análise comparativa da utilização de termos MeSH e informações de classificação da taxonomia internacional (IPC) para aumentar a recuperação de documentos relevantes em buscas por patentes biomédicas. O trabalho encontra similaridades nas estruturas dos dois artefatos, mas aponta o IPC como mais complexo e menos acessível por utilizar muitos códigos. Enquanto isso, o MeSH utiliza termos inteligíveis, o que facilita sua utilização por usuários menos especializados. Neste artigo, os autores propõem alternativas para expandir consultas baseadas em palavras-chave.

(PARK, 2012) efetua análise comparativa de buscas por patentes de Bioinformática utilizando apenas palavras-chave e palavras-chave associadas à informações de classificação. Os autores utilizaram patentes disponibilizadas pelo escritório coreano $\left(\mathrm{KIPO}^{4}\right)$ por meio

\footnotetext{
${ }^{3}$ Segundo o escritório internacional (WIPO), existem diferentes tipos de busca de patentes. As abordagens variam de acordo com os objetivos da busca, escopo, data de publicação e outras variáveis. Maiores informações são encontradas em: http://www.wipo.int/patentscope/en/data/patent_information.html

${ }^{4}$ http://www.kipo.go.kr/en
} 
do sistema KIPRIS ${ }^{5}$. Para identificar as classes IPC de Bioinformática foi utilizado o sistema USPC-to-IPC reverse concordance system ${ }^{6}$ de correspondência entre USPC e IPC. Os autores apontam que a utilização de informações de classificação aumentou a quantidade de documentos relevantes recuperados e propõem análises mais detalhadas em trabalhos futuros.

(TEIXEIRA et al., 2012) propõem um método de indexação automática de artigos científicos da área de Informática em Saúde utilizando o algoritmo de classificação Multinomial Naive Bayes. O autores apontam que a grande quantidade de publicações da área e sua característica interdisciplinar exigem ferramentas computacionais eficientes que auxiliem na indexação e na recuperação de documentos. Os resultados encontrados foram considerados satisfatórios na indexação de artigos. Os autores sugerem como uma das atividades futuras, a aplicação de técnicas de redução de dimensionalidade visando melhorar o desempenho do classificador utilizado.

Assim como e (EISINGER et al., 2012) e (PARK, 2012), o presente trabalho utiliza informações de classificação e artefatos linguísticos, no caso a Gene Ontology, para melhorar a eficiência do sistema e obter relacionamentos mais relevantes. A aplicação de algoritmos de classificação em artigos de Informática em Saúde por (TEIXEIRA et al., 2012) se mostra interessante pois esta dissertação também aborda a aplicação da Classificação Textual em uma área relacionada à Saúde, que é a Bioinformática.

Como o BPS é um sistema de busca de patentes, buscou-se compará-lo com outras ferramentas existentes e de fácil acesso para o público interessado em buscas por patentes. Três ferramentas gratuitas foram selecionadas: Patent Full-Text and Image Database $\left(\right.$ PatFT) ${ }^{7}$ do USPTO, Patentscope da WIPO ${ }^{8}$ e o Google Patent Search ${ }^{9}$, que é um motor de busca do Google específico para patentes. Apenas uma ferramenta comercial foi selecionada: Derwent Innovations Index (DII ${ }^{10}$ da Thomsom Reuters. Apesar de ser comercial, o DII foi escolhido pois é disponibilizado para acesso na rede interna da Universidade de São Paulo (USP) pela Coordenação de Aperfeiçoamento de Pessoal de Nível Superior $(\mathrm{CAPES})^{11}$. No Apêndice B são exibidas as características de cada ferramenta utilizada e na Seção 6.3 é exibida a comparação entre o BPS e as outras ferramentas.

\footnotetext{
${ }^{5}$ http://www.kipris.or.kr/enghome

${ }^{6} \mathrm{http}: / /$ www.uspto.gov/web/patents/classification/international/ipc/ipc8/ipc_concordance/ipcsel.htm

${ }^{7}$ http://patft.uspto.gov

${ }^{8} \mathrm{http}: / /$ patentscope.wipo.int

${ }^{9}$ http://www.google.com/patents

${ }^{10} \mathrm{http}: / /$ wokinfo.com/products_tools/multidisciplinary/dii

${ }^{11} \mathrm{http}: / /$ www.capes.gov.br
} 


\subsection{Organização do Documento}

Os demais capítulos dessa dissertação estão organizados como segue. No Capítulo 2 são abordados conceitos sobre o Sistema de Propriedade Intelectual, patentes e classificação de patentes. A situação atual das patentes brasileiras é analisada e comparada à produção internacional. Este capítulo também descreve o roteiro para o pedido de patentes no Brasil e aborda as patentes de Bioinformática.

No Capítulo 3 são apresentados os fundamentos teóricos da área de Classificação Automática de Textos utilizados no classificador do sistema BPS. Este capítulo cita trabalhos de mineração de dados aplicados à Bioinformática, formaliza os conceitos de classificação automática de textos e o processo de avaliação de classificadores textuais.

No Capítulo 4 são abordados conceitos sobre Recuperação de Informação Textual implementados no módulo de IR do sistema BPS. O capítulo descreve formalmente o processo de IR, avaliação de Recuperação de Informação e artefatos linguísticos desenvolvidos para a área de Bioinformática.

No Capítulo 5 são apresentados o trabalho desenvolvido e a metodologia aplicada no presente trabalho. O projeto do sistema BPS é detalhado em relação aos casos de uso, atores, requisitos e arquitetura e a metodologia de utilização do classificador e aplicação da Gene Ontology apresentada.

O Capítulo 6 descreve o repositório de patentes utilizado nos experimentos, o processo de avaliação e seleção do classificador a ser utilizado como filtro pelo sistema e os experimentos e resultados obtidos na busca guiada. Na seção sobre classificação são apresentadas análises comparativas de desempenho dos algoritmos de classificação escolhidos para teste. Na seção sobre experimentos de busca são apresentadas comparações dos resultados do sistema BPS com outras ferramentas de busca de patentes disponíveis atualmente.

Por fim, no Capítulo 7 são apresentadas as conclusões. Neste capítulo são abordadas as contribuições, dificuldades e trabalhos futuros identificados ao longo dessa dissertação. 


\section{Sistema de Propriedade Intelectual}

A inovação é tratada como um fenômeno inerente à história e à evolução do ser humano, uma vez que o homem sempre utilizou sua inteligência para criar e melhorar invenções que aprimorassem a execução de suas atividades. Economicamente, a inovação representa a transformação do invento em um produto comercializável, o qual impacta positivamente no desenvolvimento social e econômico da sociedade (FAGERBERG et al., 2006). A inovação também se caracteriza por ser um processo contínuo e incremental, i.e., nem sempre uma invenção automaticamente se torna uma inovação, pois em grande parte dos casos, invenções inter-relacionadas são desenvolvidas ao longo de um período até se tornarem inovação (FAGERBERG et al., 2006).

A sociedade percebeu o aspecto inventivo e inovativo da inteligência humana e passou a criar instrumentos legais com o objetivo de proteger as obras intelectuais. Pesquisas apontam que, desde tempos remotos como no Egito antigo, Grécia antiga e no Império Romano, já existiam mecanismos de propriedade intelectual, embora não dispusessem de instituições específicas para essa finalidade (FAGERBERG et al., 2006). As instituições políticas de propriedade intelectual começaram a surgir a partir da Idade Média por meio de privilégios cedidos a determinados profissionais inventores. Pesquisadores consideram como o primeiro registro formal de propriedade intelectual uma patente datada de 1474, a qual foi outorgada pelo governo de Veneza e garantia a exclusividade na exploração econômica de um invento por um período de 10 anos (FAGERBERG et al., 2006).

No final do século XIX, após a unificação das secretarias internacionais administradoras dos tratados da Convenção de Paris (1883) sobre a proteção da propriedade industrial e da Convenção de Berna (1886) sobre a proteção de trabalhos artísticos e literários, foi criado o United International Bureaux for the Protection of Intellectual Property, o qual em 1967, já situado em Genebra, passou ser gerido pela Organização das Nações Unidas (ONU) e foi renomeado para World Intellectual Property Organization - WIPO (Orga- 
nização Mundial de Propriedade Intelectual). Desde então, a WIPO, em conjunto com os escritórios de propriedade intelectual dos países afiliados, vem atuando mundialmente na promoção da inovação como elemento de desenvolvimento econômico e social (WIPO, 2010d).

Segundo definição da WIPO, a propriedade intelectual está ligada às criações da mente humana e está dividida em Propriedade Industrial e Direito Autoral. A Propriedade Industrial trata de criações aplicáveis comercialmente e reproduzíveis industrialmente e, para se obter o direito de comercialização exclusiva, a criação deve ser registrada em órgão competente. Esse grupo abrange a proteção de patentes, marcas, desenho industrial, indicações geográficas e cultivares. Diferentemente da Propriedade Industrial, o Direito Autoral trata das criações de princípio abstrato e não obriga o registro prévio da obra para constituir a autoria. Esse grupo abrange a proteção de obras literárias e artísticas, programas de computador, domínios na Internet e cultura imaterial (WIPO, 2010e) (USP, 2011).

De acordo com o escopo do presente trabalho, neste capítulo são apresentados algumas informações sobre patentes, suas características, processos e classificações, inclusive na área de Bioinformática.

\subsection{Caracterização de Patentes}

O processo de inovação e obtenção de patentes, em geral, demanda tempo e altos investimentos humanos e financeiros. Por meio da preservação das garantias de exclusividade, o Estado reconhece o esforço dos titulares e inventores e permite que eles desfrutem de uma vantagem competitiva perante os seus concorrentes. Essa característica previne a concorrência desleal e é considerada um instrumento de motivação para que inventores, empresas ou pessoas físicas, deem continuidade ao processo de desenvolvimento tecnológico mundial (BARBOSA, 2003) (USP, 2011).

Uma mesma patente pode ser depositada e concedida, para o mesmo titular, em diversos países e, apesar de tratados internacionais também estabelecerem regras sobre as patentes, cada uma delas tem validade nacional. As patentes estão sujeitas às legislações patentárias específicas de cada país e são válidas apenas nos países onde são concedidas. Assim, a concessão de uma patente em um determinado país não garante, necessariamente, concessão em outros países (e.g., mesmo tendo patenteado um software nos Estados Unidos, o titular não consegue patenteá-lo também no Brasil, pois a legislação 
brasileira sobre patentes não contempla programas de computador) (INPI, 2008).

Tipicamente, as patentes são organizadas em Patentes de Invenção (PI), Modelo de Utilidade (MU) e Certificado de Adição de Invenção (C). As Patentes de Invenção estão relacionadas às soluções de problemas técnicos em determinadas áreas do conhecimento, de maneira que estas possam ser utilizadas industrialmente. Os Modelos de Utilidade se caracterizam pelo aperfeiçoamento ou criação de novas formas de objetos conhecidos, introduzindo melhorias de funcionalidade ou fabricação. Por fim, os Certificados de Adição abrangem melhorias desenvolvidas em inventos já patenteados. De maneira geral, patentes concedidas como PI ou C possuem período de vigência de 20 anos, enquanto patentes concedidas como MU possuem período de vigência de 15 anos (INPI, 2008).

Segundo órgãos internacionais de propriedade intelectual, o número de patentes geradas por um país está ligado diretamente ao seu desenvolvimento econômico e sua capacidade de transformar invenções em produtos inovadores (WIPO, 2010e). De acordo com o relatório (WIPO, 2010e) divulgado em setembro de 2010 pela Organização Mundial de Propriedade Intelectual (OMPI ou, na sigla em inglês, WIPO - World Intellectual Property Organization), somente em 2008, mesmo com a crise econômica mundial, nos 110 escritórios ligados à organização foram depositados 1.907 .915 pedidos e concedidas 777.556 patentes. A mesma publicação aponta que o indicador global se manteve positivo principalmente devido ao número de patentes (pedidos e concessões) de países emergentes como China, Índia e Rússia.

Entre os países com maior número de pedidos estão Estados Unidos, Japão, Alemanha e Coréia do Sul. Em 2009, esses países conjuntamente depositaram 1.043.794 ${ }^{1}$ pedidos (WIPO, 2010b) e tiveram concedidas $461.498^{1}$ patentes (WIPO, 2010c). Nesse contexto, o Brasil, apesar do crescimento econômico dos últimos anos, ainda apresenta números consideravelmente inferiores aos outros países emergentes. De acordo com estatísticas de depósitos e concessões internacionais publicadas pela WIPO ${ }^{1}$, em 2009, o Brasil efetuou 951 pedidos de patentes e obteve 284 concessões, enquanto a China depositou 240.340 pedidos e obteve 68.307 concessões. A Rússia fez 26.850 pedidos e obteve 26.861 concessões $^{2}$ e a Índia realizou 4.150 depósitos e conseguiu 1.151 concessões. Esses números se referem a pedidos internacionais a partir de tratados como o Patent Cooperation Treaty (PCT) e

\footnotetext{
${ }^{1}$ http://www.wipo.int/ipstats/en/statistics/patents/

${ }^{2}$ Apesar da quantidade de depósitos e concessões serem próximos, o número de concessões em um determinado ano não está diretamente ligado ao número de pedidos do mesmo ano, pelos escritórios de patentes demandarem tempos de análise diferentes para áreas diferentes e, por conta do grande volume de submissões atrasarem a maior parte das análises. Esse atraso é chamado de backlog e, no caso de escritórios como o americano e o europeu, esse atraso dura 4 anos em média. Ou seja, a maioria das concessões de 2009 são patentes que foram depositadas por volta de 2005.
} 
a Convenção de Paris.

Em divulgação nacional, conforme dados publicados pelo Instituto Nacional de Propriedade Industrial (INPI), órgão responsável pela análise e concessão de patentes no Brasil, em 2007, 23.221 pedidos de patente foram depositados por residentes e nãoresidentes, e 1.855 foram outorgados (INPI, 2010b). Já em 2009, foram depositados 26.524 pedidos e efetuadas 3.153 concessões (INPI, 2010b).

\subsection{Classificação de Patentes}

De acordo com (LUPU et al., 2011), uma maneira eficiente de facilitar a busca de objetos é organizá-los em grupos com características similares. Por exemplo, uma biblioteca organiza todos os livros por assuntos para facilitar a busca por livros específicos e permitir encontrar mais informação sobre o mesmo tópico ou similares. Assim, a classificação visa organizar os documentos e facilitar as pesquisas por documentos e tecnologias específicas e adjacentes.

Patentes depositadas nos escritórios de marcas e patentes são classificadas de acordo com a Classificação Internacional de Patentes, do inglês International Patent Classification (IPC). Além dessa taxonomia, estes documentos também são classificados de acordo com taxonomias próprias de cada escritório, sendo os mais difundidos o americano United States Patent Classification (USPC), o europeu European Patent Classification (ECLA) e o japonês Japanese File Index and F-Term (FI/F-Term).

A taxonomia internacional (IPC) e a americana (USPC) apresentam classes específicas para a área de Bioinformática. A classificação americana específica para Bioinformática foi criada em 1999 (USPTO, 2012), enquanto a IPC é mais recente e foi criada em 2010 (WIPO, 2010a). Até a criação das classes de Bioinformática, os examinadores classificavam os depósitos de acordo com classes com a descrição mais próxima. Com a definição da classificação específica, essas patentes foram reclassificadas. O presente trabalho aborda a classificação americana de patentes de bioinformática, uma vez que a coleção utilizada nos experimentos foi obtida no site do USPTO.

A taxonomia USPC divide as diferentes tecnologias em classes e cada classe é subdividida em subclasses, de maneira a separar os diferentes processos, estruturas e funcionalidades relacionados à cada tecnologia. A classificação de uma patente é definida por um identificador chamado símbolo de classificação ou classificação USPC, o qual é composto pelos códigos alfanuméricos da classe e da subclasse. Por exemplo, na classificação 702/20 
Tabela 1: Exemplo de classificação USPC

\begin{tabular}{|l|l|}
\hline Classificação & Descrição \\
\hline Classe 702 & Processamento de Dados: medição, calibração ou testes \\
\hline Subclasse 01 & Sistemas de medição em ambiente específico \\
\hline Subclasse 19 & Biologia e bioquímica \\
\hline Subclasse 20 & Sequenciamento genético \\
\hline
\end{tabular}

de Bioinformática o código 702 denota a classe que agrupa tecnologias de Processamento de Dados: medidas, calibrações ou testes e o código 20 denota a subclasse Sequenciamento genético. A subclasse que compõe o símbolo de classificação pode estar subordinada à outras subclasses. No exemplo citado, a subclasse 20 está subordinada à subclasse 19, que denota o Processamento de dados biológicos e bioquímicos. A subclasse 19, por sua vez, está subordinada à subclasse 1, que denota Sistemas de medida em ambiente específico (USPTO, 2005). A Tabela 1 ilustra o exemplo.

No escritório americano, as análises de patentes são efetuadas por unidades internas chamadas Art Unit. Cada Art Unit é responsável pelas análises de patentes de uma determinada área, assim cada unidade também é responsável pelas classes correspondentes à sua área tecnológica. A unidade responsável pela área de Bioinformática é a Art Unit 1631, conforme divulgado em (USPTO, 2012). Esta unidade é responsável por cinco subclasses, sendo três pertencentes à classe 702, que agrupa tecnologias relacionadas à Processamento de Dados: medição, calibração ou testes e duas subclasses pertencentes à classe 703, que agrupa tecnologias relacionadas à Processamento de Dados: design estrutural, modelagem, simulação e emulação. A Tabela 2 ilustra as subclasses, seus títulos e hierarquias. No Apêndice A são as definições de cada classe e subclasse são detalhadas na sua linguagem original, a qual é o inglês.

Existem dois tipos de classificação USPC: obrigatória (mandatory) e arbitrária (discretionary). De acordo com (USPTO, 2005), cada reivindicação de uma patente deve receber

\begin{tabular}{|c|c|c|c|c|c|}
\hline \multirow[t]{5}{*}{702} & \multicolumn{4}{|c|}{ Processamento de dados: medições, calibrações ou testes } & \multirow{3}{*}{$\begin{array}{c}\text { Classes de } \\
\text { Bioinformática } \\
702 / 19\end{array}$} \\
\hline & \multirow[t]{4}{*}{1} & \multicolumn{3}{|c|}{ Sistemas de medição em ambiente específico } & \\
\hline & & \multirow[t]{3}{*}{19} & \multicolumn{2}{|c|}{ Biológico ou Bioquímico } & \\
\hline & & & 20 & Determinação de sequência de genes & $702 / 20$ \\
\hline & & & & Contagem de células ou análise da forma ou tamanho & $702 / 21$ \\
\hline \multirow[t]{4}{*}{703} & \multicolumn{4}{|c|}{ Processamento de dados: projeto estrutural, modelagem, simulação e } & \\
\hline & \multirow[t]{3}{*}{6} & \multicolumn{3}{|c|}{ Simulação de sistemas ou dispositivos não-elétricos } & \\
\hline & & 11 & Bio & gico ou Bioquímico & 703/11 \\
\hline & & 12 & Quí & & $703 / 12$ \\
\hline
\end{tabular}

Tabela 2: Classes USPC de Bioinformática e hierarquias (USPTO, 2012). 
uma classificação para que o documento seja rastreável por pesquisas classificadas. Dessa maneira, todas as patentes recebem, ao menos, uma classificação obrigatória. Classificações obrigatórias são subdivididas em classificação original, do inglês original classification (OR) e classificações de referência cruzada, do inglês cross-reference (XR). A OR identifica o documento e é obtida da classificação atribuída à reivindicação principal da patente. As XR são obtidas das classificações atribuídas às reivindicações secundárias. As classificações do tipo arbitrária (XD) também são de referência cruzada e são atribuídas às patentes pelas unidades de análise, que desejam adicionar informações específicas que auxiliam nas pesquisas classificadas.

O processo de classificação de patentes demanda que especialistas de domínio realizem análises extensivas e apuradas de cada documento. Os órgãos de análise têm realizado grandes esforços para classificar patentes da maneira mais ágil, correta e imparcial possível. Entretanto, esta é uma atividade demorada e sujeita à variações de análise devido à interferência humana, ou seja, ao julgamento individual de cada examinador. Nesse contexto, ferramentas computacionais capazes de assistir esse processo, fornecendo resultados de maneira mais rápida e sistemática, têm despertado o interesse de profissionais da área de patentes e inventores.

\subsection{Patentes Brasileiras}

A história das patentes no Brasil se inicia após a chegada da família real portuguesa ao país. Com a instalação da corte portuguesa no Brasil, era necessário promover o desenvolvimento econômico e industrial da colônia. Assim, entre as medidas tomadas por D. João VI destacam-se a liberação da atividade industrial em 1808 e a criação da primeira legislação patentária do Brasil em 1809, sendo a quarta no mundo, posterior apenas às legislações de Estados Unidos, Inglaterra e França (INPI, 2011c) (DOLABELLA, 2009).

Em mais um esforço do governo brasileiro em promover o desenvolvimento econômico e industrial do país, em 1970, por meio da lei 5.648, foi criada como autarquia federal vinculada ao Ministério do Desenvolvimento, Indústria e Comércio Exterior (MDIC) o Instituto Nacional de Propriedade Industrial (INPI), o qual tem a responsabilidade de (i) tratar de todos os assuntos ligados à propriedade industrial, (ii) aplicar as normas de propriedade industrial dentro do país, (iii) pronunciar-se sobre tratados, convenções, convênios e acordos da área, (iv) conceder patentes, (v) averbar contratos de transferência 


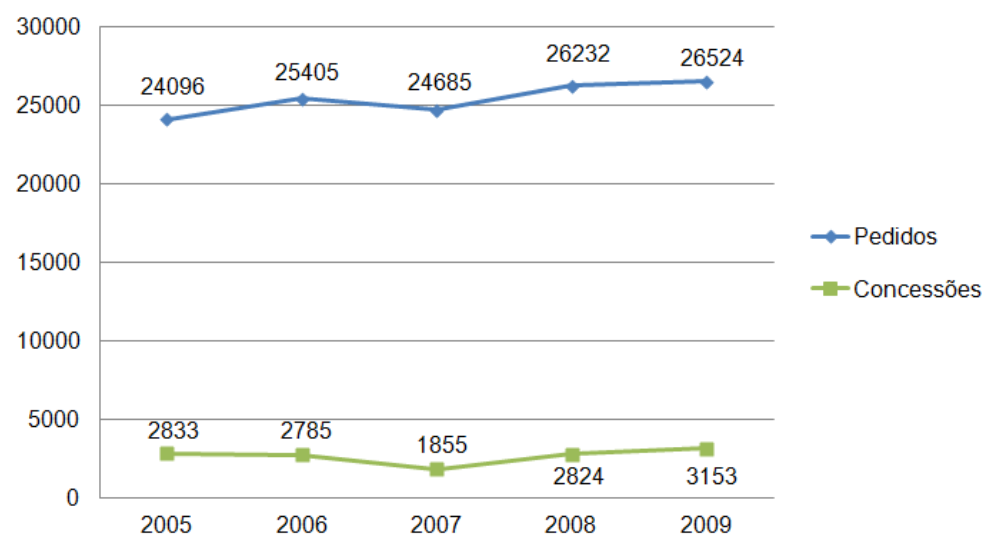

Figura 1: Pedidos e concessões no INPI entre 2005 e 2009 (Elaborado de acordo com (INPI, 2010b) (INPI, 2009)). Acessado em Julho/2013.

de tecnologia e de franquia empresarial e (vi) registrar marcas, programas de computador, desenho industrial, indicações geográficas e topografia de circuitos integrados. Nesse contexto, o INPI passou a ser o escritório oficial de análise e concessão de patentes no Brasil (INPI, 2011c).

Conforme apresentado na Figura 1, o número de pedidos e concessões de patentes no Brasil cresceu ligeiramente desde 2007. Entretanto, segundo pesquisas recentes, esse crescimento não é compatível com o crescimento econômico apresentado pelo Brasil nos últimos anos. Segundo a FAPESP, o Brasil também não apresentou evolução significativa no ranking de países depositantes de patentes comparativamente a outros países (FAPESP, 2010). Os autores de (FAPESP, 2010) analisaram a quantidade de depósitos, cujos inventores residiam no Brasil, e efetuados no escritório americano entre 1974 e 2006 e verificaram que o Brasil oscilou entre a $25^{\mathrm{a}}$ e $29^{\mathrm{a}}$ posição na classificação dos países que mais depositaram pedidos no USPTO. Apesar do crescimento em números absolutos de depósito, que passou de 44 em 1974 para 341 em 2006, o Brasil permanece na 29a posição desde 1998 e não conseguiu acompanhar a evolução de outros países que até 1974 permaneciam atrás do Brasil e em 2006 passaram à frente na classificação, dos quais citam-se a China que atingiu a $10^{\mathrm{a}}$ posição, a Índia que figura na $17^{\mathrm{a}}$, a Coréia do Sul na $4^{\mathrm{a}}$ e a Malásia que atingiu a $28^{\mathrm{a}}$ posição.

Reconhecendo a importância das patentes para o desenvolvimento tecnológico e econômico do Brasil, o Ministério da Ciência, Tecnologia e Inovação (MCTI) tem realizado mudanças em suas políticas visando aperfeiçoar os mecanismos de incentivo a pesquisa e inovação. Nos últimos anos, o órgão tem criado programas de incentivo, linhas de financiamento, aprimorado leis e aumentado os incentivos fiscais para que, não somente 
entidades públicas (hoje responsáveis por $\frac{2}{3}$ dos pedidos), mas também empresas privadas possam desenvolver mais produtos inovadores e, consequentemente, obter mais patentes. Além dessas ações, o governo tem investido no INPI para agilizar o processo de análise e concessão de patentes. De acordo com o boletim estatístico de 2010, o número de examinadores passou de 112 em 2005 para 273 em 2010. Esse aumento já reflete no número de exames realizados os quais eram 9.643 em 2005 e passaram para 16.878 em 2009 (INPI, 2010a).

Ao estudar o contexto brasileiro, os autores de (FAPESP, 2010) analisaram a interação entre as áreas tecnológicas e as áreas científicas às quais as patentes depositadas no USPTO estão relacionadas. Os autores verificaram o aumento das interações ciência e tecnologia entre os anos de 1974 e 2006 e, a partir dessas análises, afirmaram que os trabalhos científicos têm aumentado sua contribuição para o desenvolvimento de novas tecnologias, o que vem tornando o desenvolvimento tecnológico mais dependente do desenvolvimento científico.

A Figura 2 apresenta uma comparação entre a quantidade de depósitos de pedidos de patentes dos Estados Unidos e do Brasil no escritório americano no ano de 2006. O eixo denominado $\mathrm{OST}^{3}$ (Observatoire des Sciences et Techniques) identifica os códigos das áreas tecnológicas às quais as patentes estão ligadas. No eixo $\mathrm{ISI}^{4}$ (Institute for Scientific Information) estão identificados os códigos das áreas científicas que as patentes correspondem. O eixo vertical apresenta a quantidade de depósitos de patente correspondente a cada par de interação ciência-tecnologia.

Analisando a Figura 2, percebem-se diferenças entre Estados Unidos e Brasil. Os americanos apresentam uma matriz preenchida em quase sua totalidade, ou seja, os desenvolvimentos tecnológico e científico estão fortemente ligados, a escala de quantidade de depósitos por par de interação chega próximo dos 100.000 pedidos e o pico se encontra entre as áreas tecnológicas da Tecnologia da Informação (OST 4) e a área científica da Engenharia Eletrônica (ISI 3). Em contrapartida, o Brasil apresenta um perfil distinto com uma matriz não totalmente preenchida e demonstrando maior atividade nos subdomínios tecnológicos de Semicondutores (OST 5), Óticos (OST 6), Análise, Medições e Controle (OST 7), Engenharia Médica (OST 8), Química Orgânica (OST 9), Química Macromolecular (OST 10) e Biotecnologia (OST 12) interagindo com todas as áreas científicas abordadas na pesquisa. A escala do gráfico brasileiro é inferior à americana e atinge

\footnotetext{
${ }^{3}$ Organização francesa de estudos sobre atividade tecnológica, científica e inovativa (http://www.obsost.fr/en.html).

${ }^{4}$ Instituto americano ligado à agência de informações Thomson Reuters e especializado em indexação de citações científicas (http://isiwebofknowledge.com/).
} 

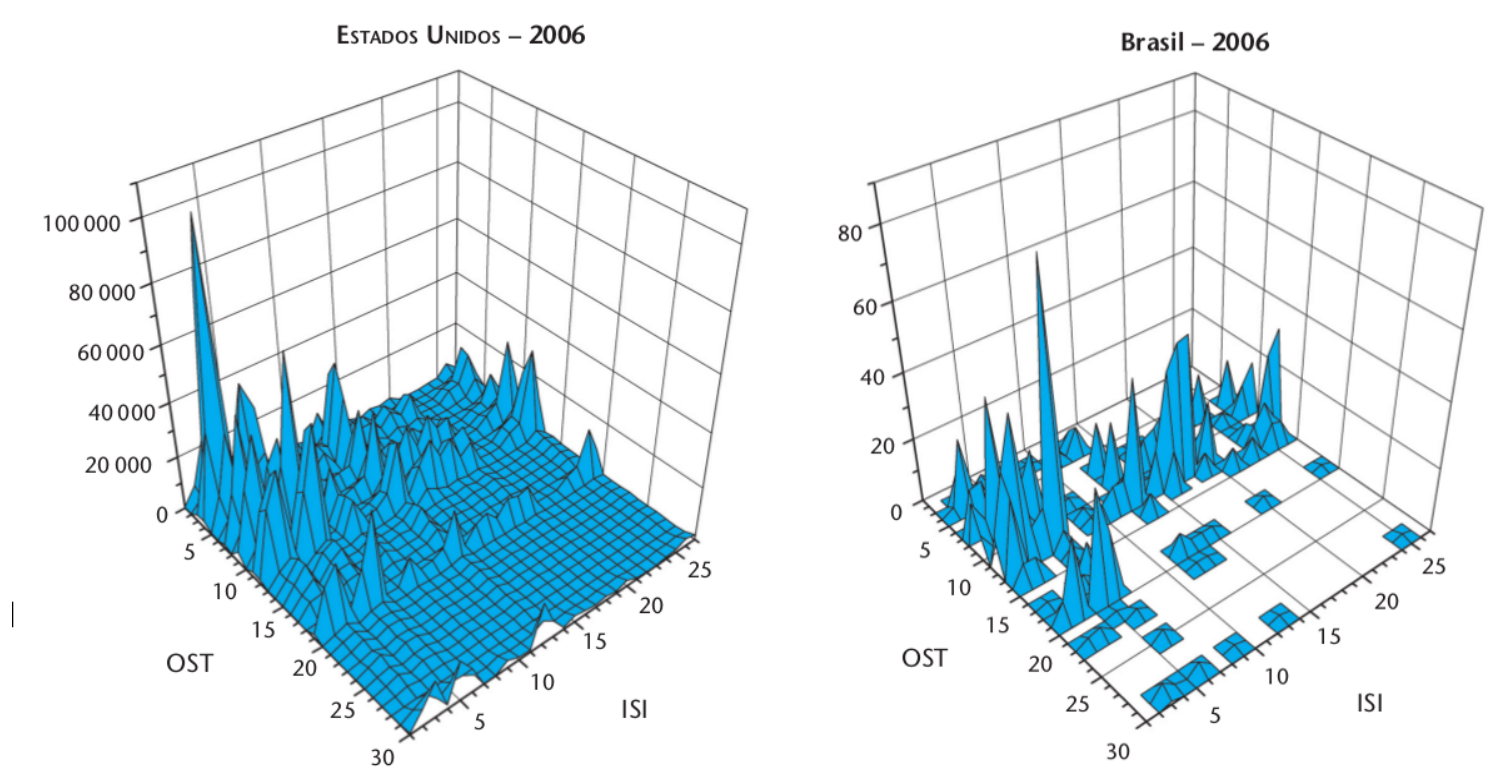

Figura 2: Matrizes de interação entre ciência e tecnologia dos Estados Unidos e Brasil em 2006 (RIBEIRO et al., 2010). Acessado em Julho/2013.

em torno de 60 pedidos. O pico apresentado no gráfico brasileiro identifica a interação entre a área tecnológica da Biotecnologia (OST 12) e a área científica da Engenharia Química e Química Orgânica (ISI 6).

A partir dessas comparações, (FAPESP, 2010) sugere que o desenvolvimento tecnológico de um país deve ser amparado por uma estrutura sólida de ciências e engenharias. Com o aumento da contribuição de áreas científicas para o desenvolvimento de novas tecnologias, o desenvolvimento científico torna-se ponto-chave para o aumento do número de patentes de um país.

Além da interação ciência-tecnologia identificada em (FAPESP, 2010), o mesmo trabalho analisa os subdomínios tecnológicos líderes no Brasil em termos de quantidade de depósitos de patentes do tipo Modelo de Utilidade (MU) e Patentes de Invenção (PI), entre os anos de 1980 e 2005. A Figura 3 indica o domínio das patentes de Modelo de Utilidade nos subdomínios tecnológicos mais tradicionais como Consumo das Famílias, Manutenção e Gráfica, Construção Civil e Transportes. A partir do subdomínio da Engenharia Médica, o comportamento começa a se alterar e o número de depósitos de PI's se aproxima do número de MU's. Ao abordar subdomínios relacionados a paradigmas tecnológicos mais recentes, como é o caso das áreas de Telecomunicações, Farmacêutica-Cosméticos, Produtos Agrícolas e Alimentares, Informática, Química Macromolecular e Biotecnologia, os autores destacam uma inversão no comportamento, visto que os depósitos de patentes do tipo MU diminuem e as patentes do tipo PI passam a predominar. Segundo (RICHARDS, 2010), o aumento no número de depósitos do tipo PI, frente ao número de depósitos do 


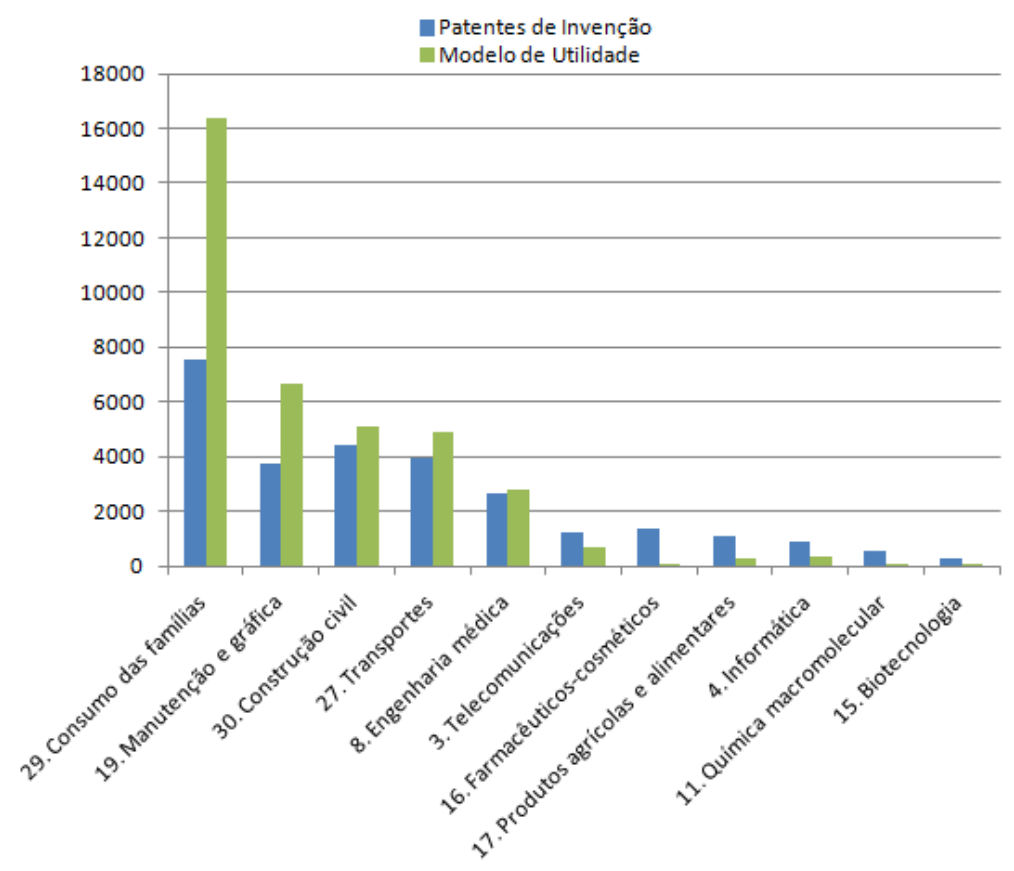

Figura 3: Depósito de patentes no INPI de residentes no Brasil, por tipo de patente, segundo subdomínios tecnológicos do OST - 1980-2005 (FAPESP, 2010). Acessado em Julho/2013.

tipo MU, caracteriza o aumento da atividade inventiva em determinado país. Patentes do tipo MU requerem menos atividade inventiva e menos investimentos que patentes do tipo PI, uma vez que os Modelos de Utilidade se caracterizam por melhorias em invenções existentes.

A partir das análises apresentadas, notam-se os avanços brasileiros referentes à propriedade intelectual e industrial no setor de Biotecnologia, seja no aumento de interações com diversas áreas científicas para apoiar o desenvolvimento de novas tecnologias ou pelo crescimento no número de depósitos de patentes de invenção. Entretanto, segundo a FAPESP, os avanços conquistados ainda são pequenos se comparados ao potencial apresentado pelo Brasil, principalmente nos últimos anos que o país tem apresentado crescimento econômico significativo. Para o país sair da condição de estagnação relativa à outros países no setor de propriedade intelectual, a qualidade das patentes brasileiras deve ser melhorada e as oportunidades trazidas por tecnologias emergentes como a Biotecnologia, Nanotecnologia e novas fontes de energia devem ser mais exploradas (FAPESP, 2010).

Vislumbrando essas oportunidades, o governo brasileiro vem atuando para estimular o crescimento do setor de Biotecnologia. Por meio do INPI, o governo tem realizado palestras e cursos pelo país para difundir orientações sobre área, como efetuar pedidos de patentes e quais a regras e aspectos específicos que são exigidos para patentes de Biotec- 
nologia ${ }^{5}$. O INPI esteve presente no Bio International Convention, realizado nos Estados Unidos, para divulgar internacionalmente o setor de Biotecnologia brasileiro e estimular os investimentos na área ${ }^{6}$. Por meio do Ministério da Ciência, Tecnologia e Inovação, o governo tem promovido programas de apoio a empresas do setor como GENOPROT ${ }^{7}$ (Rede Integrada de Estudos Genômicos e Proteômicos) que visa apoiar pesquisas sobre inovações em estudos genômicos e proteômicos, RENORBIO ${ }^{8}$ (Programa Rede Nordeste de Biotecnologia) cujo objetivo é apoiar o desenvolvimento da área no nordeste brasileiro e o Programa Biotech ${ }^{9}$, o qual visa promover o desenvolvimento da Biotecnologia no Mercosul e aumentar a competitividade dessa comunidade frente ao mercado internacional.

\subsection{Requisitos e Roteiro para o Pedido de Patente no Brasil}

Apesar das diferenças regionais brasileiras entre as legislações de patentes, existem elementos comuns. Em geral, produtos, processos ou ambos podem ser patenteados. As patentes podem se referir a uma criação específica ou a um conjunto delas, mas devem conter o mesmo princípio inventivo. No Brasil, as regras sobre patentes são amparadas pela lei 9.279 de 1996, chamada de Lei da Propriedade Industrial (LPI), pela lei 10.196 de 2001 e pelos atos normativos 127, 128 e 130 publicados em 1997. Assim como outros importantes escritórios de marcas e patentes, a legislação brasileira prevê três requisitos básicos para o registro de uma invenção (INPI, 2008).

O primeiro requisito para registro de invenção é a novidade, o qual determina que a invenção não tenha sido divulgada antes da data do pedido de patente, seja por uso ou apresentação textual ou oral, no Brasil ou no exterior. Citam-se como exemplos de divulgação painéis, palestras, defesas de teses, dissertações, artigos científicos, entre outros. No entanto, a legislação brasileira impõe uma exceção para este requisito. Caso a divulgação tenha sido efetuada até 12 meses antes da data do pedido, a invenção ainda é considerada como novidade no estado da técnica. Esse período de 12 meses é chamado de Período de Graça e varia de acordo com a legislação patentária de cada país. O segundo requisito diz respeito à atividade inventiva ou ato inventivo, ou seja, demonstrar que o trabalho desenvolvido não provém de uma dedução óbvia para um técnico no assunto. Por

\footnotetext{
${ }^{5}$ http://www.inpi.gov.br/noticias/inpi-da-orientacoes-na-area-de-Biotecnologia

${ }^{6}$ http://www.inpi.gov.br/noticias/inpi-ira-estimular-investimentos-em-Biotecnologia-no-brasil

${ }^{7}$ http://www.mcti.gov.br/index.php/content/view/5680.html

${ }^{8}$ http://www.mcti.gov.br/index.php/content/view/12553.html

${ }^{9}$ http://www.mcti.gov.br/index.php/content/view/71874.html
} 
meio deste requisito, busca-se determinar a atividade intelectual inventiva e não apenas uma dedução lógica composta por elementos obtidos no estado da técnica. Por último, o terceiro requisito determina a aplicação industrial e a suficiência descritiva do invento, i.e., o invento deve ser passível de utilização comercial e sua descrição deve ser clara e objetiva, de maneira a permitir ser reproduzido por um técnico no assunto e em escala industrial (INOVAçãO, 2011) (INPI, 2008). Segundo (INPI, 2008), o termo industrial se refere às atividades pertencentes ao campo prático e útil, ou seja, atividades que remetem à operação de uma indústria, diferentemente de atividades artísticas que partem de um princípio abstrato.

Segundo o INPI, o roteiro para o depósito e concessão de uma patente deve começar a partir de uma consulta à Lei de Propriedade Industrial (LPI) e, em especial, aos artigos 10 e 18, a fim de identificar uma criação patenteável. Em seguida, é necessário definir a patente como invenção (PI) ou modelo de utilidade (MU). Conforme citado anteriormente, a invenção abrange produtos e processos que sejam novos no estado da técnica, que possuem atividade inventiva associada e tenham aplicação industrial. Assim, o INPI sugere aos interessados na concessão que, antes do pedido formal, efetuem buscas amplas em diversas fontes como bases de informações de patentes nacionais e internacionais, revistas especializadas e publicações técnicas e científicas, com o objetivo de certificar que a criação a ser depositada ainda não foi publicada (INPI, 2008).

Após a etapa de pesquisas e definições preliminares, inicia-se o pedido formal de concessão da patente. Os procedimentos e documentos que devem ser preenchidos nesta etapa são descritos no Ato Normativo do INPI número 127/97. No entanto, de maneira geral, são solicitados o preenchimento do requerimento de concessão, relatório descritivo, descrição das reivindicações, desenhos (em casos específicos), resumo e comprovante de pagamento da taxa de depósito. De todas as informações prestadas nesses documentos, as reivindicações devem ser elaboradas cuidadosamente já que, em caso de disputas judiciais, este texto é que define os direitos do titular. Caso esse texto seja mal elaborado, o pedido de patente pode ser invalidado (INPI, 2008).

Com todos os documentos devidamente preenchidos, o requerente pode depositar o pedido formalmente. Em posse da documentação, o INPI efetua uma análise preliminar para garantir a conformidade do pedido com a LPI e, após essa análise, é gerado um pedido devidamente numerado. Caso haja interesse em efetuar o pedido em outros países, o requerente pode solicitar o depósito pelo sistema PCT, do inglês Patent Cooperation Treaty, o qual aumenta o prazo, de 12 para 30 meses, para depósito da patente em questão 
em países signatários do PCT. Após a publicação, o requerente tem de 18 a 36 meses da data de depósito para pedir o exame de sua patente. Ao final desse processo, caso o pedido seja deferido, a carta-patente é emitida. Esse documento certifica a concessão da patente no Brasil (INPI, 2008).

\subsection{Patentes de Bioinformática}

Segundo (MOUNT, 2001), a Bioinformática é um campo multidisciplinar, relativamente novo e crescente, que surgiu da demanda por processamento do grande volume de dados biológicos gerados por pesquisas da área. A Bioinformática se utiliza de ferramentas computacionais, estatísticas e matemáticas para processar informações como sequências biológicas, genoma e prever as funções e estruturas de macromoléculas. (LESK, 2002) cita que os avanços na Bioinformática são devido aos avanços na área de ciência da computação. Algoritmos bem elaborados, estruturas de dados, técnicas de recuperação de informação em grandes bases de dados e engenharia de computação são consideradas importantes na análise e resolução de problemas biológicos.

De acordo com (HULTQUIST et al., 2002), a Bioinformática tem contribuído significativamente para o desenvolvimento de tecnologias inovadoras no campo da Biotecnologia. $\mathrm{O}$ setor de Bioinformática vem experimentando crescimentos anuais de investimento devido ao seu potencial de retorno econômico. Esse contexto tem motivado grandes empresas dos setores de Biotecnologia e Tecnologia da Informação a investirem em pesquisas em Bioinformática. Como consequência das disputas comerciais em busca de vantagem competitiva na área, o número de pedidos de patentes de tecnologias relacionadas à Bioinformática também têm crescido (HULTQUIST et al., 2002).

Segundo (GATTO, 2001), as patentes de Bioinformática são compostas por categorias de diferentes áreas. O autor lista as classes da taxonomia do USPTO que comumente estão relacionadas às patentes de Bioinformática. Entre as classes citadas estão: Processamento de Dados, Bancos de Dados e Processamento de Documentos, Processamento de Dados Médicos, Biológicos e Bioquímicos, Sequenciamento de Genes e Análise de Imagens de Aplicações Biomédicas e de Leitura de Padrões de DNA e RNA. (GATTO, 2001) analisa os números de patentes dessas classes que foram concedidas entre 1996 e 2001 e demonstra o crescimento do setor. Em 1996 foram 72 concessões de patentes relacionadas à Bioinformática, em 1998 o total de concessões subiu para 187 e em 2001 atingiu 349 pedidos concedidos (GATTO, 2001). 
De acordo com (GATTO, 2001), as patentes de Bioinformática apresentam alguns desafios. O primeiro desafio está relacionado à multidisciplinaridade da Bioinformática. Essa caraterística torna necessária a participação de profissionais que conheçam de Tecnologia da Informação e Biotecnologia ou a formação e participação de equipes multidisciplinares para tarefas de elaboração e análise de patentes. Outro desafio apontado pelo autor é a diversidade de modelos de negócio que são criados para explorar as tecnologias de Bioinformática desenvolvidas. Entre esses modelos, citam-se licenciamento de dados, licenciamento de software, venda de equipamentos de teste, entre outros. Essa diversidade de modelos demanda a cooperação entre profissionais de diferentes áreas, de maneira a aliar o conhecimento técnico sobre a nova tecnologia ao seu potencial retorno econômico. Assim, se define o modelo de negócio mais adequado e as reivindicações podem ser mais abrangentes e garantir maior proteção à tecnologia que está sendo patenteada (GATTO, 2001). 


\section{Classificação Automática de Textos}

Neste capítulo são abordados os conceitos utilizados no desenvolvimento do sistema de busca guiada de patentes de bioinformática apresentado pelo presente trabalho. Na Seção 3.1 são explicados os conceitos de classificação automática de textos único e multirrótulo. Nas subseções seguintes são descritos conceitos aplicados no módulo de classificação automática de patentes.

\subsection{Conceitos Gerais}

Uma das áreas mais estudadas de mineração de dados e de texto é a classificação ou categorização automática. De maneira geral, as atividades nessa área visam classificar novos dados baseando-se em conjuntos de dados de treinamento cujos rótulos já são conhecidos. De acordo com (MONARD; BARANAUSKAS, 2003), um algoritmo de aprendizado, também chamado de indutor, recebe como entrada um conjunto de exemplos de treinamento e apresenta como saída um classificador, que terá a capacidade de determinar qual a classe de novos exemplos ainda não rotulados. Devido à esse comportamento, na área de Aprendizado de Máquina diz-se que a classificação automática integra o grupo de tarefas de aprendizado supervisionado (MONARD; BARANAUSKAS, 2003).

Como se pode observar na Tabela 3, um conjunto de treinamento apresenta $n$ instâncias $T, m$ atributos $X$ e uma classe associada $Y$. Cada instância de treinamento $T$ possui um valor $x$ correspondente para cada atributo $X$ e uma função $y$ que classifica o exemplo de acordo com os valores dos atributos. Formalmente, cada instância é uma tupla $T_{i}=\left(x_{i 1}, x_{i 2}, \ldots, x_{i m}, y_{i}\right)=\left(\vec{x}_{i}, y_{i}\right)$, onde $i=(1,2, \ldots, n), x_{i m}$ é o valor do $m$-ésimo atributo $X_{m}$ da instância $T_{i}$ e $y_{i}=f\left(\vec{x}_{i}\right)$ a $i$-ésima função que classifica a instância $T_{i}$ de acordo com o vetor de atributos $\overrightarrow{x_{i}}$. Para avaliar o classificador, em geral divide-se o conjunto de instâncias de entrada do indutor em dois subconjuntos disjuntos, sendo um 
para treinamento e outro para teste.

Quando aplicada a textos, a Classificação Automática é denominada Categorização ou Classificação Textual, do inglês Text Categorization (TC) e tem como objetivo identificar tópicos ou assuntos aos quais determinados textos estão relacionados. Para este caso, cada instância dos conjuntos de treinamento e teste são documentos, os atributos são as palavras ou termos encontrados nos mesmos e os valores de cada atributo, dependendo da abordagem, podem ser as frequências de cada termo nos respectivos documentos ou um peso derivado das frequências, como o $t f-i d f$, apresentado no Capítulo 4 . Com a crescente quantidade de documentos digitais disponíveis, a classificação automática de textos tem auxiliado na organização e facilitação do acesso a esses documentos. Atualmente, a TC tem sido aplicada em vários contextos como a indexação de textos, personalização de anúncios comerciais, filtragem de mensagens indesejadas (spam), categorização de páginas web, classificação de patentes, entre outros (FELDMAN; SANGER, 2006).

A aplicação da TC é efetuada por meio de duas abordagens principais: Engenharia do Conhecimento, do inglês Knowledge Engineering (KE) e Aprendizado de Máquina, do inglês Machine Learning (ML). Na primeira abordagem, a classificação é dada por sistemas que integram ferramentas computacionais e conhecimento humano especializado de forma declarativa ou por meio de regras procedurais de classificação. Em contrapartida, a segunda abordagem modela um sistema classificador de acordo com exemplos classificados anteriormente. Pesquisas recentes tem demonstrado que a KE é a abordagem mais eficiente (FELDMAN; SANGER, 2006). Entretanto, a manutenção de sistemas de classificação automática de textos com KE demanda grande esforço de especialistas para criar e manter as regras de conhecimento. Assim, o Aprendizado de Máquina tem sido a abordagem mais utilizada atualmente por considerar apenas conjuntos de dados pré-classificados, os quais podem demandar menos esforço para serem mantidos (FELDMAN; SANGER, 2006).

Os sistemas de categorização automática de textos podem ser diferenciados por aspectos como o foco da análise ao efetuar a classificação (no documento ou na classe), se a classificação é automática ou semi-automática e quanto a quantidade de classes que o

\begin{tabular}{llllll} 
& $X_{1}$ & $X_{2}$ & $\ldots$ & $X_{m}$ & $Y$ \\
\hline$T_{1}$ & $x_{11}$ & $x_{12}$ & $\ldots$ & $x_{1 m}$ & $y_{1}$ \\
$T_{2}$ & $x_{21}$ & $x_{22}$ & $\ldots$ & $x_{2 m}$ & $y_{2}$ \\
$\ldots$ & $\ldots$ & $\ldots$ & $\ldots$ & $\ldots$ & $\ldots$ \\
$T_{n}$ & $x_{n 1}$ & $x_{n 2}$ & $\ldots$ & $x_{n m}$ & $y_{n}$
\end{tabular}

Tabela 3: Conjunto de treinamento apresentado como entrada a um algoritmo de treinamento único rótulo. (MONARD; BARANAUSKAS, 2003). 
mesmo atribui a cada documento. (FELDMAN; SANGER, 2006).

No primeiro aspecto, classificadores podem trabalhar basicamente de duas maneiras: (i) dado um documento, o sistema define a qual ou quais classes o mesmo pertence (Document-Pivoted, empregada quando todas as classes já estão bem definidas) e (ii) dada uma classe, o sistema aponta quais documentos pertencem a essa categoria (CategoryPivoted, utilizada quando a coleção de documentos já está definida) (FELDMAN; SANGER, 2006). No presente trabalho foi utilizada a abordagem Document-Pivoted, pois as classes de Bioinformática do USPTO são conhecidas e bem estabelecidas.

Sobre o aspecto de automaticidade, a categorização pode ser completamente automática (Hard Categorization), ou seja, o sistema determina quais documentos pertencem a quais classes. Ou a categorização pode ser semi-automática, ou seja, o sistema sugere uma lista de possíveis classes, ordenadas pelo grau de similaridade, para cada documento processado. Essa técnica é denominada Soft ou Ranking Categorization. Para este trabalho optou-se pela segunda abordagem (Ranking Categorization), pois o classificador desenvolvido será utilizado como um guia que sugerirá ao usuário as classes às quais o documento consultado apresenta maior grau de similaridade.

Sobre o terceiro aspecto, classificadores que identificam apenas uma classe por documento são denominados único rótulo ou single-label e os que definem mais de uma classe para cada instância são denominados multirrótulo ou multilabel(FELDMAN; SANGER, 2006). Visando utilizar não somente as classes obrigatórias, mas também as classes arbitrárias (complementares) das patentes, optou-se por utilizar algoritmos de classificação multirrótulo para o desenvolvimento do indutor deste trabalho. Na Seção 3.1.1, as abordagens de classificação único rótulo e multirrótulo são detalhadas e comparadas.

\subsubsection{Classificação Único Rótulo e Multirrótulo}

De acordo com (TSOUMAKAS et al., 2011a), a classificação único rótulo é dada pelo aprendizado induzido a partir de exemplos classificados apenas por um rótulo $\lambda$ que pertence à um conjunto de rótulos $L$ de tamanho $M$, sendo $M>1$. Assim, o classificador atribuirá apenas um rótulo para cada nova instância analisada. Os conjuntos de tamanho $M=2$ são chamados de problemas de classificação binária. Se $M>2$ os problemas são chamados de problemas multiclasse.

O $k$-NN original é um dos mais simples e bem difundidos algoritmos de classificação único rótulo baseado em instâncias. Esse algoritmo compara cada nova instância a ser 
classificada com os documentos de sua coleção de treinamento. A classe que será atribuída ao novo documento é definida pelos $k$ documentos mais próximos (similares). De acordo com (LUPU et al., 2011), esse algoritmo apresenta bom desempenho com um número reduzido de classes, como é o caso do presente trabalho para as classes de Bioinformática.

O SVM tem como origem a teoria do aprendizado estatístico e sua utilização para classificação textual único rótulo foi proposta por (JOACHIMS, 1998). No contexto de classificação textual, o SVM considera cada palavra ou termo como uma dimensão em um espaço e cada documento da coleção é considerado um ponto no mesmo espaço. O algoritmo projeta planos entre os conjuntos de documentos, visando separar documentos de classes distintas. Sua versão mais simples é aplicada a problemas lineares de duas classes. Porém, existem variações que permitem a utilização do algoritmo em problemas não-lineares e multi-classes (LUPU et al., 2011) (CORTES; VAPNIK, 1995). Segundo (JOACHIMS, 1998), o SVM é robusto ao overfitting, não necessita seleção de atributos e apresenta bom desempenho ao lidar com bases de dados de alta dimensionalidade. Essas características tornam o SVM vantajoso na classificação textual, uma vez que problemas de categorização de textos possuem alta dimensionalidade e a maioria são linearmente separáveis (JOACHIMS, 1998).

O Naive Bayes Multinomial (NBM) é um algoritmo único rótulo probabilístico de complexidade computacional linear, baseado no Teorema de Bayes e consiste em uma variação do Naive Bayes (NB). O NBM é comumente utilizado na classificação de textos, especialmente sob o modelo bag of words, pois permite processar os pesos atribuídos à cada termo de índice (Modelo Vetorial). Enquanto o original NB trabalha apenas com a existência ou não de cada termo em cada documento (Modelo Booleano) (WITTEN et al., 2011). Esse classificador calcula a probabilidade de cada conjunto de termos de índice relativa a cada classe e define uma distribuição multinomial para cada documento por um vetor de probabilidades. O algoritmo NB também é utilizado na classificação de patentes (LUPU et al., 2011).

Segundo (SHEN et al., 2004), erros de classificação geralmente acontecem devido à sobreposição das características que identificam as classes, ou seja, quando os atributos das instâncias se confundem e podem ser representativos tanto para uma classe quanto para outra ao mesmo tempo. Existem casos em que classificadores separam essas classes eficientemente com uma margem de erro aceitável. Entretanto, ao classificar instâncias multirrótulo, o erro de classificação é maior e a separação não é eficiente, pois é uma característica das instâncias pertencerem à um subconjunto de classes $Y \subseteq L$ (TSOUMAKAS 


\begin{tabular}{ccl} 
Exemplo & Atributos & Rótulos \\
\hline 1 & $\overrightarrow{x_{1}}$ & $Y_{1}=\left\{\lambda_{1}, \lambda_{4}\right\}$ \\
2 & $\overrightarrow{x_{2}}$ & $Y_{2}=\left\{\lambda_{3}, \lambda_{4}\right\}$ \\
3 & $\overrightarrow{x_{3}}$ & $Y_{3}=\left\{\lambda_{1}\right\}$ \\
4 & $\overrightarrow{x_{4}}$ & $Y_{4}=\left\{\lambda_{2}, \lambda_{3}, \lambda_{4}\right\}$
\end{tabular}

Tabela 4: Exemplo de um conjunto de treinamento multirrótulo (TSOUMAKAS et al., 2010).

et al., 2011a). Nos trabalhos de (SHEN et al., 2004) e (TSOUMAKAS et al., 2011a) são citados exemplos de problemas multirrótulo nas áreas de classificação textual, imagens, diagnósticos, genética, entre outras.

Assim como nos classificadores único rótulo, indutores de classificadores multirrótulo utilizam um conjunto de exemplos pré-classificados de treinamento para induzir o aprendizado. Contudo, a classificação multirrótulo se diferencia pelo número de rótulos a serem preditos de cada novo exemplo. Segundo (TSOUMAKAS et al., 2011a), as abordagens de aprendizado multirrótulo são divididas em dois grupos, sendo (i) métodos de transformação do problema e (ii) métodos de adaptação de algoritmos. Essas duas abordagens são detalhadas nas subseções seguintes. Para a análise de ambas abordagens, (TSOUMAKAS et al., 2010) descreve formalmente o conjunto de rótulos como $L=\left\{\lambda_{\mathrm{j}}: j=1 \ldots q\right\}$ e o conjunto de exemplos de treinamento como $D=\left\{\left(\overrightarrow{x_{i}}, Y_{i}\right), i=1 \ldots m\right\}$, onde $\overrightarrow{x_{\mathrm{i}}}$ é o vetor de atributos e $Y_{i}$ um subconjunto de $L$.

\subsubsection{Transformação do Problema}

Esse grupo de métodos concentra técnicas que transformam um problema multirrótulo em um ou mais problemas único rótulo, de maneira a aplicar métodos já conhecidos e mais difundidos do aprendizado single-label. A Tabela 4 é utilizada como base para ilustrar os exemplos de métodos de transformação de problemas. Nessa tabela são exibidas quatro instâncias com seus respectivos vetores de atributos $\vec{x}$ e classes $Y$. Como as transformações afetam apenas as instâncias e o conjunto de classes, nas tabelas de resultados são exibidas apenas duas colunas correspondentes à esses dados (TSOUMAKAS et al., 2010).

Inicialmente (TSOUMAKAS et al., 2010) apresenta seis métodos de transformação considerados mais simples. A primeira abordagem citada é a transformação por cópia, na qual cada instância $\left(\overrightarrow{x_{\mathrm{i}}}, Y_{i}\right)$ é substituída pelo número de cópias correspondentes à quantidade de rótulos $\left|Y_{i}\right|$. Cada novo exemplo é representado por $\left(\overrightarrow{x_{\mathrm{j}}}, \lambda_{j}\right), \operatorname{com} j=\{1,2, \ldots$, $\left.\left|Y_{i}\right|\right\}$ e $\lambda_{j} \in Y_{i}$. O item $(a)$ da Tabela 5 ilustra a transformação por cópia.

O segundo método apresentado é uma variação da transformação por cópia chamada 


\begin{tabular}{|c|c|}
\hline Ex. & Rót. \\
\hline $1 \mathrm{a}$ & $\lambda_{1}$ \\
$1 \mathrm{~b}$ & $\lambda_{4}$ \\
$2 \mathrm{a}$ & $\lambda_{3}$ \\
$2 \mathrm{~b}$ & $\lambda_{4}$ \\
3 & $\lambda_{1}$ \\
$4 \mathrm{a}$ & $\lambda_{2}$ \\
$4 \mathrm{~b}$ & $\lambda_{3}$ \\
$4 \mathrm{c}$ & $\lambda_{4}$ \\
\hline \multicolumn{2}{|c|}{$(a)$} \\
\hline
\end{tabular}

\begin{tabular}{|c|c|c|}
\hline Ex. & Rót. & Peso \\
\hline $1 \mathrm{a}$ & $\lambda_{1}$ & 0.50 \\
$1 \mathrm{~b}$ & $\lambda_{4}$ & 0.50 \\
$2 \mathrm{a}$ & $\lambda_{3}$ & 0.50 \\
$2 \mathrm{~b}$ & $\lambda_{4}$ & 0.50 \\
3 & $\lambda_{1}$ & 1.00 \\
$4 \mathrm{a}$ & $\lambda_{2}$ & 0.33 \\
$4 \mathrm{~b}$ & $\lambda_{3}$ & 0.33 \\
$4 \mathrm{c}$ & $\lambda_{4}$ & 0.33 \\
\hline \multicolumn{3}{|c}{$(b)$} \\
\hline
\end{tabular}

\begin{tabular}{|c|c|}
\hline Ex. & Rót. \\
\hline 1 & $\lambda_{4}$ \\
2 & $\lambda_{4}$ \\
3 & $\lambda_{1}$ \\
4 & $\lambda_{4}$ \\
\hline
\end{tabular}

(c)

\begin{tabular}{|c|c|}
\hline Ex. & Rót. \\
\hline 1 & $\lambda_{1}$ \\
2 & $\lambda_{3}$ \\
3 & $\lambda_{1}$ \\
4 & $\lambda_{2}$ \\
\hline
\end{tabular}

(d)

\begin{tabular}{|c|c|}
\hline Ex. & Rót. \\
\hline 1 & $\lambda_{1}$ \\
2 & $\lambda_{4}$ \\
3 & $\lambda_{1}$ \\
4 & $\lambda_{3}$ \\
\hline
\end{tabular}

(e)

\begin{tabular}{|c|c|}
\hline Ex. & Rót. \\
\hline 3 & $\lambda_{1}$ \\
\hline
\end{tabular}

(f)

Tabela 5: Conjuntos de treinamento transformados em único rótulo. (a) cópia, $(b)$ cópia-com-peso, $(c)$ seleção-max, $(d)$ seleção-min, $(e)$ seleção-aleatória e $(f)$ descarte

(TSOUMAKAS et al., 2010).

cópia-com-peso, do inglês copy-weight, no qual é atribuído um peso $\frac{1}{\left|Y_{i}\right|}$ para cada nova cópia. O item (b) da Tabela 5 ilustra a transformação por cópia-com-peso.

Outro método citado em (TSOUMAKAS et al., 2010) é a seleção. Para se transformar o problema em único rótulo, nessa abordagem são selecionados exemplos de determinados rótulos, enquanto outros são descartados. Esse método possui três variações, sendo seleção-max apenas as classes com maior ocorrência na coleção dos escolhidos, seleção-min apenas os rótulos de menor ocorrência e seleção-aleatória seleciona as classes representativas aleatoriamente para compor o conjunto de treinamento. Os itens $(c),(d)$ e $(e)$ da Tabela 5 ilustram esses métodos respectivamente.

Por fim, na última transformação simples apresentada por (TSOUMAKAS et al., 2010), os exemplos com mais de um rótulo são descartados. Em casos como a classificação de patentes, onde a maior parte dos documentos possui classes complementares, essa abordagem pode comprometer seriamente o desempenho do classificador, pois pode eliminar todos os exemplos de treinamento de uma determinada classe. O item $(f)$ da Tabela 5 ilustra a transformação por descarte de exemplos multirrótulo.

Outra alternativa citada por (TSOUMAKAS et al., 2010) para transformar o problema é chamada de Label Powerset (LP), a qual consiste em criar novos rótulos baseados nas combinações de rótulos encontradas nos exemplos de treinamento e aplicar um algoritmo único rótulo. A Tabela 6 ilustra o conjunto de treinamento obtido com a aplicação desse método. O maior problema dessa abordagem é o grande aumento no número de rótulos, o que pode diminuir consideravelmente a quantidade de exemplos de treinamento de determinadas classes, prejudicando o desempenho do classificador.

Visando minimizar os problemas do Label Powerset, (TSOUMAKAS et al., 2011a) propõem 
um método baseado em LP chamado RAkEL (RAndom k-LabELsets). Esse algoritmo divide a grande quantidade de rótulos em conjuntos menores de classificadores LP, onde cada um deles é treinado com um subconjunto $k$ aleatório de rótulos. Na classificação de novos exemplos ainda não rotulados, o algoritmo RAkEL combina os resultados de todos os classificadores LP. Essa característica permite considerar a correlação entre os rótulos e evitar os problemas encontrados no algoritmo Label Powerset original.

\subsubsection{Adaptação de Algoritmos}

Diferentemente das técnicas de transformação de problemas, os métodos de adaptação de algoritmos não alteram os conjuntos de treinamento, no entanto adaptam as técnicas de aprendizado único rótulo para trabalharem diretamente com dados de problemas multirrótulo. Apesar da bibliografia nesta área ser menor que a de transformação de problemas, alguns trabalhos interessantes podem ser citados.

Em (ALVES et al., 2008) os autores abordam um paradigma de inteligência computacional chamado Sistema Imunológico Artificial (AIS) e propõem um sistema chamado MHCAIS (Multi-label Hierarchical Classification with an Artificial Immune System) que visa predizer funções de proteínas presentes na Gene Ontology. O sistema apresenta um algoritmo de classificação adaptado para classificação multirrótulo e hierárquico, o qual é expresso com um conjunto de regras IF-THEN. Essa característica facilita a compreensão por parte de usuários biólogos.

(MCCALLUM, 1999) propõe um modelo gerador de probabilidade que utiliza técnicas bayesianas para gerar diferentes conjuntos de palavras para cada rótulo. Com base nesse modelo, documentos multirrótulo são gerados pela combinação das distribuições de palavras de cada rótulo, ou seja, o algoritmo estima quais classes são responsáveis pela geração de determinadas palavras em cada documento de treinamento. Os resultados encontrados foram comparados com o algoritmo Naive Bayes Binário e obtiveram melhor desempenho para coleções menores.

\begin{tabular}{cc} 
Ex. & Rót. \\
\hline 1 & $\lambda_{1,4}$ \\
2 & $\lambda_{3,4}$ \\
3 & $\lambda_{1}$ \\
4 & $\lambda_{2,3,4}$
\end{tabular}

Tabela 6: Conjuntos de treinamento transformados em único rótulo utilizando o método LP (TSOUMAKAS et al., 2010). 
Em (TSOUMAKAS et al., 2011b) os autores utilizaram a biblioteca Weka ${ }^{1}$, a qual é amplamente referenciada e utilizada na área de Aprendizado de Máquina por apresentar importantes implementações de algoritmos de classificação único rótulo, para desenvolver uma ferramenta chamada MuLAN, a qual estende as funcionalidades da biblioteca Weka para problemas de aprendizado multirrótulo. A ferramenta MuLAN apresenta implementações de algoritmos como o ML-kNN (Multi-Label k-Nearest Neighbors) proposto por (ZHANG; ZHOU, 2007), o qual é uma adaptação do algoritmo kNN (k-Nearest Neighbors) que para cada exemplo apresentado ao classificador, os rótulos são associados aos $k$ exemplos vizinhos mais próximos (de acordo com alguma medida de distância). Em seguida é efetuada uma contagem dos vizinhos associados à cada rótulo para, então, utilizar o princípio de maximum posteriori para definir os rótulos de um novo exemplo.

\subsubsection{Avaliação de Classificadores Multirrótulo}

A avaliação de um sistema de classificação automática de textos é dada pela classificação de documentos em uma coleção de teste. Assim como a coleção de treinamento, esse corpus possui documentos previamente classificados por especialistas e é separado da coleção original antes do sistema executar o treinamento, para que o teste seja efetuado com documentos nunca antes processados pelo sistema. Ao final do processamento da coleção de teste, as classificações atribuídas pelo sistema são comparadas com as classificações originais de cada documento. Como medida de desempenho do classificador, em geral, utiliza-se a Acurácia, que corresponde ao número de exemplos de teste corretamente classificados dividido pela quantidade total de exemplos de teste. Como complementação a essa métrica, as medidas de precisão, revocação e medida-F são comumente utilizadas. A precisão é dada pela divisão do número de categorias corretamente atribuídas pelo total de classes sugeridas pelo sistema. Já a revocação é dada pela divisão do número de categorias corretamente atribuídas pelo total de categorias corretas, ou que deveriam ter sido preditas pelo classificador. Assim, a precisão reflete a exatidão do classificador, enquanto a revocação reflete a abrangência das asserções do sistema. Por último, a medida-F sintetiza as medidas de precisão e revocação em uma média harmônica.

Contudo, os métodos de avaliação de classificadores único rótulo não podem ser aplicados em problemas multirrótulo. Na avaliação de classificadores único rótulo é esperado que cada previsão aponte apenas um rótulo. Essa característica pode levar à imprecisões, uma vez que na classificação multirrótulo uma instância nova pode ser classificada de maneira

\footnotetext{
${ }^{1}$ http://www.cs.waikato.ac.nz/ml/weka
} 
parcialmente incorreta ou correta, dada a quantidade de rótulos que cada exemplo original apresenta. Isso decorre de situações em que o classificador atribui corretamente pelo menos um rótulo ao qual o exemplo pertença, deixando de atribuir outros rótulos corretos ou associando rótulos incorretos (VALLIM, 2010). A avaliação de problemas multirrótulo pode ser baseada na classificação realizada, utilizando diretamente os rótulos atribuídos pelo classificador para cada novo exemplo de teste ou utilizando um ranking de predições, no qual são observadas as posições.

Considerando o conjunto de rótulos $L=\left\{\lambda_{\mathrm{j}}: j=1 \ldots q\right\}$, a definição formal das medidas de avaliação é considerada um conjunto de exemplos multirrótulo $\left\{\left(\vec{x}_{\mathrm{i}}, Y_{i}\right): Y_{i} \subseteq L, i=\right.$ $1,2, \ldots, m\}$. O conjunto de rótulos preditos pelo classificador para um exemplo $\overrightarrow{x_{\mathrm{i}}}$ é dado por $Z_{i}$ (TSOUMAKAS et al., 2010).

Em (SCHAPIRE; SINGER, 2000), os autores utilizam a medida chamada Hamming Loss que denota a porcentagem de rótulos preditos incorretamente em relação à quantidade total de rótulos. O $\Delta$ no cálculo do Hamming Loss corresponde à operação booleana de ou exclusivo (XOR), a qual representa a diferença simétrica entre dois conjuntos de rótulos. O valor ótimo para o Hamming Loss é zero. A fórmula dessa medida é mostrada na Equação 3.1. Nas outras equações são mostradas as equações das outras medidas de avaliação para problemas multirrótulo citadas em (TSOUMAKAS et al., 2010), sendo Acurácia (3.2), precisão (3.3), revocação (3.4) e medida-F (3.5).

$$
\begin{aligned}
& \text { HammingLoss }=\frac{1}{m} \sum_{i=1}^{m} \frac{\left|Y_{i} \Delta Z_{i}\right|}{M} \\
& \text { Acurácia }=\frac{1}{m} \sum_{i=1}^{m} \frac{\left|Y_{i} \bigcap Z_{i}\right|}{\left|Y_{i} \bigcup Z_{i}\right|} \\
& \text { Precisão }=\frac{1}{m} \sum_{i=1}^{m} \frac{\left|Y_{i} \bigcap Z_{i}\right|}{\left|Z_{\mathrm{i}}\right|} \\
& \text { Revocaçãa }=\frac{1}{m} \sum_{i=1}^{m} \frac{\left|Y_{i} \bigcap Z_{i}\right|}{\left|Y_{\mathrm{i}}\right|} \\
& \text { Medida } F=2 \times \frac{\text { Precisão } \times \text { Revocação }}{\text { Precisão }+ \text { Revocação }}
\end{aligned}
$$

Segundo (TSOUMAKAS et al., 2010), outra maneira de se obter as métricas de precisão e revocação é por meio das operações de média micro-averaging e macro-averaging. Essas 
medidas tomam como base as métricas binárias de verdadeiros positivos $\left(t p_{Y_{i}}\right)$, falsos positivos $\left(f p_{Y_{i}}\right)$, verdadeiros negativos $\left(t n_{Y_{i}}\right)$ e falsos negativos $\left(f n_{Y_{i}}\right)$.

As medidas de micro-averaging, representadas pelas Equações 3.6 e 3.7 são calculadas com base nas medidas de precisão e revocação de cada asserção do classificador, ou seja, elas atribuem igual importância aos resultados obtidos por documento. As medidas de macro-averaging, mostradas nas Equações 3.8 e 3.9 são computadas pela média das medidas de precisão e revocação obtidas por classe, ou seja, atribuem igual importância aos resultados obtidos por classe (MANNING et al., 2008). Segundo (JACKSON; MOULINIER, 2002), medidas micro-averaging privilegiam classes com um número maior de exemplos de teste. Por essa razão, essas medidas são utilizadas em sistemas cuja alta densidade de determinadas classes é importante para o usuário. Já as métricas macro-averaging tratam as classes igualitariamente e por esse motivo são utilizadas para avaliar como um todo sistemas com classes balanceadas, sem favorecer classes com maior densidade de exemplos.

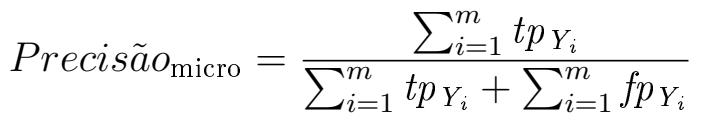

$$
\begin{aligned}
& \text { Revocaçã } O_{\text {micro }}=\frac{\sum_{i=1}^{m} t p_{Y_{i}}}{\sum_{i=1}^{m} t p_{Y_{i}}+\sum_{i=1}^{m} f n_{Y_{i}}} \\
& \operatorname{Precisa\tilde {a}} O_{\text {macro }}=\frac{\sum_{i=1}^{c} \operatorname{Precis}_{\tilde{a}} o_{\mathrm{i}}}{c}
\end{aligned}
$$

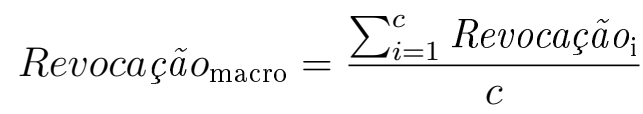

\subsection{Classificação Automática de Patentes}

(LUPU et al., 2011) definem a classificação automática de patentes como um processo computacional que analisa documentos de patentes em formato eletrônico e, de acordo com seus conteúdos, sugere ou atribui a cada documento uma ou mais classes pertencentes a uma taxonomia específica. Os autores ainda acrescentam que, para uma maior eficácia do processo, é necessária uma coleção com tamanho suficiente, previamente classificada por especialistas e com classes bem distribuídas para se treinar e testar o sistema (LUPU et al., 2011). Segundo os mesmos pesquisadores, a classificação automática de patentes tem aplicações diversas, como manter as classificações organizadas e consistentes e facilitar 
pesquisas pelo estado da arte de tecnologias, patenteabilidade e validade de invenções e liberdade de operação em determinados mercados (LUPU et al., 2011). Comumente, profissionais utilizam as classificações para delimitar conjuntos de documentos nos quais desejam fazer buscas, melhorando a eficiência das pesquisas.

A eficiência de sistemas de classificação automática de textos que utilizam a abordagem de Aprendizado de Máquina é altamente dependente da qualidade dos dados utilizados para treinar o sistema. Assim, a estruturação de um documento de patente com campos bem definidos ganha importância na escolha das informações mais representativas. De maneira geral, um documento de patente é divido em três partes: (i) dados bibliográficos, (ii) reivindicações e (iii) texto completo. No grupo (i) estão o número da patente, os requisitantes, os inventores, o título e o resumo. No grupo (ii), estão as reivindicações e no grupo (iii) está a descrição completa da patente, a qual, além de conter descrição textual, pode trazer figuras e gráficos explicativos. Patentes são documentos semi-estruturados, pois possuem campos estruturados, como número da patente, data, inventor e concessionário e campos não-estruturados, como o resumo e a descrição. Essa característica semi-estruturada pode ser considerada no momento do processamento da coleção.

Estudos tem comprovado que para uma melhor precisão do sistema, somente algumas informações devem ser utilizadas (LUPU et al., 2011). Campos como os nomes dos inventores e requisitantes apresentam um grande poder de classificação, dado que inventores e requisitantes trabalham com áreas específicas. Em contrapartida, as reivindicações apresentam baixa representatividade, pois contêm textos mais vagos e com muitas palavras ambíguas. Pesquisas tem apontado que, para classificadores automáticos, o resumo dos documentos possui mais representatividade do que as reivindicações. Campos descritivos com muitas figuras, como é o caso de patentes das áreas de Mecânica e Química, perdem desempenho quando processados por classificadores textuais. Assim, necessitam de tratamento específico para extrair informação destes campos. A grande quantidade de palavras também é encarada como problema. Estudos tem demonstrado que documentos menores em grande quantidade são mais eficientes que grandes documentos em pouca quantidade (LUPU et al., 2011). Assim, os campos bibliográficos (título, resumo, nomes dos inventores e requisitantes) tem sido os mais utilizados na classificação automática de patentes e, em alguns trabalhos, tem se utilizado a descrição da patente, mas com a quantidade máxima de palavras limitada entre 350 e 400 palavras (LUPU et al., 2011).

Diferentemente de outros tipos de dados, coleções de documentos textuais, em geral, 
não são classificadas de acordo com atributos intrínsecos e objetivos, como a quantidade de palavras ou frases. Documentos textuais, em geral, são categorizados por critérios externos e subjetivos. Os documentos são agrupados de acordo com a análise e conhecimento prévio de um especialista de domínio. De acordo com (LUPU et al., 2011), coleções com esse comportamento tendem a demonstrar uma distribuição dos documentos pelas categorias de acordo com o Princípio de Pareto, segundo o qual $80 \%$ dos documentos são classificados em $20 \%$ das classes.

Um comportamento de acordo com o Princípio de Pareto representa um desafio para a classificação automática de documentos, já que a maioria das técnicas empregadas são baseadas em exemplos e necessitam treinar com a maior quantidade possível de documentos representativos de cada classe. Em uma coleção que reflete o Princípio de Pareto, apesar de $20 \%$ das classes estarem bem representadas, ainda existirão $80 \%$ das categorias sendo compartilhadas por apenas $20 \%$ dos documentos, ou seja, tais classes terão poucos documentos representativos em relação às demais e poderão não ser identificadas pelo classificador.

Como citado anteriormente, sistemas de classificação automática de textos são treinados com coleções de documentos previamente classificadas por especialistas. Essa característica implica que sistemas treinados em documentos em um determinado idioma, somente poderão classificar documentos nesse idioma. (LUPU et al., 2011) citam a dificuldade atual de se encontrar coleções completas de patentes em outros idiomas diferentes do inglês e estabelece algumas razões para esse contexto (LUPU et al., 2011): (1) poucas patentes são registradas concomitantemente no idioma nativo dos inventores e em outro idioma de alcance internacional, como o inglês; (2) determinados países possuem poucos inventores e em campos específicos, o que diminui a diversidade das classes de patente; (3) muitos documentos de patente em formato de imagem escaneada, demandam um bom processamento de OCR (Optical Character Recognition) para traduzir as imagens em documentos textuais; (4) grandes coleções mantidas por organizações privadas e que são disponibilizadas apenas mediante pagamento, dificultando o acesso a muitos documentos importantes; (5) patentes classificadas de acordo com taxonomias específicas, principalmente de escritórios menos representativos internacionalmente, o que demanda uma nova análise desses documentos para readequá-los ao IPC. 


\subsection{Mineração de Texto Aplicada à Bioinformática}

Motivados pelo grande potencial de descoberta de novos conhecimentos e desafiados pela complexidade de análise de textos em linguagem natural, pesquisadores de diversas áreas tem aumentado seu interesse em técnicas de mineração de texto aplicadas a domínios específicos. Segundo (BAXEVANIS; OUELLETTE, 2004), a aplicação de técnicas de Text Mining para processar textos das áreas de Biologia, Química e Medicina deu origem à área de pesquisa conhecida como Biomedical Text Mining, também chamada de BioNLP (Biomedical Natural Language Processing).

A extração de conhecimento de textos não estruturados é uma tarefa complexa. De acordo com (RODRIGUEZ-ESTEBAN, 2009), registros clínicos, artigos científicos e anotações das áreas médica e biológica podem trazer palavras em idiomas diferentes, jargões e nomenclaturas criados no ambiente de trabalho, dificultando a análise automática do conhecimento. Nesses casos, o uso de artefatos linguísticos como ontologias e dicionários, aliados ao conhecimento especializado de domínio são importantes para processar essas coleções. Neste trabalho, (RODRIGUEZ-ESTEBAN, 2009) cita terminologias controladas importantes para a área de Bioinformática como a nomenclatura de genes $\mathrm{HUGO}^{2}$ e a Gene Ontology ${ }^{3}$. Essas ferramentas são atualizadas por especialistas de domínio e permitem relacionar diferentes termos e informações da área de Bioinformática.

Em (KIM et al., 2003), os autores propõem uma coleção de documentos de Bioinformática com anotações semânticas chamada GENIA corpus. Essa coleção faz parte do projeto GENIA ${ }^{4}$ e conta com resumos coletados na MEDLINE 5 e anotados por especialistas de domínio. Para o projeto GENIA também foi desenvolvida uma taxonomia chamada GENIA Ontology, a qual é utilizada para anotar semanticamente cada documento. O projeto também utiliza anotações sintáticas para identificar entidades como nomes de pessoas, organizações e termos biológicos. Com o trabalho, os autores visam disponibilizar à comunidade científica de Bioinformática uma coleção amplamente anotada que auxilie nas pesquisas em BioNLP.

Outra área cuja aplicação da mineração de textos merece destaque é a Bioinformática Translacional. De acordo com (BUTTE, 2008), esse domínio foi definido pela AMIA (Associação Americana de Informática em Saúde, do inglês American Medical Informatics Association) como uma sub-área da Informática na qual busca-se extrair conhecimento

\footnotetext{
${ }^{2}$ http://www.genenames.org

${ }^{3}$ http://www.geneontology.org/

${ }^{4}$ http://www.nactem.ac.uk/genia

${ }^{5}$ http://www.ncbi.nlm.nih.gov/pubmed
} 
dos resultados de pesquisa e transformá-lo em benefícios à saúde pública. Em (COHEN; HUNTER, 2013) é analisada a aplicação de técnicas de mineração de texto na Bioinformática Translacional. O estudo ressalta que os maiores desafios estão no processamento de textos em linguagem natural, especialmente artigos científicos e registros clínicos. Os autores destacam como sub-tarefas importantes o reconhecimento de nomes de genes e fenótipos e o mapeamento de seus conceitos em ontologias da área. 


\section{Recuperação de Informação}

Esse capítulo apresenta os conceitos de Recuperação de Informação implementados no módulo de IR do sistema BPS. O capítulo descreve formalmente o processo de IR, avaliação de Recuperação de Informação e artefatos linguísticos desenvolvidos para a área de Bioinformática.

\subsection{Recuperação de Informação Textual}

Segundo (BAEZA-YATES; RIBEIRO-NETO, 1999), a Recuperação de Informação, do inglês Information Retrieval (IR), é o campo do conhecimento responsável por estudar representações, organizações e meios de armazenamento e acesso de itens de informação. As tecnologias propostas por especialistas da área visam permitir ao usuário encontrar, de maneira mais fácil, a informação de interesse. O desafio de IR vai além de desenvolver sistemas que apenas retornem textos com palavras iguais às presentes na consulta, procura-se encontrar documentos que abordem assuntos semanticamente relacionados. As pesquisas em IR abrangem modelagem, indexação e classificação de textos, além de interfaces de usuário e visualização de dados. Apesar do crescimento da área desde a década de 1980, a IR ganhou notoriedade apenas em meados de 1990 com a popularização da World Wide Web. A grande quantidade de hipertextos disponíveis na Internet fez com que a demanda por buscas eficientes aumentasse expressivamente.

Como forma de extrair a essência de um texto, conjuntos de palavras-chave ou termos de índice (index terms) são frequentemente utilizados para representar um documento. Esses termos podem ser extraídos do próprio texto ou atribuídos por um especialista para caracterizarem a visão lógica do documento (BAEZA-YATES; RIBEIRO-NETO, 1999). Essa representação pode ser feita utilizando todas as palavras do documento (full text logical view). Entretanto, transformações são aplicadas no texto para melhorar a eficiência do processamento de coleções grandes. Essa tarefa reduz o conjunto de termos eliminando palavras que não são representativas para o documento como artigos e conectores (stop- 


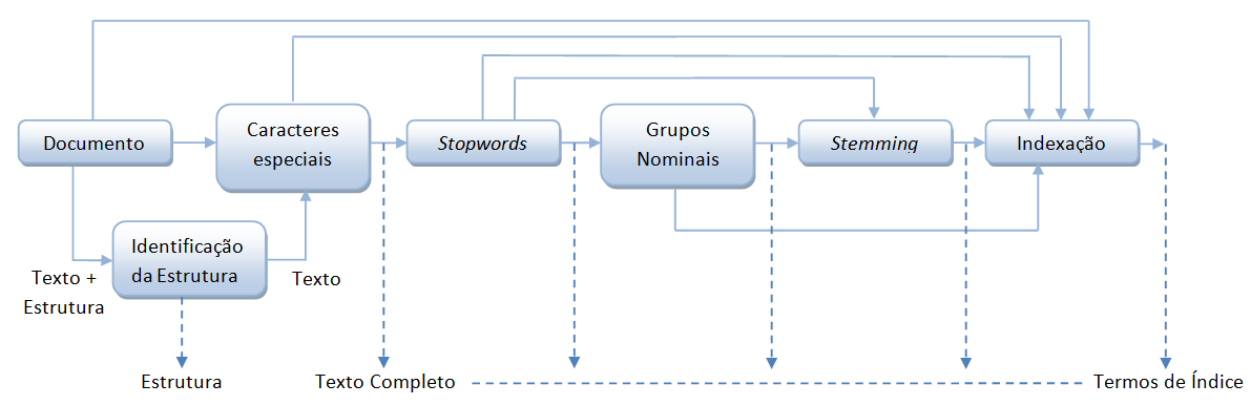

Figura 4: Visão lógica do documento (BAEZA-YATES; RIBEIRO-NETO, 1999).

words), reduzindo cada palavra ao seu radical (stemming) e eliminando grupos nominais como advérbios, adjetivos e verbos. O diagrama da Figura 4 ilustra a visão lógica de um documento desde a representação completa até o conjunto reduzido de termos representativos.

De acordo com (BAEZA-YATES; RIBEIRO-NETO, 1999), nem todos os termos de índice de um documento são suficientemente representativos para descrevê-lo, assim são utilizados modelos que visam quantificar a representatividade de cada termo para o documento e para a coleção como um todo. Os autores citam três modelos clássicos: (1) Modelo Booleano, (2) Modelo Probabilístico e (3) Modelo de Espaço Vetorial ou Modelo Vetorial.

O modelo (1) utiliza uma representação binária para o peso dos termos de índice, os quais são marcados com 1 ou 0, ou seja, se o termo está presente ou não no documento. Esse modelo é considerado limitado por não permitir uma escala de relevância gradativa para os termos. O modelo (2) também utiliza pesos binários, contudo utiliza o princípio da probabilidade para calcular a chance de encontrar determinado documento, dada uma consulta. Este modelo apresenta a mesma desvantagem do modelo booleano, além de necessitar da definição prévia dos conjuntos de documentos relevantes e não relevantes presentes na coleção. Por fim, o modelo (3) visa eliminar as desvantagens dos outros modelos ao propor uma representação não binária para os pesos dos termos de índice e um grau de similaridade para o relacionamento entre os documentos (BAEZA-YATES; RIBEIRO-NETO, 1999). Do ponto de vista do usuário, resultados exibidos em um ranking ordenado pelo grau de similaridade oferecem mais precisão na avaliação dos resultados (BAEZA-YATES; RIBEIRO-NETO, 1999).

Segundo (BAEZA-YATES; RIBEIRO-NETO, 1999), formalmente o modelo vetorial segue a seguinte definição: seja uma coleção de documentos textuais $D=\left\{d_{1}, d_{2}, \ldots, d_{\mathrm{j}}\right\}$ e $K=$ $\left\{k_{1}, k_{2}, \ldots, k_{\mathrm{t}}\right\}$ o conjunto de termos de índice encontrados na coleção $D$. Para cada termo de índice $k_{i}$ de um documento $d_{j}$ é associado um peso $w_{i, j}$ que quantifica a importância 
semântica do termo de índice para o documento. Dessa maneira, cada documento $d_{j} \in D$ passa a ser representado por um vetor de pesos $\vec{d}_{\mathrm{j}}=\left(w_{1, \mathrm{j}}, w_{2, \mathrm{j}}, \ldots, w_{\mathrm{t}, \mathrm{j}}\right)$.

Existem diferentes técnicas de atribuição de pesos. A técnica mais simples utiliza a frequência do termo de índice $k_{i}$ dentro do documento $d_{j}$. Nesse caso, se o termo de índice $k_{i}$ não estiver presente no documento $d_{j}$ o peso $w_{i, j}=0$. Como alternativa à essa técnica, é comum a aplicação de estratégias de ponderação para o cálculo dos pesos de cada termo. Essas estratégias consideram a representatividade do termo de índice no documento e na coleção. Um dos esquemas mais difundidos é o tf-idf (SALTON et al., 1975), o qual é uma combinação dos fatores $t f$, do inglês term frequency e $i d f$, do inglês inverse document frequency. O fator $t f$, mostrado na Equação 4.1, denota a similaridade intra-documento e é dado pela frequência de um termo em um documento dividida pela máxima frequência encontrada dentro do mesmo documento. O fator $i d f$, mostrado pela Equação 4.2, denota a dissimilaridade inter-documentos e é dado pelo inverso da frequência de um termo entre os documentos da coleção (BAEZA-YATES; RIBEIRO-NETO, 1999). Assim, o cálculo do peso é dado pelo produto dos fatores $t f$ e $i d f$. A Equação 4.3 mostra o cálculo.

$$
\begin{gathered}
t f_{\mathrm{i}, \mathrm{j}}=\frac{\text { frequência do termo } i \text { no documento } j}{\text { frequência máxima dentro do documento } j}=\frac{f r e q_{\mathrm{i}, \mathrm{j}}}{\max \left(\text { freq }_{1, \mathrm{j}}\right)} \\
i d f_{\mathrm{i}}=\log \frac{\text { total de documentos da coleção }}{\text { total de documentos com o termo } i}+1=\log \frac{N}{n_{\mathrm{i}}}+1 \\
w_{\mathrm{i}, \mathrm{j}}=t f_{\mathrm{i}, \mathrm{j}} \times i d f_{\mathrm{i}}
\end{gathered}
$$

A definição apresentada no parágrafo anterior trata da coleção como um todo, onde os pesos e as similaridades são calculados apenas entre os documentos de uma mesma coleção. Em caso de novas consultas, ou seja, comparação de novos documentos ou expressões com os documentos da coleção original, os pesos dos termos de índice da consulta devem ser calculados. (BAEZA-YATES; RIBEIRO-NETO, 1999) sugerem o cálculo apresentado na Equação 4.4 .

$$
w_{\mathrm{i}, \mathrm{q}}=\left(0,5+0,5 t f_{\mathrm{i}, \mathrm{q}}\right) \times i d f_{\mathrm{i}}
$$

Os relacionamentos são dados por grau de similaridade, ou seja, dependendo dos termos presentes em uma consulta, esta pode estar mais ou menos relacionada à determinados documentos. Essa métrica varia de 0 a 1 , sendo 1 o valor para documentos 
iguais. O grau de similaridade é obtido por alguma medida de correlação entre vetores, por exemplo, o cosseno do ângulo entre eles. Esse cálculo é apresentado na Equação 4.5 (BAEZA-YATES; RIBEIRO-NETO, 1999).

$$
\operatorname{sim}\left(d_{\mathrm{j}}, q\right)=\frac{\vec{d}_{\mathrm{j}} \cdot \vec{q}}{\left|\vec{d}_{\mathrm{j}}\right| \times|\vec{q}|}=\frac{\sum_{i=1}^{t} w_{\mathrm{i}, \mathrm{j}} \times w_{\mathrm{i}, \mathrm{q}}}{\sqrt{\sum_{i=1}^{t} w_{\mathrm{i}, \mathrm{j}}^{2}} \times \sqrt{\sum_{j=1}^{t} w_{\mathrm{i}, \mathrm{q}}^{2}}}
$$

\subsection{Avaliação de Recuperação de Informação Textual}

De acordo com (BAEZA-YATES; RIBEIRO-NETO, 1999), a avaliação de sistemas de Recuperação de Informação deve considerar a tarefa de recuperação implementada pelo sistema. Essa tarefa pode ser a recuperação em lote (batch), ou seja, o usuário efetua uma consulta e o sistema retorna resultados, ou essa tarefa pode ser dada por uma sessão interativa, ou seja, o usuário segue passos definidos e especifica as informações de seu interesse interativamente.

A abordagem interativa requer interfaces mais elaboradas, respostas mais rápidas do sistema e empenho do usuário que utiliza o sistema ao mesmo tempo que fornece informações de avaliação. Já a abordagem de recuperação por lote é mais simples e amplamente utilizada em experimentos de laboratório, pois permite mais repetições e apresenta maior escalabilidade (BAEZA-YATES; RIBEIRO-NETO, 1999).

Medidas comumente utilizadas para avaliar sistemas de IR em lote são a Precisão, Revocação e Medida-F. Essas métricas são obtidas da comparação dos relacionamentos apontados pelo sistema como relevantes com os relacionamentos relevantes de uma coleção

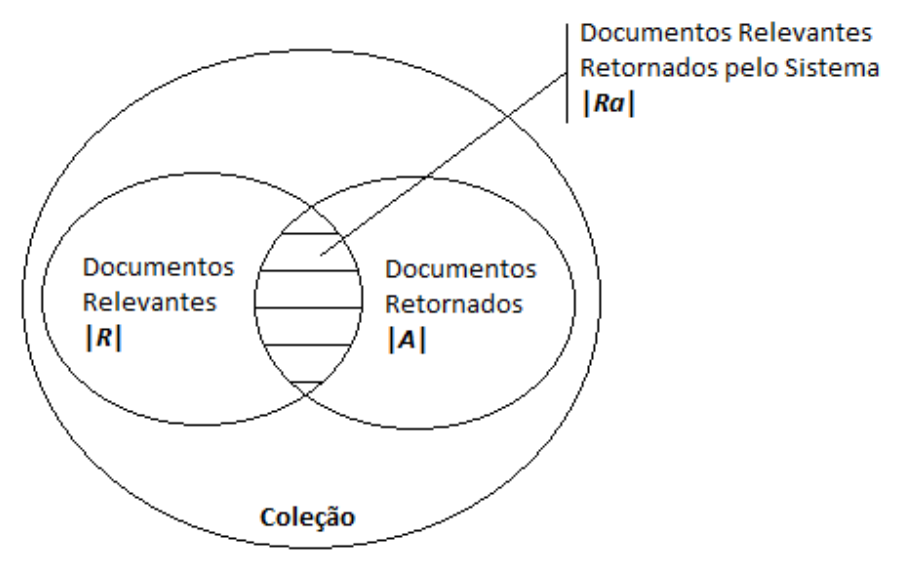

Figura 5: Representação dos conjuntos de documentos que são base para os cálculos de Precisão e revocação (BAEZA-YATES; RIBEIRO-NETO, 1999). 
de referência. Em geral, as coleções de referência são conjuntos de documentos de um determinado domínio previamente analisados por especialistas, que marcam os documentos ou relacionamentos como mais ou menos relevantes(BAEZA-YATES; RIBEIRO-NETO, 1999).

A precisão denota a exatidão do sistema, ou seja, é a fração de documentos retornados pelo sistema e que são considerados relevantes (BAEZA-YATES; RIBEIRO-NETO, 1999). A revocação demonstra a abrangência das consultas efetuadas pelo sistema, ou seja, é a fração de documentos relevantes recuperados pelo sistema que estão entre os documentos relevantes da coleção (BAEZA-YATES; RIBEIRO-NETO, 1999). Por fim, a medida-F sintetiza as medidas de Precisão e revocação em uma média harmônica.

A Figura 5 ilustra o contexto das métricas de Precisão e Revocação. Segundo definição formal de (BAEZA-YATES; RIBEIRO-NETO, 1999), seja $I$ uma informação requisitada pelo usuário e $R$ o subconjunto de documentos relevantes de tamanho $|R|$. O sistema de Recuperação de Informação processa a requisição $I$ do usuário e aponta que um subconjunto $A$ de documentos estão relacionados à $I$. A intersecção dos documentos relevantes $R$ com os documentos ditos pelo sistema como relevantes $A$ é representada por $R a$. As Equações 4.6, 4.7 e 4.8 apresentam as métricas de avaliação com base nessa definição formal.

$$
\begin{gathered}
\text { Precisão }=\frac{|R a|}{|A|} \\
\text { Revocação }=\frac{|R a|}{|R|} \\
\text { Medida_F }=2 \times \frac{\text { Precisão } \times \text { Revocaçãa }}{\text { Precisão }+ \text { Revocação }}
\end{gathered}
$$

\subsection{Artefatos Linguísticos para IR em Bioinformática}

Devido à complexidade do processamento de textos livres, sistemas de IR frequentemente focam em aspectos linguísticos para executar suas tarefas. As abordagens podem compreender o processamento das palavras individualmente, agrupamento de palavras $(n$ gram e frases inteiras) e a identificação e o processamento de conceitos e relações semânticas. Para auxiliar essas tarefas é comum a utilização de artefatos linguísticos como glossários, ontologias, tesauros e taxonomias. (LUPU et al., 2011) definem esses artefatos como bases de conhecimento que apresentam conceitos e relacionamentos em áreas específicas e que são aceitos pelos especialistas da área. Essas bases de conhecimento são usadas 
para relacionar textos em diferentes idiomas, classificar documentos, expandir consultas e correlacionar termos e conceitos.

Com o aumento constante de publicações digitais, pesquisadores da área de Bioinformática têm se empenhado em desenvolver artefatos que auxiliem na padronização das informações, processamento e extração de conhecimento de publicações científicas, registros clínicos e patentes. Um desses artefatos é a nomenclatura de genes humanos $\mathrm{HUGO}^{1}$, a qual é mantida pelo HGNC (Hugo Gene Nomenclature Commitee) no Instituto Europeu de Bioinformática (EBI). O comitê conta com especialistas que analisam e definem nomes, símbolos e descrições únicas e não ambíguas para os genes humanos. O objetivo dessa padronização é facilitar a recuperação de informação relacionada a genes humanos em publicações científicas (GRAY et al., 2013). O HGNC disponibiliza em seu portal na Internet três tipos de consulta ${ }^{2}$ sendo buscas (i) rápidas e (ii) avançadas por termos específicos e (iii) consultas por lista de nomenclaturas. Além dessas ferramentas, o comitê também disponibiliza um Web Service ${ }^{3}$ para consultas automáticas.

A cada ano, diversas iniciativas surgem com a proposta de criar ontologias para domínios específicos e auxiliar na estruturação do conhecimento nessas áreas. Entretanto, para um melhor aproveitamento dessas informações se faz necessária maior integração entre essas ontologias. Segundo (SMITH et al., 2007), um dos problemas da proliferação de ontologias é a dificuldade de integração entre elas. Visando minimizar essas dificuldades, foi criada a iniciativa The Open Biological and Biomedical Ontologies ${ }^{4}$ (OBO), mantida atualmente pela OBO Foundry. Frequentemente constata-se que o avanço de pesquisas em determinada área colabora com trabalhos de outras áreas, exemplos são identificados na genética, química e biologia, com pesquisas aplicadas a indivíduos de uma mesma espécie ou entre espécies diferentes (SMITH et al., 2007). A composição da OBO é o resultado de um trabalho colaborativo entre diversos especialistas que analisam as ontologias candidatas de acordo com os princípios e o modelo de boas práticas definido pela entidade. Em sua primeira fase de revisão, foram integradas as ontologias Chemical Entities of Biological Interest ${ }^{5}$ (CHEBI), Gene Ontology ${ }^{6}$ (GO), Phenotypic Quality Ontology ${ }^{7}$ (PATO), Protein Ontology ${ }^{8}$ (PRO), Xenopus Anatomy Ontology ${ }^{9}$ (XAO), Zebrafish Anatomy On-

\footnotetext{
${ }^{1}$ http://www.genenames.org

${ }^{2}$ http://www.genenames.org/searchgenes/search-genes-documentation

${ }^{3}$ http://www.avatar.se/HGNC

${ }^{4}$ http://www.obofoundry.org

${ }^{5}$ http://www.ebi.ac.uk/chebi

${ }^{6}$ http://www.geneontology.org

${ }^{7}$ http://obofoundry.org/wiki/index.php/PATO:Main_Page

${ }^{8}$ http://pir.georgetown.edu/pro

${ }^{9}$ http://www.xenbase.org/anatomy/xao.do? method=display
} 


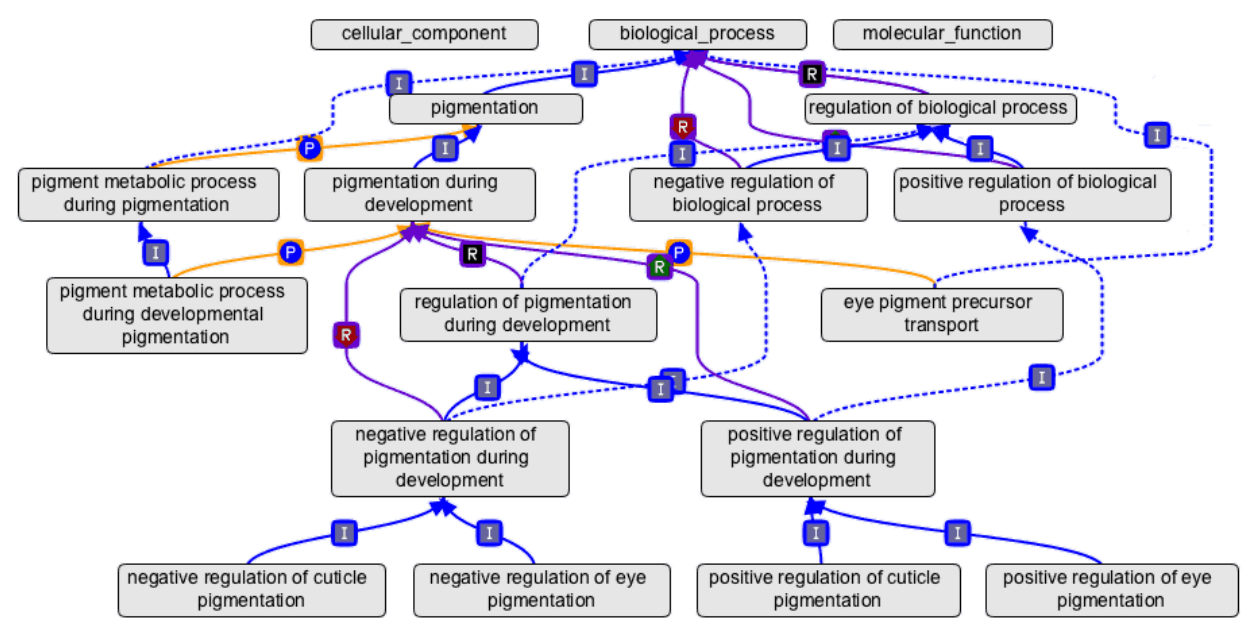

Figura 6: Exemplo de estrutura da Gene Ontology com um pequeno conjunto de termos pertencentes à ontologia de Processos Biológicos. (THE GENE ONTOLOGY CONSORTIUM, 2013c).

tology ${ }^{10}(\mathrm{ZFA})$.

Entre as ontologias que compõem a OBO, a GO destaca-se como o maior projeto de padronização de termos e genes da área de Bioinformática. O vocabulário controlado da Gene Ontology é apresentado em uma base de dados com termos, descrições e relacionamentos entre genes e produtos gênicos de diferentes espécies (ASHBURNER et al., 2000). Segundo (THE GENE ONTOLOGY CONSORTIUM, 2013a), a GO é composta por três ontologias independentes, sendo (i) Processos Biológicos, que se refere às "operações ou conjuntos de eventos moleculares com início e fim, relativos ao funcionamento integrado de unidades como células, tecidos, órgãos e organismos", (ii) Funções Moleculares que é definida pelas "atividades elementares de produtos gênicos em nível molecular, como ligação e catálise" e (iii) Componentes Celulares que agrupa informações sobre "partes das células e seu ambiente extracelular".

A estrutura da Gene Ontology é representada por um grafo acíclico, ou seja, as relações entre os termos não forma ciclos. A Figura 6 ilustra a estrutura da GO. Cada termo é um nó e as arestas são as ligações diretas entre os termos. Os termos mais próximos das raízes (Componente Celular, Processos Biológicos e Funções Moleculares) são mais genéricos, ao passo que os mais distantes são específicos. Apesar dessa característica hierárquica, os termos da GO podem ter mais de um pai, ou seja, apresentar relacionamento com mais de um termo (THE GENE ONTOLOGY CONSORTIUM, 2013c). A ontologia convenciona três tipos de relação entre os termos, sendo (i) "é um", o qual denota que um termo A é um subtipo de B, (ii) "parte de", que define que um termo A é parte de um todo B e (iii)

\footnotetext{
${ }^{10} \mathrm{http} / / /$ zfin.org/zf_info/anatomy/dict/sum.html
} 
"regula", onde um termo A afeta outro termo B (THE GENE ONTOLOGY CONSORTIUM, $2013 b)$.

Para o presente trabalho, optou-se pela utilização da Gene Ontology como artefato linguístico que auxiliará no processamento textual das patentes, pois é a ferramenta mais bem difundida na área da Bioinformática. A GO disponibiliza ferramentas de acesso e processamento que facilitam sua integração com outros sistemas. A integração da GO com as outras ontologias da OBO é outro atrativo para sua escolha, pois permite a utilização de outras ontologias em experimentos futuros. O Capítulo 5 descreve como a Gene Ontology foi utilizada na implementação do sistema apresentado. 


\section{Sistema de Busca Guiada de Patentes de Bioinformática $(B P S)$}

Buscando apoiar buscas por patentes, criou-se um sistema de busca guiada de patentes de Bioinformática, que utiliza informações de classificação de patentes e artefatos linguísticos da área. O sistema é referenciado pela sigla BPS, que remete à descrição em inglês de Bioinformatics Patent Search. Este capítulo apresenta detalhes da modelagem do projeto como a arquitetura, a coleção de patentes de Bioinformática utilizada e o processo de utilização das informações de classificação.

\subsection{Análise, Projeto e Arquitetura do Sistema}

Na primeira etapa do projeto foram identificados os casos de uso, atores e requisitos do sistema de busca guiada de patentes de Bioinformática (BPS). A Figura 7 apresenta o diagrama UML que ilustra os casos de uso primários e essenciais e as interações com os atores.

O sistema BPS apresenta dois casos de uso primários. O caso de uso C1 representa o processo de coletar e reindexar periodicamente a coleção de patentes de Bioinformática utilizada na classificação e busca por documentos similares. Esse caso de uso é oculto aos usuários AC2. O segundo caso C2 representa a tarefa de consultar patentes de Bioinformática por termos ou documentos completos (patentes, artigos científicos, etc). Este caso é composto por outros dois casos de uso específicos, dos quais C2.1 representa as consultas efetuadas sem a utilização das informações de classificação e C2.2 denota as consultas em que os atores correspondentes utilizam um classificador como um filtro de busca.

O primeiro grupo de atores identificado atua no caso de uso C1. Estes atores são 


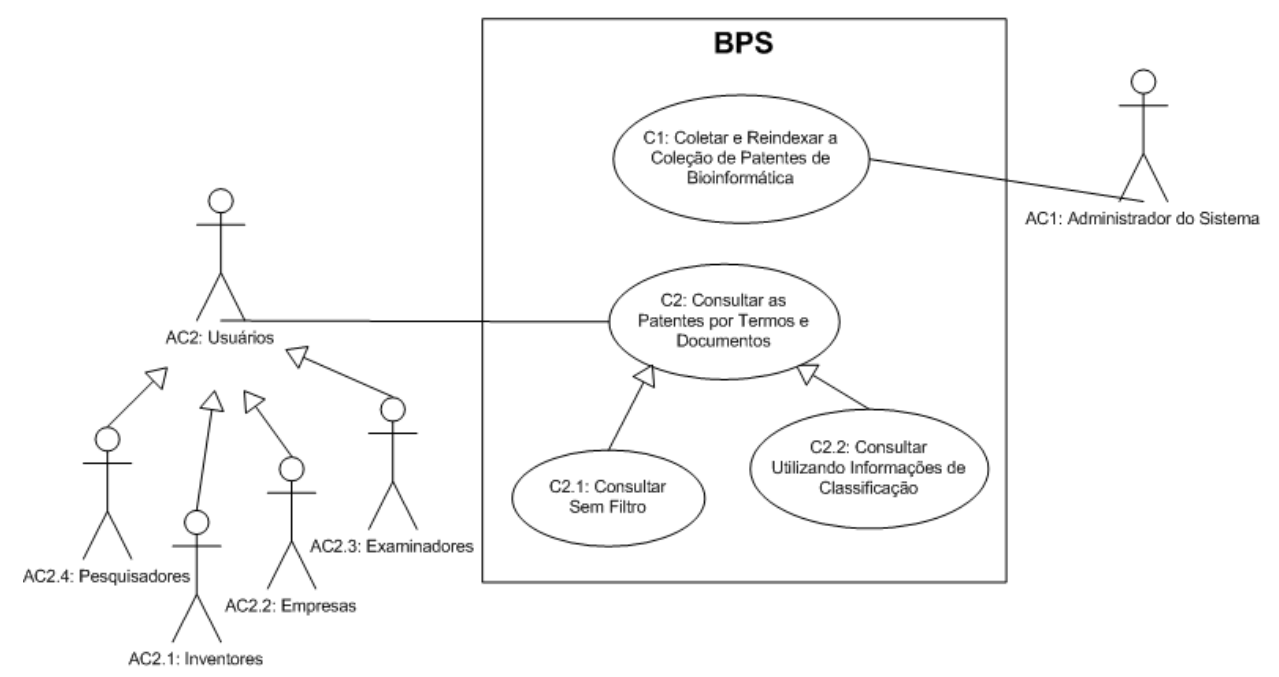

Figura 7: Casos de uso e atores do sistema de busca guiada de patentes de Bioinformática (BPS).

os administradores do sistema (AC1), os quais podem acionar a coleta e a reindexação da coleção manualmente ou agendar essa tarefa para ser executada automaticamente. O segundo grupo de atores atua nos casos de uso C2 e é caracterizado pelos usuários do sistema (AC2). Fazem parte deste grupo Inventores (AC2.1), Empresas (AC2.2), Examinadores (AC2.3) e Pesquisadores (AC2.4). No caso específico de Inventores (AC2.1) e Empresas (AC2.2) a busca utilizando o sistema é efetuada antes da formalização do pedido de patente junto aos escritórios de análise. Enquanto os Examinadores (AC2.3) utilizam o sistema durante a análise do pedido dentro do processo de pesquisa de anterioridade. Pesquisadores (AC2.4) em geral podem utilizar o sistema para buscas por patentes e tecnologias vigentes similares, objetivando o desenvolvimento de novas tecnologias ou para buscar patentes em domínio público para fabricação e comercialização de tais produtos.

Os requisitos do sistema são relatados de acordo com os casos de uso apresentados anteriormente. Assim, para o caso de uso C1 foram identificados os seguintes requisitos ocultos:

R1.1: Coletar título, resumo, descrição, número da patente, requisitantes, inventores, data de concessão, classe principal e classes secundárias das patentes de Bioinformática;

R1.2: Armazenar no banco de dados as palavras coletadas e processadas no título, resumo e descrição com as frequências correspondentes;

R1.3: Processar os textos armazenados em banco de dados, removendo caracteres especiais e stopwords (artigos, conectores, etc) e reduzindo cada palavra ao seu radical 


\section{(stemming);}

R1.4: Identificar os termos da Gene Ontology presentes no título, resumo e descrição de cada patente e armazená-los em banco de dados;

R1.5: Calcular os pesos para cada termo (original e GO) de acordo com as técnicas de contagem de frequência e $t f-i d f$ e armazená-los em banco de dados;

Para o caso de uso C2.1 foram identificados os seguintes requisitos:

R2.1: Receber como entrada palavras-chave, expressões, frases ou documentos textuais completos;

R2.2: Processar o texto de consulta, removendo caracteres especiais e stopwords (artigos, conectores, etc) e reduzindo cada palavra ao seu radical (stemming);

R2.3: Expandir a consulta identificando os termos da Gene Ontology correspondentes aos termos da consulta;

R2.4: Calcular os pesos para cada termo da consulta de acordo com a técnica escolhida (Vide Seção 6.2);

R2.5: Calcular a similaridade (distância) entre a consulta e as patentes da coleção;

R2.6: Exibir as patentes similares por ordem decrescente de grau de similaridade (distância).

O caso de uso C2.2 se assemelha ao caso anterior, diferenciando-se pelo filtro aplicado

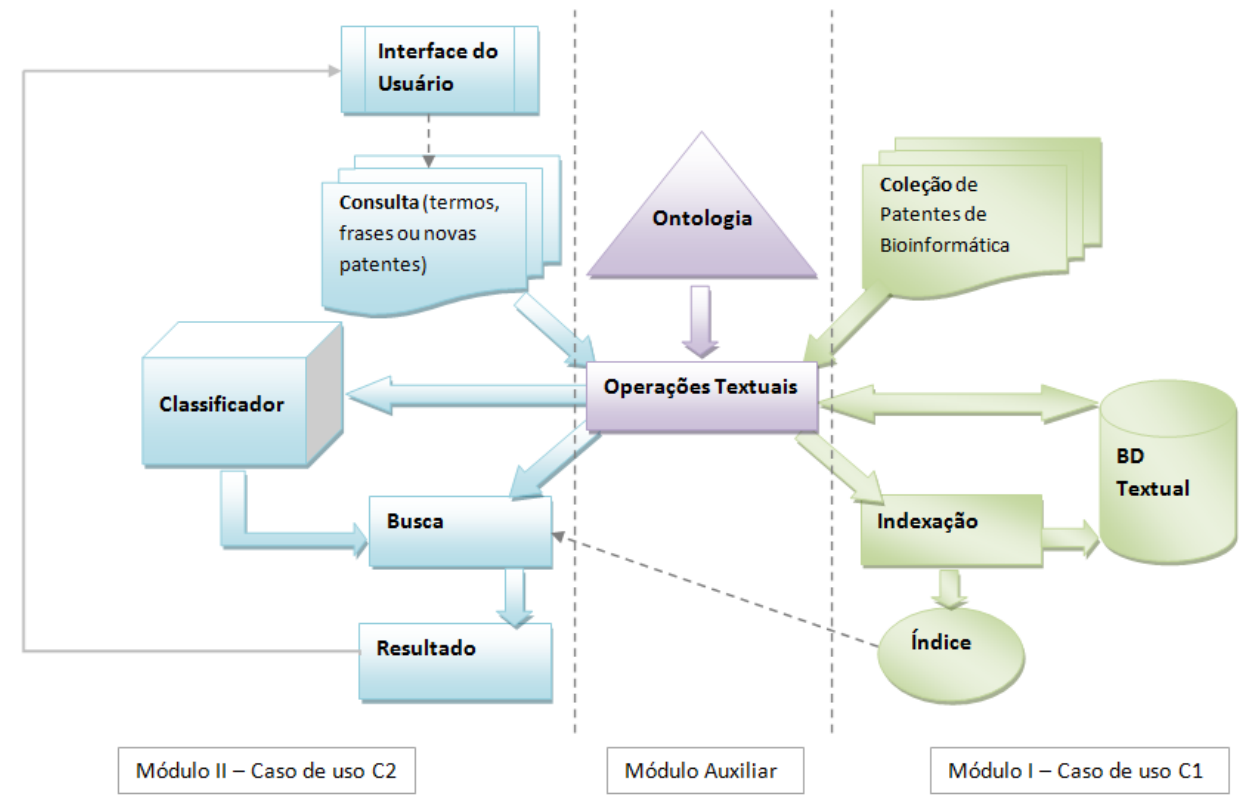

Figura 8: Arquitetura do sistema de busca guiada de patentes de Bioinformática. 
à consulta, o qual sugere classificações à consulta. Assim, os requisitos identificados para este caso foram os seguintes:

R3.1: Processar o texto de consulta, removendo caracteres especiais e stopwords (artigos, conectores, etc) e reduzindo cada palavra ao seu radical (stemming);

R3.2: Expandir a consulta identificando os termos da Gene Ontology correspondentes aos termos da consulta;

R3.3: Calcular os pesos para cada termo da consulta de acordo com a técnica escolhida;

R3.4: Classificar a consulta e gerar um ranking ordenado de maneira decrescente pelo grau de similaridade entre a consulta e as classes de Bioinformática;

R3.5: Calcular a similaridade (distância) entre a consulta e as patentes das duas classes de Bioinformática melhor classificadas em R3.4;

R3.6: Exibir o ranking de classificação e as patentes similares por ordem decrescente de grau de similaridade (distância).

Na etapa seguinte do projeto, a arquitetura do sistema foi definida a partir dos casos de uso dos requisitos identificados a etapa anterior. Conforme ilustrado na Figura 8, o sistema é dividido em dois módulos principais, sendo um para cada caso de uso principal (C1 e C2) e um terceiro módulo auxiliar de processamento textual que é utilizado por ambos os módulos principais.

O primeiro módulo principal é relativo ao caso de uso $\mathbf{C 1}$ e seus componentes estão ilustrados e indicados na Figura 8. Esse módulo contempla a coleta e a atualização da coleção de patentes de Bioinformática. Os campos título, resumo, descrição, número da patente, requisitantes, inventores, data de concessão, classe principal e classes secundárias são armazenados em banco de dados. Especificamente os campos textuais livres (título, resumo e descrição) são processados textualmente pelo módulo auxiliar. Os termos resultantes são indexados e armazenados em banco de dados para, posteriormente, serem utilizados no processo de busca.

O segundo módulo principal se refere ao caso de uso C2 e seus componentes estão representados e indicados na Figura 8. Esse módulo é responsável por fazer a interface com o usuário e pelas buscas diretas ou utilizando as informações de classificação como filtro. A interface do usuário permite que sejam consultados termos, frases ou documentos completos, como patentes, artigos científicos e outros. A consulta é processada 
textualmente pelo módulo auxiliar (indicado ao centro na Figura 8) e pode ser expandida com a utilização de uma ontologia. O usuário pode optar por fazer uma busca direta, sem a utilização do classificador, ou efetuar uma busca guiada, utilizando informações de classificação. Por fim, os resultados são exibidos para o usuário.

O módulo auxiliar de processamento textual foi projetado para trabalhar com ambos os módulos principais, pois técnicas como remoção de caracteres especiais e stopwords, stemming, cálculo de frequências e pesos e expansão de termos utilizando ontologia são utilizados em consultas, no processamento e na indexação da coleção de patentes de Bioinformática.

\subsection{Módulos de Processamento Textual, Classificação e Recuperação de Informação do Sistema BPS}

Essa seção aborda a metodologia de utilização dos termos da Gene Ontology no processamento textual e descreve os processos de seleção do classificador e cálculo de similaridades implementados no sistema BPS.

\subsubsection{Identificação de Conceitos de Bioinformática: GO como Artefato Linguístico}

Conforme descrito na Seção 4.3, optou-se pela utilização da Gene Ontology como artefato linguístico, visando a diminuição da dimensionalidade e o aumento da representatividade dos termos encontrados em cada documento de patente. Cada termo ou conceito na Gene Ontology possui um identificador único associado, composto pelo prefixo GO: e seguido por um código numérico, por exemplo, o identificador GO:0008150 corresponde ao conceito Processo Biológico. Esses identificadores são chamados termos $G O$.

A metodologia de identificação dos conceitos de Bioinformática presentes nos textos das patentes possui três etapas: (i) definir qual ferramenta seria utilizada nas buscas por termos GO, (ii) processar os n-gramas obtidos nos textos das patentes e (iii) utilizar os n-gramas nas pesquisas por termos da Gene Ontology.

O Gene Ontology Consortium disponibiliza diferentes ferramentas de acesso aos dados da GO. Dentre elas estão a ferramenta de buscas online AmiGO ${ }^{1}$ acessível pelo site

\footnotetext{
${ }^{1}$ http://amigo.geneontology.org/cgi-bin/amigo/go.cgi
} 
da GO, sistemas de apoio desenvolvidos por parceiros ${ }^{2}$, web service ${ }^{3}$ e a base de dados completa da ontologia ${ }^{4}$. Diante de tais opções, na primeira tarefa optou-se pelas consultas diretas à base de dados da GO, devido ao alto custo computacional característico dos processamentos textuais, especialmente de coleções com grande quantidade de documentos e termos, como é o caso do presente trabalho. Em geral, web services são a solução mais utilizada para integrar sistemas. No entanto, a latência na comunicação com o web services aumentaria consideravelmente o tempo de consulta de cada n-grama. O banco de dados completo da GO foi baixado e instalado localmente em um servidor MySQL.

Na segunda tarefa se fez necessário o processamento dos n-gramas obtidos nos textos de cada documento. A técnica de processamento de n-gramas consiste na decomposição de expressões textuais em sequências de $n$ letras ou palavras. Para exemplificar, a decomposição por letras com $n=2$ para a palavra image resultaria nos bigramas $\{$ im, ma, $a g, g e\}$. Para uma decomposição por palavras, o presente trabalho utilizou as decomposições por bigramas e trigramas, ou seja, $n=\{2,3\}$. Por exemplo, o título de patente "Image processing in microsphere arrays" foi decomposto em $n=2$ e os bigramas $\{$ Image processing, processing in, in microsphere, microsphere arrays $\}$ foram considerados para buscar os conceitos na GO.

Na terceira tarefa foram consultados os termos GO utilizando os termos resultantes do processamento dos n-gramas. As consultas foram efetuadas diretamente no banco de dados e contemplava termos e sinônimos. Os termos GO obtidos foram armazenados com suas respectivas frequências na tabela de termos.

\subsubsection{Avaliação e Escolha do Modelo de Classificação}

Conforme demonstrado na Figura 9, no presente trabalho foi desenvolvido um filtro, modelado segundo o processo de descoberta de conhecimento (KDD - KnowledgeDiscovery in Databases) para guiar as buscas no sistema de patentes. O filtro processa as consultas dos usuários utilizando a Gene Ontology como artefato linguístico e aponta um grau de similaridade entre a consulta do usuário e as classes de Bioinformática. A saída do filtro é um ranking de classes ordenadas, de maneira decrescente, pelo grau de similaridade, ou seja, as classes mais próximas do topo do ranking estão mais relacionadas à consulta do usuário. Em seguida, a função de busca calcula a similaridade da consulta original com cada documento das duas primeiras classes do ranking. Esse procedimento de

\footnotetext{
${ }^{2}$ http://www.geneontology.org/GO.tools.shtml

${ }^{3}$ http://www.ebi.ac.uk/ontology-lookup/WSDLDocumentation.do

${ }^{4}$ http://www.geneontology.org/GO.downloads.database.shtml
} 
visualização, via relacionamentos, visa orientar e diminuir o campo de busca, de maneira que sejam encontrados mais documentos relevantes.

Para a definição do modelo de classificação a ser utilizado no sistema como filtro, se faz necessário adaptar um processo de descoberta de conhecimento (KDD) com etapas bem definidas que permitam avaliar os diferentes classificadores testados. O processo de KDD utilizado no presente trabalho é composto por cinco etapas: (1) Seleção, (2) Pré-processamento, (3) Transformação, (4) Mineração de Texto e (5) Avaliação.

Na Etapa de Seleção (1), foram identificadas as classes USPC que categorizam as tecnologias de bioinformática e a distribuição das classes na coleção utilizada. Após a análise do corpus, o processo de coleta foi iniciado para capturar a visão lógica de cada documento. Primeiramente identificou-se a estrutura dos documentos da coleção, em seguida definiu-se os campos a serem coletados.

Durante a coleta, a Etapa de Pré-processamento (2) dos dados foi iniciada, a qual corresponde às tarefas de eliminação de caracteres especiais e stopwords e a redução de cada termo ao seu radical (stemming). As tarefas de coleta e de pré-processamento são descritas nas Seções 6.1 e 5.3.

A Etapa de Transformação (3) de atributos é efetuada para padronizar os valores, de maneira a normalizá-los e adaptá-los aos classificadores que serão aplicados. Nessa etapa são calculados os pesos de cada termo a partir de suas frequências. O método adotado para o cálculo de pesos foi o $t f^{*} i d f$. De acordo com (BAEZA-YATES; RIBEIRO-NETO, 1999), esse modelo se mostra interessante, pois demonstram a representatividade de cada termo

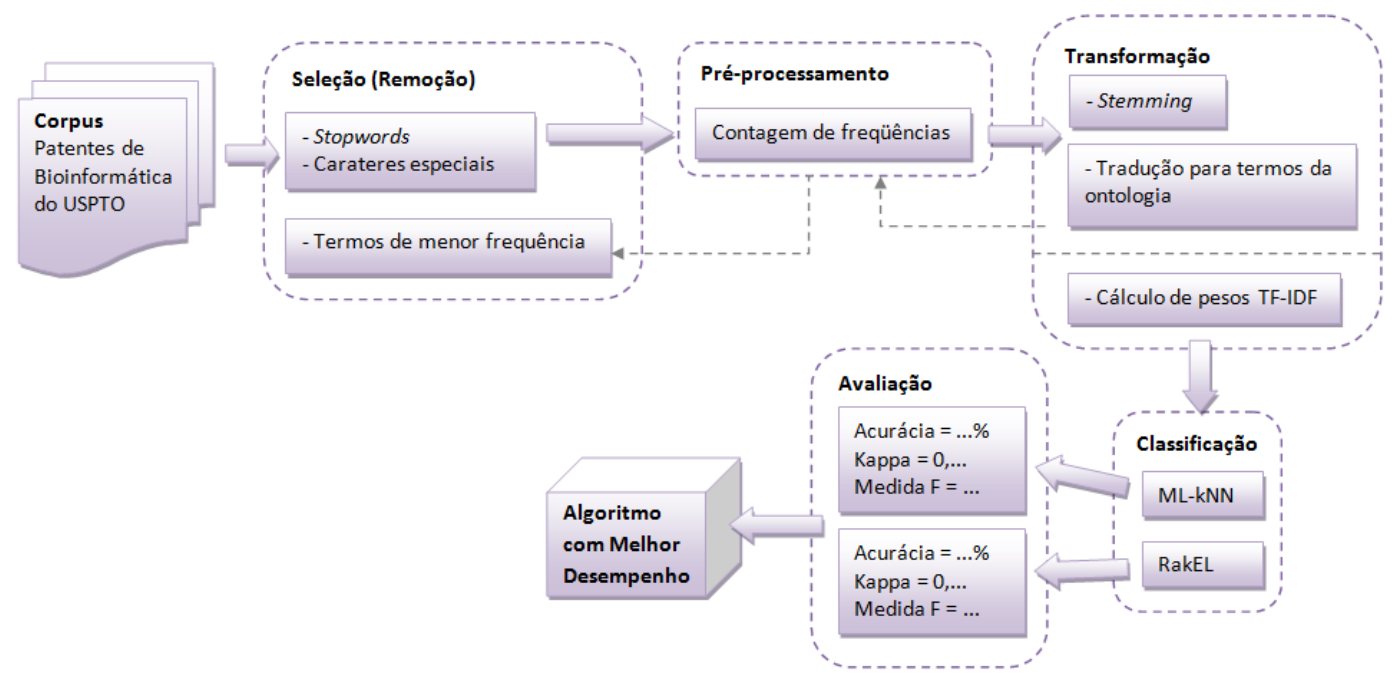

Figura 9: Visão geral do filtro utilizado no sistema de busca guiada de patentes de Bioinformática. 
perante cada documento e perante a coleção como um todo.

Na Etapa de Mineração de Textos (4), para utilizar os dois tipos de classificação preconizados pelo USPTO (obrigatória e arbitrária) foram testados os algoritmos de classificação multirrótulo: Random k-Labelsets (RakEL) e Multilabel k-Nearest Neighbors (ML$\mathrm{kNN}$ ), o qual é baseado no algoritmo único rótulo kNN.

Na Etapa de Avaliação (5), foi utilizada a Validação Cruzada Estratificada de 10 partes, do inglês 10-Fold Cross-Validation Stratified, como método de validação. Esse método divide a coleção de documentos em dez partes mutuamente exclusivas e com a quantidade de exemplos de cada classe proporcional. A cada iteração, nove partes são utilizadas para treinamento e uma parte para teste. As métricas de Acurácia, Hamming Loss, Precisão, Revocação e Medida-F foram utilizadas como medidas de avaliação do classificador.

\subsubsection{Processamento de Similaridades}

De acordo com (BAEZA-YATES; RIBEIRO-NETO, 1999), sistemas de Recuperação de Informação se caracterizam por utilizar técnicas de modelagem de dados, indexação, classificação de textos e interfaces gráficas para disponibilizar aos usuários informações relevantes de maneira fácil. Com base nessas características, o sistema BPS é considerado um sistema de Recuperação de Informação Textual.

O módulo de Recuperação de Informação do sistema BPS utiliza o Modelo Vetorial para efetuar os processamentos de similaridade entre a consulta e os documentos das classes apontadas pelo filtro. Conforme descrito no Capítulo 4, para efetuar o processamento de similaridade, se faz necessário (i) extrair a visão lógica do documento, ou seja, processar textualmente o documento para identificar os termos de índice mais representativos, (ii) calcular a distância da consulta para cada documento da coleção, ou seja, processar a similaridade entre a consulta e cada patente da coleção e (iii) exibir os resultados por ordem decrescente de grau de similaridade.

Como pode ser observado na Figura 10, a etapa (i) do processamento de similaridades utiliza o módulo de processamento textual descrito na Seção 5.3 para traduzir os n-gramas para termos da Gene Ontology, remoção de caracteres especiais e stopwords, redução de palavras ao radical (stemming), remoção de termos com frequência igual à um e cálculo de pesos $t f-i d f$. Na etapa (ii), para medir o grau de similaridade entre a consulta e os documentos, foi utilizado o cálculo do cosseno do ângulo entre o vetor de pesos da consulta 
e os vetores de peso de cada documento da coleção de patentes. Por fim, na etapa (iii) são exibidos os relacionamentos com grau de similaridade maior que 60\%. A interface gráfica permite ao usuário visualizar informações textuais de cada patente do ranking, como URI da patente no site do USPTO, título, resumo, número da patente, classificações USPC e IPC, descrição, data da patente, inventores e requisitantes.

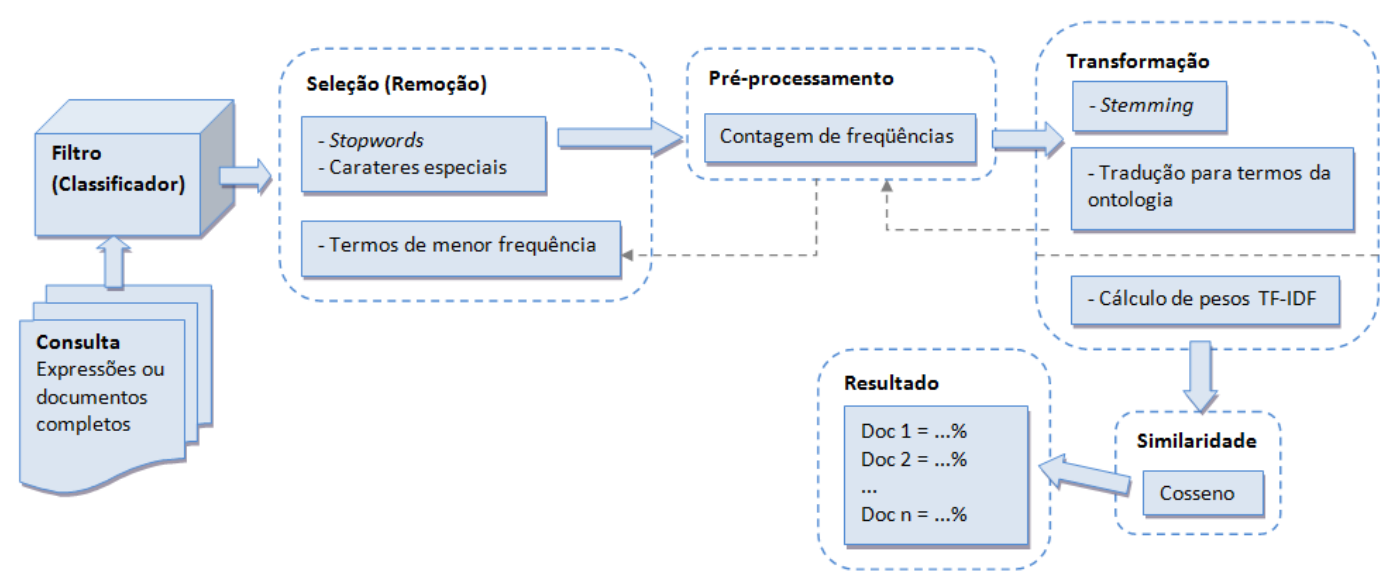

Figura 10: Visão geral do processamento de similaridade do sistema de busca guiada de patentes de Bioinformática.

\subsection{O Sistema BPS}

Conforme citado na Seção 1.1, pequenas e médias empresas brasileiras de pesquisa que precisam fazer buscas por patentes, muitas vezes não podem arcar com os altos custos de uma ferramenta comercial de busca de patentes. Nesse contexto surge o Sistema de Busca Guiada de Patentes de Bioinformática (BPS) desenvolvido neste trabalho, o qual é uma ferramenta gratuita que possui como diferencial o foco na área de Bioinformática e a busca guiada por informações de classificação. Da maneira como foi projetado, o BPS permite ser aplicado à outras áreas do conhecimento. Para isso, o classificador deve ser treinado novamente com uma nova coleção da área que se deseja aplicar o BPS e incorporar a utilização de outro artefato linguístico (ontologia, tesauro, dicionário, etc) também relativo à essa nova área de aplicação.

O BPS foi desenvolvido utilizando tecnologias gratuitas, de código aberto (opensource) e mundialmente reconhecidas, como a plataforma $\mathrm{Java}^{5}$, a linguagem de programação Python ${ }^{6}$ e o banco de dados Postgresql ${ }^{7}$. Para o desenvolvimento do classificador

\footnotetext{
${ }^{5}$ http://java.oracle.com

${ }^{6}$ http://www.python.org

${ }^{7}$ http://www.postgresql.org
} 
foi utilizada a biblioteca de código aberto $\mathrm{Mulan}^{8}$, que implementa algoritmos de classificação multirrótulo e foi desenvolvida sobre a ferramenta open-source Weka ${ }^{9}$. Segundo (TSOUMAKAS et al., 2011b), os criadores da biblioteca Mulan optaram pelo desenvolvimento sobre a Weka, pois a Weka é uma ferramenta de código aberto que implementa diversos algoritmos de aprendizado supervisionado, os quais são a base para algoritmos multirrótulo de transformação do problema. Outro motivo para a utilização da Weka foi sua difusão e aceitação no meio acadêmico. Pesquisadores da área de Aprendizado de Máquina estão familiarizados com a Weka e muitas pesquisas têm sido realizadas utilizando essa ferramenta (TSOUMAKAS et al., 2011b).

Diferentemente de outros sistemas de busca de patentes, o BPS possui um classificador textual que guia as buscas por patentes de Bioinformática, que sugere à quais classes de Bioinformática os termos consultados podem pertencer. Em seguida, o BPS calcula as similaridades da consulta com as patentes das mesmas classes sugeridas pelo classificador exibindo um ranking. Com este processo de classificação, espera-se que mais documentos relacionados à consulta sejam recuperados, dado que as buscas foram direcionadas para o conjunto de patentes da mesma classe de Bioinformática da consulta sugerida pelo sistema.

O Sistema BPS possui duas interfaces $W e b$ do tipo usuário-computador: (i) interface principal de busca, ilustrada pela Figura 11, e a (ii) interface de detalhamento da busca por patente, ilustrada pela Figura 12. Na interface principal as consultas são efetuadas e os rankings de classificação e similaridade com documentos da coleção. Os termos e expressões para busca podem ser submetidos via componente de entrada de texto (input text) ou via carregamento de arquivo-texto que contenha os termos da busca. No momento da consulta, o usuário pode optar por busca classificada marcando a opção Classificar e pode optar por utilizar os termos da Gene Ontology no processamento de similaridades ao marcar a opção Utilizar GO.

O ranking de classificação exibe as classes USPC de Bioinformática e o grau de similaridade entre os termos pesquisados e as classes. Os resultados são apresentados em uma tabela por ordem decrescente de similaridade. Os resultados das buscas também são exibidos por ordem de similaridade, mas em uma tabela com o código identificador da patente no BPS, número da patente, título, classes USPC e grau de similaridade. A tabela de resultados de busca exibe na última coluna à direita um botão de visualização que redireciona para a tela de detalhes da patente.

\footnotetext{
${ }^{8}$ http://mulan.sourceforge.net

${ }^{9}$ http://www.cs.waikato.ac.nz/ml/weka
} 


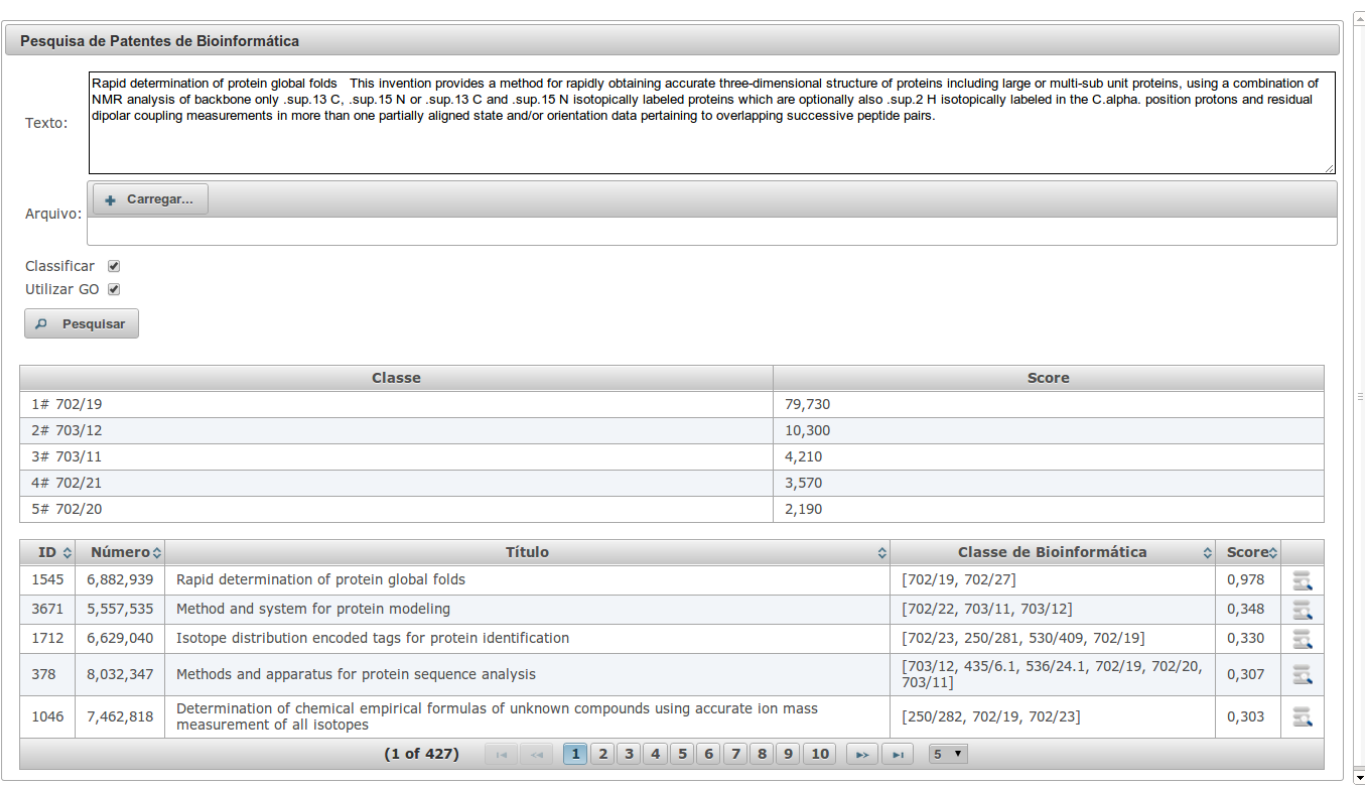

Figura 11: Interface de pesquisa de patentes do sistema BPS.

A interface gráfica de detalhamento da busca exibe o número da patente, o título, a data da patente, o resumo e a classificação completa USPC em uma lista. É possível retornar à tela principal pelo botão Voltar. O título da patente é configurado como uma hiperligação para o documento original na base de patentes do USPTO.

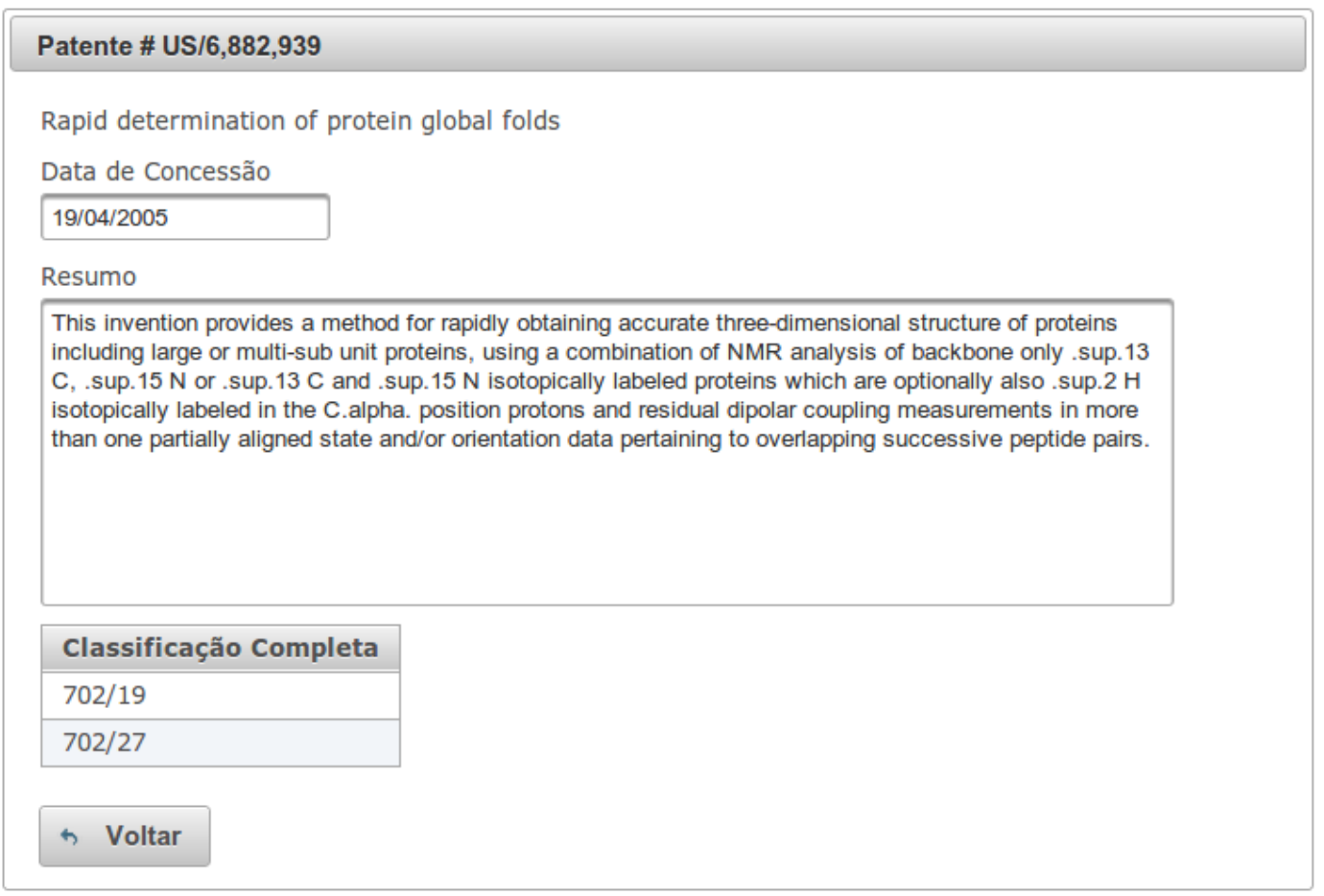

Figura 12: Interface de visualização dos detalhes da patente. 


\section{Experimentações e Resultados}

Este capítulo apresenta os experimentos realizados para analisar os resultados do sistema BPS. A Seção 6.1 descreve a coleção utilizada nos experimentos. A Seção 6.2 apresenta os experimentos realizados para avaliar algoritmos de classificação e escolher qual deles seria utilizado no componente de classificação para guiar as buscas no sistema BPS. Na Seção 6.3 são apresentados os experimentos que avaliam os resultados obtidos no processo de Recuperação de Informação, ou seja, no processo de busca guiada de patentes de Bioinformática implementado no sistema BPS.

\subsection{O Repositório de Patentes}

A coleção de patentes utilizada no repositório do presente trabalho foi obtida no site do escritório americano de patentes. Para coletar os documentos foi desenvolvido um web crawler $^{1}$, que acessa a página de buscas avançadas do USPTO ${ }^{2}$, processa as páginas HTML e coleta automaticamente as informações textuais de cada patente de Bioinformática. Para realizar os experimentos descritos por esta dissertação, optou-se por trabalhar com uma coleção fixa de documentos que foram coletados até outubro de 2012. A partir outubro de 2012, iniciou-se a implementação dos módulos do sistema e experimentações. A fixação da coleção foi necessária para sistematizar e avaliar os resultados obtidos nos experimentos.

Segundo o editorial publicado na página do USPTO, a divulgação de um documento de patente segue os termos de concessão pré-estabelecidos por órgãos competentes. Dada a característica intrínseca das patentes de difundir o conhecimento humano, os termos de concessão garantem que os textos das patentes divulgados no site do USPTO não estão sujeitos à restrições de copyright. O escritório americano preconiza que em casos

\footnotetext{
${ }^{1}$ Web crawlers são máquinas de busca que coletam informações textuais em sites pela Internet. Esses agentes percorrem recursivamente as hiperligações (hyperlinks) existentes na página atual em busca de novas páginas web para coletar (BAEZA-YATES; RIBEIRO-NETO, 1999).

${ }^{2}$ http://patft.uspto.gov/netahtml/PTO/search-adv.htm
} 
de utilização de informações obtidas em sua página, estas sejam devidamente referenciadas (USPTO, 2013a). O presente trabalho se apoia nessas definições para acessar e coletar as patentes publicadas no site do USPTO. Os autores esclarecem que no âmbito deste trabalho a utilização dessas informações coletadas não são para fins comerciais, mas exclusivamente para uso acadêmico.

Para coletar as patentes, o webcrawler desenvolvido acessou a página de busca avançada de patentes do USPTO e efetuou buscas informando cada uma das cinco classificações americanas reservadas para Bioinformática. Cada busca retornou uma série de links para os documentos de patentes completos. O webcrawler acessou cada link retornado e coletou todas as patentes de Bioinformática que possuíssem classificação obrigatória ou auxiliar correspondentes aos argumentos da pesquisa. Isso se deve ao fato de que a ferramenta de pesquisa disponibilizada pelo USPTO não possibilita buscas somente por classes obrigatórias ou somente por classes auxiliares. Assim, uma pesquisa por patentes classificadas como $702 / 19$, por exemplo, pode retornar documentos também classificados por outros grupos, como $703 / 11,702 / 21$, etc.

Para pesquisas por classe, a sequência 'CCL/' seguida pelo código da classe deve ser informada. Assim, os termos das pesquisas e a quantidade de registros retornada foram, respectivamente, 'CCL/702/19', a qual retornou 1.951 registros, 'CCL/702/20', que obteve 696 registros, 'CCL/702/21', que retornou 144 documentos, 'CCL/703/11', que obteve 703 registros e 'CCL/703/12', que retornou 240 documentos. No total foram coletadas 2.863 documentos de patentes. O gráfico da Figura 13 ilustra a distribuição de patentes pelas classes USPC de Bioinformática. Quanto às palavras e termos, a coleção apresenta 10.518 palavras únicas, 6.267 termos únicos processados e 99 termos únicos obtidos na Gene Ontology. Na Seção 5.3 são detalhados quais campos das patentes foram coletados e processados.

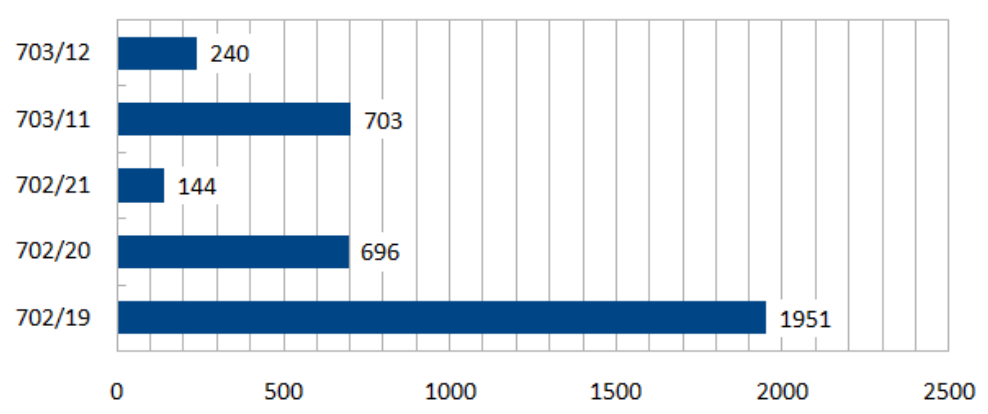

Figura 13: Distribuição de documentos por classes de Bioinformática. 


\subsection{Experimento I: Componente de Classificação}

O experimento descrito nesta seção foi elaborado com o objetivo de escolher um classificador para compor o filtro do sistema BPS. Para isso, a partir do repositório de patentes de Bioinformática descrito na Seção 6.1 foram geradas coleções que combinavam diferentes características e, para cada coleção, foram aplicados algoritmos de classificação multirrótulo com diferentes parametrizações. Os resultados obtidos foram avaliados e comparados, visando identificar qual combinação de coleção, algoritmo e parâmetros apresentou o melhor desempenho. As subseções a seguir descrevem a preparação e os resultados obtidos.

\subsubsection{Preparação}

Conforme detalhado na Tabela 7, foram preparadas 16 coleções que combinavam diferentes características. Metade das coleções foi composta exclusivamente pelos termos originais do título e resumo das patentes pré-processados e a outra foi composta por termos da Gene Ontology. Nas coleções que utilizaram a GO, os bigramas e trigramas originais foram substituídos pelos termos GO correspondentes. Como métodos de atribuição de peso, oito coleções utilizaram a frequência de cada termo e as outras oito, a estratégia de ponderação $t f^{*} i d f$. Oito coleções foram compostas por termos com frequência mínima igual à 5 e as outras oito não exigiram frequência mínima. Quatro coleções foram compostas por termos com frequência máxima igual à 80, outras quatro coleções com frequência máxima de 40 e o restante não houve limitação máxima de frequência.

As coleções utilizadas para teste e avaliação dos classificadores apresentam a mesma distribuição de exemplos por classes verificadas na área atualmente, ou seja, mesmo que

\begin{tabular}{lcccc} 
Coleção & Termos & $\begin{array}{c}\text { Método de } \\
\text { Peso }\end{array}$ & $\begin{array}{c}\text { Frequência } \\
\text { Mínima }\end{array}$ & $\begin{array}{c}\text { Frequência } \\
\text { Máxima }\end{array}$ \\
\hline multilabel_go_min_1 & Gene Ontology & Frequência & 1 & - \\
multilabel_go_min_5 & Gene Ontology & Frequência & 5 & - \\
multilabel_go_min_5_max_80 & Gene Ontology & Frequência & 5 & 80 \\
multilabel_go_min_5_max_40 & Gene Ontology & Frequência & 5 & 40 \\
multilabel_go_tfidf_min_1 & Gene Ontology & tf*idf & 1 & - \\
multilabel_go_tfidf_min_5 & Gene Ontology & tf*idf & 5 & - \\
multilabel_go_tfidf_min_5_max_80 & Gene Ontology & tf*idf & 5 & 80 \\
multilabel_go_tfidf_min_5_max_40 & Gene Ontology & tf*idf & 5 & 40 \\
multilabel_min_1 & Originais & Frequência & 1 & - \\
multilabel_min_1_max_80 & Originais & Frequência & 1 & 80 \\
multilabel_min_1_max_40 & Originais & Frequência & 1 & 40 \\
multilabel_min_5 & Originais & Frequência & 5 & - \\
multilabel_tfidf_min_1 & Originais & tf*idf & 1 & - \\
multilabel_tfidf_min_1_max_80 & Originais & tf*idf & 1 & 80 \\
multilabel_tfidf_min_1_max_40 & Originais & tf*idf & 1 & 40 \\
multilabel_tfidf_min_5 & Originais & tf*idf & 5 & -
\end{tabular}

Tabela 7: Coleções utilizadas na análise dos classificadores. 
desbalanceadas, as coleções representam a realidade atual e não foram equalizadas em termos de quantidade de exemplos por classe. Portanto, todas a coleções utilizadas nos experimentos descritos a seguir seguem a mesma distribuição de exemplos por classe apresentada na Seção 6.1.

Para cada coleção foram aplicados os algoritmos de classificação multirrótulo citados em (TSOUMAKAS et al., 2011a) ML-kNN (Multi-Label k-Nearest Neighbors) e RakEL (RAndom k-LabELsets) com diferentes parametrizações com o objetivo de identificar os algoritmos e parâmetros com melhor desempenho. O ML-kNN é uma adaptação do algoritmo único rótulo $k$ - $N N$ e foi executado em três iterações com $k=\{1,3,5\}$. Já o RakEL (RAndom k-LabELsets), conforme descrito na Seção 3.1.1, consiste em uma abordagem de Transformação do Problema que utiliza como base um algoritmo único rótulo. Para o presente trabalho optou-se por avaliar a execução do RakEL em combinação com o algoritmo Support Vector Machines (SVM) com os valores do parâmetro de complexidade $c=\{0.1,1,10\}$ e com o algoritmo Naive Bayes Multinomial, o qual não possui parametrizações.

Cada iteração foi executada segundo o método de validação 10-Fold Cross-Validation Stratified. As métricas de avaliação observadas foram Hamming Loss, Acurácia e a média das medidas de Precisão, Revocação e Medida-F obtidos por Micro e Macro-Averaging. Os experimentos foram realizados utilizando-se a ferramenta Mulan ${ }^{3}$, a qual utiliza as implementações de algoritmos único rótulo da ferramenta Weka.

\subsubsection{Resultados}

A Tabela 8 apresenta um resumo dos melhores valores de cada medida de avaliação obtidas nos experimentos de classificação. Com o objetivo de comparar o desempenho da utilização dos termos originais e termos GO, a Tabela 8 apresenta duas linhas para cada métrica, sendo uma com o melhor valor obtido em uma coleção que utiliza termos originais pré-processados e a outra que utiliza termos da Gene Ontology. As colunas estão organizadas em três grupos, sendo um para cada algoritmo. As colunas exibidas em cada agrupamento são (i) o parâmetro do algoritmo aplicado àquela coleção, (ii) a coleção em que foi obtido o melhor valor para a métrica e (iii) o valor da métrica. O agrupamento do algoritmo RAkEL(NBM) não apresenta a coluna de parâmetros, pois não foram utilizados parâmetros diferentes para este algoritmo.

\footnotetext{
${ }^{3}$ http://mulan.sourceforge.net
} 
Como se pode observar na Tabela 8, nenhuma coleção com limitante máximo apresentou melhoria no desempenho dos classificadores analisados. Para algoritmos RAkEL com SVM aplicados nessas coleções, os valores de Hamming Loss continuaram acima de $22 \%$ e RAkEL com NBM e ML-kNN mantiveram os mesmos patamares.

Conforme exibido na Tabela 8, as coleções que utilizaram a estratégia de ponderação $t f^{*} i d f$ como método de atribuição de peso apresentaram os menores valores de Hamming Loss. Para Acurácia, apenas uma coleção, que utilizou a Frequência bruta dos termos como peso, apresentou maior valor. Consideradas essas duas medidas, o algoritmo que obteve o melhor desempenho foi o RAkEL com o Naive Bayes Multinomial (NBM), com 16,75\% de Hamming Loss e 60,16\% de Acurácia, ambos observados na coleção multilabel_tfidf_min_1, a qual utilizou pesos calculados por $t f^{*} i d f$, não delimitou a frequência mínima dos termos e utilizou os termos originais pré-processados. As coleções com termos GO apresentaram valores de Hamming Loss e Acurácia inferiores às coleções que utilizaram os termos originais.

A análise das medidas de Precisão, Revocação e Medida-F em Macro-Averaging, apresentadas nas linhas da Tabela 8, também demonstraram melhor desempenho nas coleções com termos originais. As coleções com termos GO obtiveram Medida-F entre 15 e 20 pontos a menos nas execuções do algoritmo RAkEL e em torno de 7 pontos a menos no algoritmo ML-kNN. O algoritmo RAkEL com SVM apresentou o maior valor de Revocação com o valor de $c=0.1$ e aplicado à coleção multilabel_min_1, a qual não limitou os termos em frequência e utilizou a Frequência bruta dos termos como peso. Na mesma coleção foram obtidos os melhores valores do algoritmo RAkEL com NBM que apresentou 57,01\% de Medida-F e 58,66\% de Revocação. O algoritmo RAkEL com NBM quando

\begin{tabular}{|c|c|c|c|c|c|c|c|c|c|}
\hline \multirow[b]{2}{*}{ Métrica } & \multirow[b]{2}{*}{ Termo } & \multicolumn{2}{|l|}{ RAkEL(NBM) } & \multicolumn{3}{|c|}{ RAkEL(SVM) } & \multicolumn{3}{|c|}{ ML-kNN } \\
\hline & & Coleção & Valor & Parâmetro & Coleção & Valor & Parâmetro & Coleção & Valor \\
\hline \multirow{2}{*}{\begin{tabular}{|l} 
Hamming \\
Loss
\end{tabular}} & Original & multilabel_tfidf_min_1 & $16,75 \%$ & $c=0.1$ & multilabel_tfidf_min_5 & $20,41 \%$ & $k=3$ & multilabel_tfidf_min_1 & $17,97 \%$ \\
\hline & GO & multilabel_go_tfidf_min_5 & $9,70 \%$ & $c=0.1$ & multilabel_go_tfidf_min_5 & $22,42 \%$ & $k=1$ & multilabel_go_tfidf_min_5 & $18,83 \%$ \\
\hline \multirow{2}{*}{ Acurácia } & Original & multilabel_tfidf_min_1 &, $16 \%$ & $c=0.1$ & multilabel_tfidf_min_1 & $57,17 \%$ & $k=5$ & multilabel_tfidf_min_5 & $55,74 \%$ \\
\hline & GO & multilabel_go_tfidf_min_5 & $52,78 \%$ & $c=0.1$ & multilabel_go_min_5 & $50,12 \%$ & $k=5$ & multilabel_go_tfidf_min_5 & $54,40 \%$ \\
\hline \multirow{2}{*}{\begin{tabular}{|l} 
Medida-F \\
MACRO
\end{tabular}} & Original & multilabel_min_1 & $7,01 \%$ & $c=0.1$ & multilabel_tfidf_min_1 & $51,37 \%$ & $k=3$ & multilabel_tfidf_min_1 & $27,84 \%$ \\
\hline & GO & multilabel_go_min_5 & & & multilabel_go_min_1 & $37,58 \%$ & & multilabel_go_tfidf_min_5 & $20,64 \%$ \\
\hline \multirow{2}{*}{$\begin{array}{l}\text { Precisão } \\
\text { MACRO }\end{array}$} & Original & multilabel_tfidf_min_1 & $62,11 \%$ & $c=10$ & multilabel_tfidf_min_1 & $49,14 \%$ & $k=5$ & multilabel_tfidf_min_1 & $49,42 \%$ \\
\hline & GO & multilabel_go_tfidf_min_5 & $45,54 \%$ & $c=0.1$ & multilabel_go_tfidf_min_5 & $35,07 \%$ & $k=3$ & multilabel_go_min_1 & $28,46 \%$ \\
\hline \multirow{2}{*}{\begin{tabular}{|l} 
Revocação \\
MACRO
\end{tabular}} & Original & multilabel_min_1 & $58,66 \%$ & $c=0.1$ & multilabel_min_1 & $63,77 \%$ & $k=5$ & multilabel_tfidf_min_1 & $26,69 \%$ \\
\hline & Go & multilabel_go_min_1 & $51,86 \%$ & $c=1$ & multilabel_go_tfidf_min_1 & $45,31 \%$ & $k=5$ & multilabel_go_tfidf_min_5 & $23,29 \%$ \\
\hline \multirow{2}{*}{$\begin{array}{l}\text { Medida-F } \\
\text { micro }\end{array}$} & Original & multilabel_min_1 & $67,97 \%$ & $c=0.1$ & multilabel_tfidf_min_1 & $64,50 \%$ & $k=3$ & multilabel_tfidf_min_3 & $62,25 \%$ \\
\hline & Go & multilabel_go_tfidf_min_5 & $58,79 \%$ & $c=0.1$ & multilabel_go_tfidf_min_5 & $56,59 \%$ & $k=5$ & multilabel_go_tfidf_min_5 & $60,29 \%$ \\
\hline \multirow{2}{*}{\begin{tabular}{|l} 
Precisão \\
micro
\end{tabular}} & Original & multilabel_tfidf_min_1 & $69,20 \%$ & $c=0.1$ & multilabel_tfidf_min_5 & $60,94 \%$ & $k=3$ & multilabel_tfidf_min_1 & $69,64 \%$ \\
\hline & Go & multilabel_go_tfidf_min_5 & $64,71 \%$ & $c=0.1$ & multilabel_go_min_5 & $57,81 \%$ & $k=1$ & multilabel_go_tfidf_min_5 & $68,15 \%$ \\
\hline \multirow{2}{*}{\begin{tabular}{|l} 
Revocação \\
micro
\end{tabular}} & Original & multilabel_min_1 & & $c=0.1$ & multilabel_min_1 & $71,30 \%$ & $k=5$ & multilabel_tfidf_min_5 & $56,44 \%$ \\
\hline & GO & multilabel_go_min_1 & $58,48 \%$ & $c=10$ & multilabel_go_tfidf_min_1 & $61,34 \%$ & $k=5$ & multilabel_go_min_5 & $54,44 \%$ \\
\hline
\end{tabular}

Tabela 8: Resumo dos algoritmos com melhores valores para cada métrica observada. 
aplicado à coleção multilabel_tfidf_min_1 obteve o melhor valor de Precisão com 62,11\%.

Conforme observado na Seção 6.1, a densidade de exemplos das classes utilizadas nos experimentos é desbalanceada, ou seja, determinadas classes apresentam muito mais termos do que outras, como é o caso das classes 702/19 com 1.951 exemplos e 702/21 com 144 instâncias. Como pode ser observado na Tabela 8, devido à essa característica, os valores obtidos por Micro-averaging são maiores que os Macro-averaging.

Na análise dos valores obtidos em Micro-Averaging, os valores obtidos em coleções que utilizaram termos GO ficaram mais próximos das coleções que utilizaram os termos originais. Destaca-se o valor de Precisão de 68,15\% obtido pelo algoritmo ML-kNN com $k=1$ e aplicado à coleção multilabel_go_tfidf_min_5, a qual utilizou $t f^{*} i d f$ como peso e limitou a frequência mínima dos termos em 5. O valor obtido nessa iteração ficou muito próximo dos melhores valores de Precisão que foram 69,94\% obtido também pelo algoritmo ML-kNN com $k=3$ e 69,20\% obtido pelo RAkEL com NBM, ambos aplicados à coleção multilabel_tfidf_min_1. Mais uma vez, de maneira geral o algoritmo RAkEL com NBM apresentou as melhores medidas com Medida-F igual 67,97\% e Revocação 71,12\%, muito próximo do máximo 71,30\% obtido pelo RAkEL com SVM.

De acordo com as análises efetuadas, o algoritmo RAkEL com NBM demonstrou os melhores valores entre os algoritmos analisados, especialmente quando aplicados às coleções multilabel_min_1 e multilabel_tfidf_min_1, as quais utilizaram os termos originais pré-processados sem limitação mínima de frequência dos termos. A única diferença entre as coleções está no método de atribuição de pesos, onde a primeira coleção utiliza a Frequência bruta dos termos e a segunda utiliza a estratégia de ponderação $t f^{*} i d f$. A Tabela 9 exibe um comparativo entre os valores das medidas encontradas nas duas coleções. O melhor valor para Hamming Loss foi obtido na coleção multilabel_tfidf_min_1 com 16,75\%. Entretanto, a diferença para a coleção multilabel_min_1 é menor que 0,8\%. A Acurácia das duas coleções se apresentaram ainda mais próximas com uma diferença de $0,2 \%$. As maiores diferenças entre as medidas das duas coleções foram observadas na Medida-F e Revocação em Macro-Averaging com 11,97\% e 18,12\%, respectivamente. As maiores medidas Macro foram obtidas na coleção multilabel_min_1, com $58,66 \%$ de Revocação e $57,01 \%$ de Medida-F.

As análises demonstraram que o algoritmo RAkEL com NBM aplicado à coleção multilabel_min_1 se mostra a melhor opção para compor o filtro do sistema BPS. A diferença do Hamming Loss e Acurácia da coleção multilabel_min_1 para a coleção multilabel_tfidf_min_1 são pequenas e os valores encontrados ainda são melhores que os 
obtidos nos outros experimentos. As medidas Macro, as quais são mais importantes em coleções desbalanceadas, como as coleções do presente trabalho, apresentaram valores maiores de Revocação e Medida-F para multilabel_min_1. Apesar da Precisão Macro da coleção multilabel_tfidf_min_1 ter se mostrado superior, a Precisão da coleção multilabel_min_1 se mostrou mais balanceada em relação à Revocação. Outro fator que contribuiu para a escolha da coleção multilabel_min_1 é o esquema de atribuição de peso por Frequência bruta dos termos. Como os pesos de cada termo não são dados pelo cálculo do $t f^{*} i d f$, a atualização da coleção não requer o reprocessamento completo de todos os documentos.

Pesquisas recentes demonstram que, em geral, a utilização de artefatos linguísticos, como ontologias, melhoram o desempenho de classificadores automáticos de patentes (LUPU et al., 2011). No entanto, os experimentos realizados não conseguiram identificar o aprimoramento da classificação com o uso da semântica adicional da Gene Ontology. Essa característica pode ser em decorrência dos termos GO serem muito específicos e apresentarem muitos termos não significativos para patentes, ou seja, os termos indexados pela GO são pouco utilizados na redação de patentes. Para dar continuidade ao desenvolvimento do sistema BPS, até o momento da elaboração desta dissertação, optou-se por utilizar a coleção com termos originais. Entretanto, os termos da Gene Ontology e seu método de utilização serão revisados e melhor analisados em trabalhos futuros.

\begin{tabular}{|c|c|c|c|c|}
\hline & \multicolumn{4}{|c|}{ RAkEL - NBM } \\
\hline & Métrica & $\Delta$ & Valor & Coleção \\
\hline & \multirow{2}{*}{ Hamming Loss } & \multirow{2}{*}{$0,74 \%$} & $17,49 \%$ & multilabel_min_1 \\
\hline & & & $16,75 \%$ & multilabel_tfidf_min_1 \\
\hline & \multirow{2}{*}{ Acurácia } & \multirow{2}{*}{$-0,20 \%$} & $59,96 \%$ & multilabel_min_1 \\
\hline & & & $60,16 \%$ & multilabel_tfidf_min_1 \\
\hline \multirow{6}{*}{ 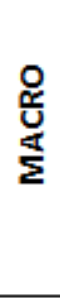 } & \multirow{2}{*}{ Precisão } & \multirow{2}{*}{$-5,35 \%$} & $56,76 \%$ & multilabel_min_1 \\
\hline & & & $62,11 \%$ & multilabel_tfidf_min_1 \\
\hline & \multirow{2}{*}{ Revocação } & \multirow{2}{*}{$18,12 \%$} & $58,66 \%$ & multilabel_min_1 \\
\hline & & & $40,54 \%$ & multilabel_tfidf_min_1 \\
\hline & \multirow{2}{*}{ Medida-F } & \multirow{2}{*}{$11,97 \%$} & $57,01 \%$ & multilabel_min_1 \\
\hline & & & $45,04 \%$ & multilabel_tfidf_min_1 \\
\hline \multirow{5}{*}{ 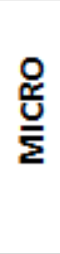 } & \multirow{2}{*}{ Precisão } & \multirow{2}{*}{$-4,07 \%$} & $65,13 \%$ & multilabel_min_1 \\
\hline & & & $69,20 \%$ & multilabel_tfidf_min_1 \\
\hline & \multirow{2}{*}{ Revocação } & \multirow{2}{*}{$6,60 \%$} & $71,12 \%$ & multilabel_min_1 \\
\hline & & & $64,52 \%$ & multilabel_tfidf_min_1 \\
\hline & Medida-F & $1,21 \%$ & $\begin{array}{l}67,97 \% \\
66,76 \%\end{array}$ & $\begin{array}{l}\text { multilabel_min_1 } \\
\text { multilabel_tfidf_min_1 }\end{array}$ \\
\hline
\end{tabular}

Tabela 9: Resumo dos melhores valores obtidos pelo algoritmo RAkEL com NBM. 


\subsection{Experimento II: Componentes de Classificação e Recuperação de Informação}

O processo de avaliação de sistemas de Recuperação de Informação consiste em comparar os relacionamentos apontados pelo sistema com os relacionamentos descritos em uma coleção de referência. A composição de uma coleção de referência requer que especialistas de domínio avaliem previamente a relevância dos relacionamentos nela contido. Não era objetivo do presente trabalho, inclusive por não existir tempo hábil e recurso necessário para formar uma equipe, sistematizar um experimento e avaliar os resultados da busca para montar uma coleção de referência na área de patentes de Bioinformática. No entanto, com o objetivo de efetuar uma avaliação das funcionalidades de Recuperação de Informação do sistema BPS, optou-se por comparar os resultados obtidos pelo BPS com algumas ferramentas de busca de patentes disponíveis. Os resultados foram avaliados em termos de precisão.

Conforme citado no início deste trabalho, pequenas e médias empresas de pesquisa brasileiras, em geral, não podem arcar com o custo de ferramentas comerciais mais completas e com mais recursos para realizarem buscas por anterioridade antes de efetuarem o depósito de uma patente. Com isso, muitas vezes esses interessados acabam recorrendo às ferramentas gratuitas disponíveis na Internet. Diante desse cenário, o experimento descrito nessa seção visa: (i) reproduzir o ambiente que esses interessados encontram gratuitamente na Internet, ou seja, ferramentas genéricas, gratuitas e com menos recursos do que sistemas comerciais e (ii) comparar essas ferramentas com o BPS em termos de precisão em buscas por patentes de Bioinformática.

As ferramentas gratuitas selecionadas para o experimento foram o Patent Full-Text and Image Database ${ }^{4}$ (PatFT) do USPTO, o Patentscope ${ }^{5}$ da WIPO e o Google Patent Search $^{6}$. Essa escolha se deve ao fato de serem importantes sistemas de busca gratuitos utilizados mundialmente. As três ferramentas podem ser acessadas pela Internet por qualquer pessoa interessada em busca de patentes e, assim como a coleção de patentes de Bioinformática do BPS (vide Seção 6.1), esses sistemas abrangem a coleção americana de patentes. A única ferramenta comercial selecionada foi o Derwent Innovations Index $^{7}$ (DII), o qual é reconhecido internacionalmente como importante ferramenta de busca de patentes e, assim como as outras ferramentas selecionadas, abrange a coleção

\footnotetext{
${ }^{4}$ http://patft.uspto.gov

${ }^{5}$ http://patentscope.wipo.int

${ }^{6}$ http://www.google.com/patent

${ }^{7}$ http://wokinfo.com/products_tools/multidisciplinary/dii
} 
americana de patentes. Dessa maneira, utilizando ferramentas importantes e reconhecidas mundialmente, esperava-se obter comparações relevantes com o sistema BPS.

\subsubsection{Preparação}

Para executar os experimentos, foram selecionados aleatoriamente cinco documentos entre todas as patentes que estavam classificadas em apenas uma das cinco classes USPC de Bioinformática da coleção de patentes apresentada na Seção 6.1, de maneira a obter um representante de cada classe de Bioinformática. Em seguida, para compor os textos das buscas, o título e o resumo de cada documento foram analisados e as palavras que não agregavam representatividade, por exemplo, stopwords (artigos, preposições, etc) foram excluídas.

Cada ferramenta apresenta limitações diferentes quanto ao número de termos e caracteres de busca, por exemplo, o PatFT limita as consultas à 256 caracteres, o Google Patents à 32 palavras e o Patentscope e o Derwent não limitam a quantidade de termos ou caracteres de busca. Devido à essas características, para uma comparação mais justa, se fez necessário equiparar a quantidade de termos de busca até o limite em que o mesmo conjunto de termos pudesse ser utilizado como entrada para as buscas em todas as ferramentas. Assim, os termos de entrada tiveram que ser limitados até o máximo de 256 caracteres.

Outra medida tomada para reproduzir as mesmas condições de busca em todas ferramentas, foi delimitar o campo de busca apenas às patentes americanas de Bioinformática. Nesse contexto, a comparação por precisão foi feita apenas entre as ferramentas PatFT, Google Patents e BPS. Os sistemas Patentscope e Derwent, apesar de também indexarem a coleção de patentes americana, não permitem delimitar as buscas por classes americanas USPC. A exibição dos seus resultados das buscas foi mantida a título de demonstração do processo de busca nessas ferramentas. Com isso, as buscas no Patentscope e no Derwent tiveram que ser filtradas pelas classes internacionais IPC de Bioinformática ${ }^{8}$.

A seguir são exibidos os documentos utilizados nas buscas, bem como as respectivas classes de Bioinformática, número, título, resumo das patentes e o conjunto de termos utilizados nas buscas. Cada documento foi identificado com um número de 1 a 5 que é utilizado para referenciar a patente nas análises descritas nesta seção.

Documento: $\# 1$

\footnotetext{
${ }^{8}$ http://web2.wipo.int/ipcpub/ $\#$ refresh=symbol\&notion=scheme\&symbol=G06F0019100000
} 
Classe: $702 / 19$

Número - Título: US6882939 - Rapid determination of protein global folds

Resumo: This invention provides a method for rapidly obtaining accurate three-dimensional structure of proteins including large or multi-sub unit proteins, using a combination of NMR analysis of backbone only .sup.13 C, .sup.15 N or .sup.13 C and .sup.15 N isotopically labeled proteins which are optionally also .sup.2 H isotopically labeled in the C.alpha. position protons and residual dipolar coupling measurements in more than one partially aligned state and/or orientation data pertaining to overlapping successive peptide pairs.

Termos selecionados para busca: protein global folds obtaining accurate three-dimensional structure large multi-sub unit NMR isotopically protons residual dipolar coupling

Documento: $\# 2$

Classe: $702 / 20$

Número - Título: US8296075 - Computer system and computer-facilitated method for nucleic acid sequence alignment and analysis

Resumo: The present invention relates to a computer system and methods of computerfacilitated data analysis for providing reliable DNA alignments. More specifically, the invention relates to the automation of alignment and naming of mitochondrial DNA sequences for use in forensic analysis. The methods of the present invention provide consistency of sequence nomenclature by minimizing alignment ambiguities, thus providing a common functional system within and among laboratories.

Termos selecionados para busca: computer nucleic acid sequence analysis naming mitochondrial DNA sequences forensic consistency nomenclature ambiguities laboratories

Documento: $\# 3$

Classe: $702 / 21$

Número - Título: US4063309 - Mean corpuscular volume measuring apparatus and method

Resumo: Apparatus and method are provided for determining mean corpuscular volume of cells in a sample passing through a conductivity cell. A coincidence corrected red blood cell count is generated by conventional means, and a signal indicative of hematocrit level is provided. A digital representation of the corrected red blood cell 
count is loaded into a register connected to comparator means. A digital output generated in response to the hematocrit level indicated by the hematocrit signal is utilized as a clock pulse train. The clock pulse train has a total length indicative of the hematocrit level, or a multiple thereof. The count indicated by the clock pulse train is compared by the comparator means, which acts as a divider, to the red blood cell count. The output of the comparator means comprises a digital number which is indicative of the mean corpuscular volume of a sample.

Termos selecionados para busca: apparatus corpuscular volume conductivity red blood cell hematocrit loaded register comparator digital response clock pulse train clock pulse divider

Documento: \#4

Classe: $703 / 11$

Número - Título: US8271250 - Molecule design support apparatus and computer-readable storage medium

Resumo: A molecule design support apparatus has an input part, a display to display on a screen thereof a three-dimensional molecular structure by a half vector format or a ball-and-stick format, and a determining part to determine, in the molecular structure, an end that is to become a target of a coordinate modification with respect to a molecule in its entirety, in response to a bond axis of the molecule specified from the input part. The apparatus further has a modifying part to make a modification of the molecular structure based on the specified bond axis and the end that is the target of the coordinate modification, in response to the modification specified from the input part, and a display part to display a modified molecular structure on the screen of the display based on a determination made by the determining part and the modification made by the modifying part.

Termos selecionados para busca: computer-readable storage molecule support apparatus input display three-dimensional structure vector ball-and-stick format coordinate modification bond axis

Documento: $\# 5$

Classe: $703 / 12$

Número - Título: US8271251 - Automated imaging system for single molecules 
Resumo: There is provided a high throughput automated single molecule image collection and processing system that requires minimal initial user input. The unique features embodied in the present disclosure allow automated collection and initial processing of optical images of single molecules and their assemblies. Correct focus may be automatically maintained while images are collected. Uneven illumination in fluorescence microscopy is accounted for, and an overall robust imaging operation is provided yielding individual images prepared for further processing in external systems. Embodiments described herein are useful in studies of any macromolecules such as DNA, RNA, peptides and proteins. The automated image collection and processing system and method of same may be implemented and deployed over a computer network, and may be ergonomically optimized to facilitate user interaction.

Termos selecionados para busca: throughput molecule image collection optical focus illumination fluorescence microscopy macromolecules DNA RNA peptides proteins network ergonomically user interaction

\subsubsection{Resultados das Classificações}

Conforme citado anteriormente, o sistema BPS utiliza um classificador textual como filtro para indicar ao componente de busca em quais classes a busca por documentos similares deve ser efetuada. A Tabela 10 exibe o ranking de classes para cada documento pesquisado, cuja primeira classe à esquerda é considerada a mais relevante e a última à direita é menos relevante. Os códigos destacados em negrito são as classes apontadas pelo classificador que correspondem às classes originais de cada documento. Observa-se que para os Documentos \#1 e \#2 as classes mais relevantes correspondem à classificação original das patentes. Para os Documentos \#4 e \#5 o classificador apontou as classes originais como a segunda mais relevante. Já para o Documento \#3 a classe original foi apontada pelo filtro como a de menor relevância das cinco primeiras posições do ranking realizado.

\begin{tabular}{ll}
\hline Busca & Ranking de Classes \\
\hline Documento \#1 & {$[\mathbf{7 0 2} / \mathbf{1 9}, 703 / 12,703 / 11,702 / 21,702 / 20]$} \\
Documento \#2 & {$[\mathbf{7 0 2} / \mathbf{2 0}, 702 / 19,703 / 12,703 / 11,702 / 21]$} \\
Documento \#3 & {$[702 / 20,703 / 12,702 / 19,703 / 11,702 / \mathbf{2 1}]$} \\
Documento \#4 & {$[703 / 12, \mathbf{7 0 3} / \mathbf{1 1}, 702 / 21,702 / 19,702 / 20]$} \\
Documento \#5 & {$[702 / 19, \mathbf{7 0 3} / \mathbf{1 2}, 703 / 11,702 / 21,702 / 20]$} \\
\hline
\end{tabular}


Tabela 10: Ranking de classes gerado pelo filtro para cada documento pesquisado.

A classificação do Documento \#3 não sugere a classe original nas duas primeiras posições. Um dos possíveis motivos é a limitada quantidade de exemplos de classificação da categoria 702/21. Segundo apresentado na Seção 6.1, a classe 702/21 apresenta 144 exemplos, enquanto a classe 703/12 possui 240 exemplos e as classes 702/19 e 702/20 possuem acima de 690 exemplos. Como o sistema seleciona as duas classes mais relevantes apontadas pelo filtro para efetuar as buscas, em termos de precisão, as classificações dos Documentos \#1, \#2, \#4 e \#5 podem ser consideradas satisfatórias, pois as classes originais estão entre as sugestões do classificador.

\subsubsection{Resultados das Buscas}

As Tabelas 11, 12, 13, 14 e 15 exibem os cinco primeiros resultados das buscas nas ferramentas PatFT (USPTO), Google Patents, Patentscope e Derwent (DII). A coluna BPS apresenta os resultados de busca do sistema BPS sem artefatos linguísticos, já a coluna BPS-GO exibe os resultados do sistema BPS com a utilização da Gene Ontology. Devido ao limite de espaço, as tabelas apresentam apenas os números de cada patente e o código de classificação USPC, caso a patente esteja classificada entre as categorias de Bioinformática do USPTO. No Apêndice D, o título, resumo e classes USPC podem ser consultados.

Na busca pelo Documento \#1 (US6882939), o qual pertence à classificação 702/19, apenas o sistema BPS apresentou a referida patente como a mais relevante (ver Tabela 11). As outras ferramentas não apresentaram o Documento \#1 entre as cinco mais relevantes. Ao analisar as classes de cada documento, observa-se que a ferramenta PatFT retornou dois documentos da mesma classe que a patente utilizada na pesquisa, sendo os documentos US8296300 e US8296116. Entre as variações do sistema BPS, ambas apresentaram apenas a patente US5557535 como documento não classificado em 702/19. No entanto, a variação BPS-GO atribuiu menor relevância a patente US5557535 que o BPS.

\begin{tabular}{|l|l|l|l|l|l|l|}
\hline Rank & PatFT & GooglePatents & Patentscope & Derwent & BPS & BPS-GO \\
\hline $1^{\circ}$ & US8296300 & US8263375 & US20020098517 & US2012143580 & $\begin{array}{l}\text { US6882939 } \\
{[702 / 19]}\end{array}$ & $\begin{array}{l}\text { US6882939 } \\
{[702 / 19]}\end{array}$ \\
& {$[702 / 19]$} & & & {$[9]$} \\
\hline
\end{tabular}




\begin{tabular}{|l|l|l|l|l|l|l|}
\hline Rank & PatFT & GooglePatents & Patentscope & Derwent & BPS & BPS-GO \\
\hline $2^{\circ}$ & $\begin{array}{l}\text { US8296116 } \\
{[702 / 19,} \\
703 / 11]\end{array}$ & $\begin{array}{l}\text { US8296300 } \\
{[702 / 19]}\end{array}$ & US20030088364 & US2012123760 & $\begin{array}{l}\text { US5557535 } \\
{[703 / 11,} \\
703 / 12]\end{array}$ & $\begin{array}{l}\text { US6629040 } \\
{[702 / 19]}\end{array}$ \\
\hline $3^{\circ}$ & $\begin{array}{l}\text { US8296108 } \\
{[703 / 11]}\end{array}$ & $\begin{array}{l}\text { US8280643 } \\
{[702 / 19]}\end{array}$ & US7751987 & US2012109535 & $\begin{array}{l}\text { US7462818 } \\
{[702 / 19]}\end{array}$ & $\begin{array}{l}\text { US8032347 } \\
{[702 / 19]}\end{array}$ \\
\hline $4^{\circ}$ & $\begin{array}{l}\text { US8296107 } \\
{[703 / 12]}\end{array}$ & $\begin{array}{l}\text { US8260596 } \\
{[703 / 11]}\end{array}$ & US20080215301 & US2012264115 & $\begin{array}{l}\text { US7855356 } \\
{[702 / 19]}\end{array}$ & $\begin{array}{l}\text { US7462818 } \\
{[702 / 19]}\end{array}$ \\
\hline $5^{\circ}$ & $\begin{array}{l}\text { US8296076 } \\
{[702 / 20]}\end{array}$ & $\begin{array}{l}\text { US8285490 } \\
{[702 / 19]}\end{array}$ & US20060069515 & US2012095694 & $\begin{array}{l}\text { US8278055 } \\
{[702 / 19]}\end{array}$ & $\begin{array}{l}\text { US5557535 } \\
{[703 / 11,} \\
703 / 12]\end{array}$ \\
\hline
\end{tabular}

Tabela 11: Números das patentes resultantes das buscas com o Documento \#1 US6882939 (702/19) - Rapid determination of protein global folds.

Na busca pelo Documento \#2 (US8296075), que pertence à classe USPC 702/20, as ferramentas PatFT, Patentscope e BPS retornaram o referido documento entre os cinco mais relevantes (ver Tabela 12). A ferramenta PatFT apresentou o Documento \#2 na quarta posição, o sistema Patentscope e o BPS, em suas duas variações, apresentaram o mesmo documento como o mais relevante. Ao analisar as classes de cada documento obtido pelo sistema BPS, observa-se que as variações do sistema BPS retornaram, cada uma, três documentos pertencentes à mesma classificação do documento buscado 702/20. No entanto, o BPS-GO atribuiu menor relevância ao documento US6512981, o qual não possui a classificação 702/20.

\begin{tabular}{|c|c|c|c|c|c|c|}
\hline Rank & PatFT & GooglePatents & Patentscope & Derwent & BPS & BPS-GO \\
\hline $1^{\circ}$ & $\begin{array}{l}\text { US8296108 } \\
{[703 / 11]}\end{array}$ & $\begin{array}{l}\text { US } 8280711 \\
{[702 / 20,} \\
703 / 11]\end{array}$ & US08296075 & US2012259556 & $\begin{array}{l}\text { US8296075 } \\
\text { [702/20] }\end{array}$ & $\begin{array}{l}\text { US8296075 } \\
\text { [702/20] }\end{array}$ \\
\hline $2^{\circ}$ & $\begin{array}{l}\text { US8296107 } \\
\text { [703/12] }\end{array}$ & $\begin{array}{l}\text { US8249814 } \\
{[702 / 19,} \\
703 / 11]\end{array}$ & US20050266411 & US2012253689 & $\begin{array}{l}\text { US7680606 } \\
\text { [702/19] }\end{array}$ & $\begin{array}{l}\text { US7680606 } \\
\text { [702/19] }\end{array}$ \\
\hline $3^{\circ}$ & $\begin{array}{l}\text { US8296076 } \\
\text { [702/20] }\end{array}$ & $\begin{array}{l}\text { US8271203 } \\
{[702 / 19,} \\
703 / 11]\end{array}$ & US20100145626 & US2012232862 & $\begin{array}{l}\text { US6988039 } \\
{[702 / 19,} \\
702 / 20]\end{array}$ & $\begin{array}{l}\text { US6988039 } \\
{[702 / 19,} \\
702 / 20]\end{array}$ \\
\hline $4^{\circ}$ & $\begin{array}{l}\text { US8296075 } \\
\text { [702/20] }\end{array}$ & $\begin{array}{l}\text { US8296108 } \\
{[703 / 11]}\end{array}$ & US20090182511 & US8225407 & $\begin{array}{l}\text { US6512981 } \\
\text { [702/19] }\end{array}$ & $\begin{array}{l}\text { US8086410 } \\
{[702 / 19,} \\
702 / 20]\end{array}$ \\
\hline $5^{\circ}$ & $\begin{array}{l}\text { US8296074 } \\
{[702 / 19]}\end{array}$ & $\begin{array}{l}\text { US8296107 } \\
{[703 / 12]}\end{array}$ & US20110246084 & US2012143580 & $\begin{array}{l}\text { US8086410 } \\
{[702 / 19,702 / 20]}\end{array}$ & $\begin{array}{l}\text { US6512981 } \\
\text { [702/19] }\end{array}$ \\
\hline
\end{tabular}

Tabela 12: Números das patentes resultantes das buscas com o Documento \#2 US8296075 (702/20) - Computer system and computer-facilitated method for nucleic acid sequence alignment and analysis. 
Na busca pelo Documento \#3 (US4063309), o qual pertence à classe 702/21, nenhuma ferramenta experimentada apresentou o Documento \#3 entre os cinco mais relevantes (ver Tabela 13). Especificamente no sistema BPS, o filtro sugeriu como mais relevantes as classes 702/20 e 703/12, ou seja, classes diferentes da classificação original do Documento \#3. Por isso, o sistema BPS não retornou a referida patente entre os cinco mais relevantes. No entanto, ambas variações do sistema BPS retornaram o documento US5526258 como o segundo mais relevante, o qual possui a mesma classificação do documento buscado 702/21. Isso se deve ao fato da patente US5526258 também estar classificada como 702/20, conforme Tabela 10.

\begin{tabular}{|c|c|c|c|c|c|c|}
\hline Rank & PatFT & GooglePatents & Patentscope & Derwent & BPS & BPS-GO \\
\hline $1^{\circ}$ & $\begin{array}{l}\text { US8296107 } \\
{[703 / 12]}\end{array}$ & $\begin{array}{l}\text { US8287739 } \\
{[702 / 19]}\end{array}$ & US20110178716 & US8225407 & $\begin{array}{l}\text { US7917306 } \\
{[702 / 20]}\end{array}$ & $\begin{array}{l}\text { US7917306 } \\
{[702 / 20]}\end{array}$ \\
\hline $2^{\circ}$ & $\begin{array}{l}\text { US8296076 } \\
{[702 / 20]}\end{array}$ & $\begin{array}{l}\text { US8271204 } \\
{[702 / 19]}\end{array}$ & US20120150479 & US8200389 & $\begin{array}{l}\text { US5526258 } \\
\text { [702/20, } \\
702 / 21]\end{array}$ & $\begin{array}{l}\text { US5526258 } \\
\text { [702/20, } \\
702 / 21]\end{array}$ \\
\hline $3^{\circ}$ & $\begin{array}{l}\text { US } 8296072 \\
{[702 / 19,} \\
702 / 20, \\
703 / 11]\end{array}$ & $\begin{array}{l}\text { US8289323 } \\
{[703 / 11]}\end{array}$ & US20110251813 & US2012123691 & $\begin{array}{l}\text { US5546323 } \\
{[702 / 20]}\end{array}$ & $\begin{array}{l}\text { US7047136 } \\
{[702 / 19,} \\
702 / 20]\end{array}$ \\
\hline $4^{\circ}$ & $\begin{array}{l}\text { US8296071 } \\
{[702 / 19]}\end{array}$ & $\begin{array}{l}\text { US8271250 } \\
{[703 / 11]}\end{array}$ & US8538718 & US2012109535 & $\begin{array}{l}\text { US8296076 } \\
{[702 / 20]}\end{array}$ & $\begin{array}{l}\text { US8117020 } \\
{[702 / 19,} \\
703 / 11, \\
703 / 12]\end{array}$ \\
\hline $5^{\circ}$ & $\begin{array}{l}\text { US8289323 } \\
{[703 / 11]}\end{array}$ & $\begin{array}{l}\text { US8265877 } \\
{[702 / 19]}\end{array}$ & US20120232803 & US2012264115 & $\begin{array}{l}\text { US8265880 } \\
{[702 / 20]}\end{array}$ & $\begin{array}{l}\text { US5546323 } \\
{[702 / 20]}\end{array}$ \\
\hline
\end{tabular}

Tabela 13: Números das patentes resultantes das buscas com o Documento \#3 US4063309 (702/21) - Mean corpuscular volume measuring apparatus and method.

Na iteração que efetuou buscas pelo Documento \#4 (US8271250), o qual pertence à classe 703/11, apenas os sistemas Google Patents e BPS retornaram o Documento \#4 entre os cinco mais relevantes (ver Tabela 14). Enquanto o Google Patents apresentou a patente na terceira posição, o sistema BPS, em suas duas variações, apontou o Documento \#4 como o mais relevante. Na análise das classes das patentes, observa-se que a ferramenta PatFT retornou duas patentes da classe 703/11 (US8296116 e US8296108). O Google Patents retornou três documentos pertencentes à classe 703/11 (US8249814, US8271250 e US8289323). Já as variações BPS e BPS-GO obtiveram, cada uma, quatro patentes da classe 703/11. Ambas as variações retornaram apenas a patente US6125332 com uma classificação diferente do Documento \#4, mas o BPS-GO novamente atribuiu menor relevância à esse documento, se comparado ao ranking do BPS. 


\begin{tabular}{|c|c|c|c|c|c|c|}
\hline Rank & PatFT & GooglePatents & Patentscope & Derwent & BPS & BPS-GO \\
\hline $1^{\circ}$ & $\begin{array}{l}\text { US8296300 } \\
\text { [702/19] }\end{array}$ & $\begin{array}{l}\text { US8249814 } \\
{[702 / 19,} \\
702 / 20,703 / 11]\end{array}$ & US7386400 & US2012143580 & $\begin{array}{l}\text { US8271250 } \\
{[703 / 11]}\end{array}$ & $\begin{array}{l}\text { US8271250 } \\
{[703 / 11]}\end{array}$ \\
\hline $2^{\circ}$ & $\begin{array}{l}\text { US8296116 } \\
{[703 / 11]}\end{array}$ & $\begin{array}{l}\text { US8296070 } \\
{[702 / 19,} \\
702 / 20]\end{array}$ & US8126656 & US8200389 & $\begin{array}{l}\text { US7386429 } \\
{[703 / 11]}\end{array}$ & $\begin{array}{l}\text { US7386429 } \\
{[703 / 11]}\end{array}$ \\
\hline $3^{\circ}$ & $\begin{array}{l}\text { US8296108 } \\
{[703 / 11]}\end{array}$ & $\begin{array}{l}\text { US8271250 } \\
{[703 / 11]}\end{array}$ & US20070016375 & US2012123691 & $\begin{array}{l}\text { US6125332 } \\
{[703 / 12]}\end{array}$ & $\begin{array}{l}\text { US7991560 } \\
{[702 / 19,} \\
702 / 20, \\
703 / 11]\end{array}$ \\
\hline $4^{\circ}$ & $\begin{array}{l}\text { US8296107 } \\
\text { [703/12] }\end{array}$ & $\begin{array}{l}\text { US8271204 } \\
{[702 / 19]}\end{array}$ & US20100191517 & US2012123760 & $\begin{array}{l}\text { US6671628 } \\
{[703 / 11]}\end{array}$ & $\begin{array}{l}\text { US6125332 } \\
\text { [702/32, } \\
703 / 12]\end{array}$ \\
\hline $5^{\circ}$ & $\begin{array}{l}\text { US8296076 } \\
{[702 / 20]}\end{array}$ & $\begin{array}{l}\text { US8289323 } \\
{[703 / 11]}\end{array}$ & US20020072863 & US2012264115 & $\begin{array}{l}\text { US8078432 } \\
{[703 / 11]}\end{array}$ & $\begin{array}{l}\text { US7383134 } \\
{[702 / 19,} \\
703 / 11]\end{array}$ \\
\hline
\end{tabular}

Tabela 14: Números das patentes resultantes das buscas com o Documento \#4 US8271250 (703/11) - Molecule design support apparatus and computer-readable.

Por fim, na quinta iteração com o Documento \#5 (US8271251), o qual pertence à classe 703/12 (ver Tabela 15), novamente os sistemas Google Patents e BPS apresentaram o Documento \#5 entre os cinco mais relevantes. O Google Patents posicionou o Documento \#5 como o quarto mais relevante e o sistema BPS, em suas duas variações, apresentou o Documento \#5 como o mais relevante. Ao analisar as classes das patentes obtidas nesta iteração, observa-se que apenas o Google Patents apresentou outras patentes da classe 703/12 (US8296107, US8275595 e US8271251).

\begin{tabular}{|l|l|l|l|l|l|l|}
\hline Rank & PatFT & GooglePatents & Patentscope & Derwent & BPS & BPS-GO \\
\hline $1^{\circ}$ & US8296300 & $\begin{array}{l}\text { US8249814 } \\
{[702 / 19,} \\
702 / 20,703 / 11]\end{array}$ & US20060212227 & US2012259556 & $\begin{array}{l}\text { US8271251 } \\
{[703 / 12]}\end{array}$ & $\begin{array}{l}\text { US8271251 } \\
\text { [703/12] }\end{array}$ \\
\hline $2^{\circ}$ & $\begin{array}{l}\text { US8296076 } \\
{[702 / 20]}\end{array}$ & $\begin{array}{l}\text { US8296107 } \\
{[703 / 12]}\end{array}$ & US20030167131 & US2012232862 & $\begin{array}{l}\text { US7877213 } \\
{[702 / 19]}\end{array}$ & $\begin{array}{l}\text { US7877213 } \\
{[702 / 19]}\end{array}$ \\
\hline $3^{\circ}$ & US8296075 & US8275595 & US20120310584 & US8225407 & $\begin{array}{l}\text { US8045782 } \\
{[702 / 19,}\end{array}$ & $\begin{array}{l}\text { US8045782 } \\
{[702 / 19,} \\
\end{array}$ \\
& {$[702 / 20]$} & {$[703 / 11$,} & & & $702 / 21]$ & $702 / 21]$ \\
\hline $4^{\circ}$ & US8296074 & US8271251 & US20060100787 & US2012143580 & US7818130 & US8271427 \\
& {$[702 / 19]$} & {$[703 / 12]$} & & & {$[702 / 19]$} & {$[702 / 19]$} \\
\hline $5^{\circ}$ & US8296071 & US8301391 & US20120253687 & US2012123691 & $\begin{array}{l}\text { US8271427 } \\
{[702 / 19]}\end{array}$ & $\begin{array}{l}\text { US7818130 } \\
{[702 / 19]}\end{array}$ \\
\hline
\end{tabular}

Tabela 15: Números das patentes resultantes das buscas com o Documento \#5 US8271251 (703/12) - Automated imaging system for single molecules). 
Como os termos de cada busca correspondem aos termos originais de cinco patentes de Bioinformática da coleção americana, era esperado que em cada busca, pelo menos o documento consultado fosse encontrado. Por exemplo, na busca pelo Documento \#1, o mesmo deveria estar, no mínimo, entre as cinco patentes mais relevantes retornadas pela ferramenta. Essa característica denota a precisão da ferramenta BPS em relação à busca lexical de documentos similares. Como pode ser verificado na Tabela 16, observou-se uma variação na precisão das ferramentas PatFT, Google Patents e BPS. Os valores de precisão da tabela foram obtidos conforme o seguinte cálculo: quantidade de vezes que o documento consultado foi encontrado como documento retornado $(d n)$ dividida pela quantidade de experimentos nos quais o mesmo deveria ser retornado pela ferramenta $N$. Por exemplo, o sistema PatFT do USPTO obteve o mesmo documento consultado apenas na busca pelo Documento $\# 2$, portanto a Precisão $=(1 \div 5)=20 \%$. Outros valores observados foram: Google Patents retornou o documento consultado em duas consultas e cada variação do sistema BPS obteve o documento consultado em quatro consultas. As ferramentas com melhor desempenho foram o Google Patents com $40 \%$ de precisão e o BPS e BPS-GO com $80 \%$ de precisão.

Outro aspecto analisado foram as classes dos documentos retornados por cada ferramenta. A Tabela 17 ilustra essa comparação. Considerando que cada consulta foi efetuada com um documento de cada classe americana de Bioinformática, espera-se que em cada consulta sejam retornados o maior número possível de documentos da mesma classe do documento consultado. Por exemplo, em uma consulta pelo Documento \#1 da classe 702/19, espera-se que ao menos a maioria dos cinco documentos retornados sejam da classe 702/19. Essa abordagem utiliza a informação de classificação das patentes para se obter mais documentos similares.

Nesse caso a precisão da ferramenta é dada pela quantidade de documentos retornados pelo sistema que pertencem à mesma classe do documento consultado dividida pelo total

\begin{tabular}{ccccc}
\hline Doc\# & PatFT & GooglePatents & BPS & BPS-GO \\
\hline 1 & - & - & 1 & 1 \\
2 & 1 & - & 1 & 1 \\
3 & - & - & - & - \\
4 & - & 1 & 1 & 1 \\
5 & - & 1 & 1 & 1 \\
\hline Total & 1 & 2 & 4 & 4 \\
\hline Precisão & $20 \%$ & $40 \%$ & $\mathbf{8 0 \%}$ & $\mathbf{8 0 \%}$ \\
\hline
\end{tabular}

Tabela 16: Precisão de busca de documentos das ferramentas utilizadas nos experimentos de Recuperação de Informação. 
de documentos a serem analisados em cada consulta. Por exemplo, na busca realizada na ferramenta PatFT pelo Documento \#1, que pertence à classe $702 / 19$, entre as cinco patentes retornadas pelo sistema, duas pertencem à classe 702/19. Na busca pelo Documento \#2, que pertence à classe 702/20, o PatFT também retornou duas patentes da classe 702/20 e na busca pelo Documento \#4, que pertence à classe 703/11, o PatFT também retornou duas patentes da classe 703/11. Assim, entre os 25 documentos retornados em todas as cinco consultas, seis patentes pertenciam às mesmas classes dos documentos consultados. Dessa maneira, tem-se a Precisão $=(6 \div 25)=24 \%$. Analisando a Tabela 17, observa-se que o BPS e o BPS-GO obtiveram a maior precisão entre as ferramentas analisadas, com $52 \%$.

As variações do sistema BPS que utilizaram termos normais na busca (BPS) e termos da Gene Ontology (BPS-GO) apresentaram desempenhos equivalentes em termos de precisão de documentos e classes. Contudo, analisando as patentes retornadas em cada consulta, verificam-se alguns documentos diferentes obtidos por BPS e BPS-GO. Para uma melhor avaliação desses documentos, seria necessário a análise direta dos resultados por um especialista de domínio ou uma coleção de referência que identificasse quais apontamentos são mais relevantes.

Buscou-se alternativas para avaliar e comparar o desempenho das duas variações do sistema BPS. Assim, optou-se por analisar a relevância atribuída aos documentos que não apresentam classificação igual à do documento consultado. A Tabela 18 ilustra essa análise.

De acordo com (JANSEN; SPINK, 2006), usuários de ferramentas de busca acessam de dois a três resultados em média, para cada consulta que executam. Isso pode indicar que quanto menor a posição numérica do documento no ranking de relevância, maior é a possibilidade do usuário acessá-lo. Considerando que patentes retornadas por sistemas de

\begin{tabular}{cccccc}
\hline Doc\# & Classe & PatFT & GooglePatents & BPS & BPS-GO \\
\hline 1 & $702 / 19$ & 2 & 4 & 4 & 4 \\
2 & $702 / 20$ & 2 & 1 & 3 & 3 \\
3 & $702 / 21$ & - & - & 1 & 1 \\
4 & $702 / 11$ & 2 & 3 & 4 & 4 \\
5 & $702 / 12$ & - & 3 & 1 & 1 \\
\hline & Total & 8 & 11 & 13 & 13 \\
\hline & Precisão & $24 \%$ & $44 \%$ & $\mathbf{5 2 \%}$ & $\mathbf{5 2 \%}$ \\
\hline
\end{tabular}

Tabela 17: Quantidade total e precisão de documentos retornados pelas buscas que possuem a mesma classificação do documento consultado. 


\begin{tabular}{llcc}
\hline Doc Consultado & Doc Obtido & Rank BPS & Rank BPS-GO \\
\hline$\# 1[702 / 19]$ & US5557535 [703/11,703/12] & $2 .^{\circ}$ & $\mathbf{5 .}^{\mathbf{o}}$ \\
$\# 2[702 / 20]$ & US7680606 [702/19] & $2 .^{\circ}$ & $2 .^{\circ}$ \\
$\# 2[702 / 20]$ & US6512981 [702/19] & $4 .^{\circ}$ & $\mathbf{5 .}^{\mathbf{o}}$ \\
$\# 3[702 / 21]^{*}$ & - & - & - \\
$\# 4[702 / 11]$ & US6125332 [703/12] & $3 .^{\circ}$ & $\mathbf{4 .}^{\mathbf{o}}$ \\
$\# 5[702 / 12]^{*}$ & - & - & - \\
\hline
\end{tabular}

*Experimentos que obtiveram a mesma quantidade de patentes com classificação diferente do documento consultado para ambas as variações

Tabela 18: Comparativo de relevância dos documentos retornados pelas consultas que apresentam classificação diferente do documento consultado para BPS e BPS-GO.

busca que não possuem a mesma classificação do documento consultado são menos relevantes, pode-se afirmar que o sistema BPS-GO que atribui menor relevância para patentes que não possuem a mesma classificação do documento consultado são mais eficientes.

Como se observa na Tabela 18, na consulta do Documento \#1, cuja classe é 702/19, foi retornada a patente US5557535 que não está classificada em 702/19. A abordagem BPS indicou que esse documento é o segundo mais relevante entre os cinco retornados. Já a abordagem BPS-GO considerou o documento US5557535 como o de menor relevância. Na consulta do Documento \#2 foram obtidas duas patentes que não estavam classificadas como 702/20, sendo 7680606 e 6512981, ambas classificadas como 702/19. A patente US7680606 esteve na mesma posição do ranking do BPS e BPS-GO. Já a patente US6512981 foi identificada como menos relevante pelo BPS-GO em comparação com o resultado do BPS. Por fim, na consulta do Documento \#4, a patente US6125332 também obteve menor relevância no BPS-GO do que no BPS. Das quatro patentes analisadas, a abordagem BPS-GO atribuiu menor relevância para três. Isso pode indicar que a utilização da Gene Ontology na busca textual auxiliou o sistema BPS a atribuir maior relevância aos documentos retornados que apresentam a mesma classificação do documento consultado. Outra contribuição do uso de artefatos linguísticos é a redução da dimensionalidade de termos, tornando-os mais significados. Investigações aprofundadas nesta questão estão sendo realizadas. 


\section{Conclusão}

O presente trabalho buscou investigar a utilização de artefatos linguísticos, técnicas de Recuperação de Informação e técnicas de Classificação Textual para guiar a busca por patentes de Bioinformática. Obteve-se como produto o sistema BPS, o qual conta com um componente de processamento textual que utiliza a Gene Ontology como artefato linguístico, um componente de classificação automática que utiliza o algoritmo Rakel com NBM para atuar como filtro e um componente de recuperação de informação responsável por calcular a similaridade entre os termos da consulta e os documentos da coleção e retornar um ranking de patentes relacionadas à busca.

Para modelar o classificador empregado no sistema BPS como filtro, foi utilizado um processo de KDD adaptado que utilizou patentes de Bioinformática obtidas no site do USPTO como exemplos de classificação. Os algoritmos de classificação multirrótulo RAkEL e ML-kNN foram experimentados e avaliados com diferentes parametrizações em diferentes coleções. O algoritmo com parametrizações de melhor desempenho foi o RAkEL com Naive Bayes Multinomial, o qual foi incorporado ao sistema BPS como filtro.

O módulo auxiliar responsável pelo processamento textual dos componentes de Classificação Textual e Recuperação de Informação utilizou a Gene Ontology como artefato linguístico com o objetivo de melhorar o desempenho do sistema. Segundo (LUPU et al., 2011) a utilização de artefatos linguísticos na classificação automática e busca de patentes, em geral, melhoram o desempenho dos algoritmos.

Em relação ao esperado aprimoramento da classificação com o uso da Gene Ontology, os experimentos realizados não conseguiram identificar essa contribuição em termos semânticos. Essa característica pode ser em decorrência dos termos GO serem muito específicos e apresentarem muitos termos não significativos para título e resumo de patentes, ou seja, os termos indexados pela GO são pouco utilizados na redação do título e resumo de patentes. Para desenvolver o sistema BPS neste trabalho, optou-se por utilizar a coleção com termos originais. Entretanto, os termos da Gene Ontology e seu método de 
utilização serão revisados e melhor analisados em trabalhos futuros. Em relação à busca no processamento de similaridades entre consulta e documentos da coleção, observou-se que a Gene Ontology contribuiu na ordenação dos resultados. Em três de quatro casos, as patentes retornadas de classes diferentes da classe da patente buscada possuem maior distância dos primeiros lugares na ordenação. Segundo (JANSEN; SPINK, 2006), a melhoria na ordenação dos resultados, ou seja, a apresentação dos documentos mais relevantes nas primeiras posições do ranking de documentos recuperados é um requisito que agrega poder competitivo às ferramentas de buscas atuais.

Para avaliar as buscas do sistema desenvolvido, o presente trabalho efetuou análise comparativa entre os resultados do sistema BPS e os resultados das ferramentas de busca PatFT (USPTO), Patentscope (WIPO), Derwent Innovations Index (Thomson Reuters) e Google Patents, as quais indexam a coleção americana de patentes. Para uma análise mais justa, estabeleceram-se critérios de busca iguais para todas as ferramentas, como limitação máxima de 256 caracteres para o texto buscado e delimitação do campo de busca apenas às classes de Bioinformática. Durante a preparação do experimento, observou-se que as ferramentas Derwent e Patentscope não permitiam delimitar as buscas às classes de Bioinformática. Assim, apenas as ferramentas PatFT (USPTO) e Google Patents foram comparadas ao BPS em termos de precisão e as buscas no Derwent e no Patentscope foram delimitadas às classes de Bioinformática da taxonomia internacional IPC $^{1}$ e exibidas a título de demonstração do processo de busca nessas ferramentas.

O sistema BPS é uma ferramenta gratuita que possui como diferenciais o foco na área de Bioinformática e a busca guiada por informações de classificação. Essas características tornam o BPS uma alternativa para pequenas e médias empresas brasileiras de pesquisa que precisam fazer buscas por patentes de Bioinformática e não podem arcar com os altos custos de uma ferramenta comercial de busca de patentes. Da maneira como foi projetado, o BPS permite ser aplicado à outras áreas do conhecimento. Para isso, o classificador deve ser treinado novamente com uma nova coleção da área que se deseja aplicar o BPS e incorporar a utilização de outro artefato linguístico (ontologia, tesauro, dicionário, etc) também relativo à essa nova área de aplicação.

O sistema BPS utiliza a informação de classificação para melhorar as buscas especificamente na área de Bioinformática e não genericamente. Espera-se que o BPS seja utilizado como complemento em uma das etapas de investigação de anterioridade. Caso o usuário tenha intenção de solicitar uma patente de Bioinformática, ele poderia identificar

\footnotetext{
${ }^{1}$ http://web2. wipo.int/ipcpub/ \#refresh $=$ symbol\&notion $=$ scheme\&symbol $=$ G06F0019100000
} 
em qual classe sua patente se encaixa melhor e encontrar patentes relacionadas à sua na área de Bioinformática. Essa característica também permite que usuários com patentes de outras áreas possam encontrar patentes de Bioinformática relacionadas a sua.

Como trabalho futuro, pretende-se formar uma equipe, sistematizar o experimento, realizar, avaliar e sistematizar os resultados para criar uma coleção de referência. Coleções de referência são caras e trabalhosas para serem construídas e importantes para analisar os resultados das consultas e identificar os pontos de melhoria de um sistema de Recuperação de Informação (BAEZA-YATES; RIBEIRO-NETO, 1999).

Outro trabalho futuro é a revisão da aplicação da Gene Ontology como artefato linguístico na Classificação Textual. Abordagens a serem avaliadas futuramente são (i) rever a metodologia de aplicação e (ii) utilizar os ramos da GO para obter informações de relacionamento. Considera-se também a utilização de outras ontologias ou artefatos linguísticos como a GENIA Ontology ${ }^{2}$ citada na Seção 3.3 e outras ontologias da Open Biological and Biomedical Ontologies (OBO) para subdomínios específicos, como a Protein Ontology (PRO).

\footnotetext{
${ }^{2}$ http://www.nactem.ac.uk/genia
} 


\section{Referências}

ALVES, R. T.; DELGADO, M. R.; FREITAS, A. A. Multi-label hierarchical classification of protein functions with artificial immune systems. In: BAZZAN, A. L. C.; CRAVEN, M.; MARTINS, N. F. (Ed.). Advances in Bioinformatics and Computational Biology, Third Brazilian Symposium on Bioinformatics, BSB 2008. [S.1.]: Springer, 2008. v. 5167, p. 1-12. ISBN 978-3-540-85556-9.

ASHBURNER, M.; BALl, C. A.; BlAKE, J. A.; BOTSTEIN, D.; BUTLER, H.; CHERRY, J. M.; DAVIS, A. P.; DOLINSKI, K.; DWIGHT, S. S.; EPPIG, J. T.; HARRIS, M. A.; HILL, D. P.; ISSEL-TARVER, L.; KASARSKIS, A.; LEWIS, S.; MATESE, J. C.; RICHARDSON, J. E.; RINGWALD, M.; RUBIN, G. M.; SHERLOCK, G. Gene ontology: tool for the unification of biology. The Gene Ontology Consortium. Nature genetics, Nature Publishing Group, Department of Genetics, Stanford University School of Medicine, California, USA. cherry@stanford.edu, v. 25, n. 1, p. 25-29, Maio 2000. ISSN 1061-4036. Disponível em: <http://dx.doi.org/10.1038/75556>.

BAEZA-YATES, R.; RIBEIRO-NETO, B. Modern Information Retrieval. Addison Wesley, 1999. 544 p. Disponível em: <http://sunsite.dcc.uchile.cl/irbook/>.

BARBOSA, D. B. Uma Introdução à Propriedade Intelectual. 2. ed. Lumen Juris, 2003. Disponível em: <http://www.denisbarbosa.addr.com/arquivos/livros/umaintro2.pdf >.

BaXevanis, A.; OUElletTe, B. Bioinformatics: A Practical Guide to the Analysis of Genes and Proteins. [S.l.]: Wiley, 2004. (Methods of Biochemical Analysis). ISBN 9780471461012 .

BUTTE, A. J. Translational bioinformatics: coming of age. Jounal of the American Medical Informatics Association: JAMIA, v. 15, p. 709?14, 2008. ISSN 1067-5027. Disponível em: <http://www.ncbi.nlm.nih.gov/pubmed/18755990>.

COHEN, K. B.; HUNTER, L. E. Chapter 16: Text mining for translational bioinformatics. PLoS Comput Biol, Public Library of Science, v. 9, n. 4, p. e1003044, Abril 2013. Disponível em: <http://dx.doi.org/10.1371\%2Fjournal.pcbi.1003044>.

CORTES, C.; VAPNIK, V. Support-vector networks. Machine Learning, Springer Netherlands, v. 20, p. 273-297, 1995. ISSN 0885-6125. 10.1007/BF00994018. Disponível em: <http://dx.doi.org/10.1007/BF00994018>.

DOLABELlA, R. As Patentes e o Desenvolvimento Nacional. 2009. Acesso em: Julho de 2013. Disponível em: <http://www.jornaldaciencia.org.br/Detalhe.jsp?id=63608>.

EISINGER, D.; WACHTER, T.; BUNDSCHUS, M.; WIENEKE, U.; SCHROEDER, M. Analysis of MeSH and IPC as a Prerequisite for Guided Patent Search. 2012. Disponível em: <http://bio-ontologies.knowledgeblog.org/346>. 
EPO. European Patent Office. Janeiro 2011. European Patent Office. Acesso em: Julho de 2013. Disponível em: <www.epo.org $>$.

FAGERBERG, J.; MOWERY, D. C.; NELSON, R. R. The Oxford Handbook of Innovation. Oxford University Press, 2006. 680 p. Disponível em: <http://www.amazon.com/Oxford-Handbook-Innovation-Handbooks/dp/0199286809>.

FAPESP. Indicadores de Ciência, Tecnologia e Inovação em São Paulo 2010. [S.1.], 2010. Cap. 5: Atividade de patenteamento no Brasil e no exterior; Acesso em: Julho de 2013. Disponível em: <http://www.fapesp.br/indicadores/2010/volume1/cap5.pdf>.

FELDMAN, R.; SANGER, J. The Text Mining Handbook: Advanced Approaches in Analyzing Unstructured Data. Cambridge, MA, USA: Cambridge University Press, 2006. ISBN 0521836573.

GATTO, J. Bioinformatics patents challenges and opportunities. 2001. Disponível em: $<$ http://www.mintz.com/newspubs/IntelProp/Bioinfo-Adv11-01.pdf $>$.

GRAY, K. A.; DAUGHERTY, L.; GORDON, S. M.; SEAL, R. L.; WRIGHT, M. W.; BRUFORD, E. A. Genenames.org: the hgnc resources in 2013. Nucleic Acids Research, v. 41, n. Database-Issue, p. 545-552, 2013.

HULTQUIST, S.; HARRISON, R.; YANG, Y. Patenting bioinformatic inventions emerging trends in the united states. Nature Biotechnology, v. 20, n. 7, p. 743-4, 2002.

INOVAçãO, A. U. de. Patentes. 2011. USP INOVAÇÃO. Acesso em: Julho de 2013. Disponível em: <http://www.inovacao.usp.br/propriedade/patentes.php $>$.

INPI. Guia de Depósito de Patentes. 2008. Acesso em: Julho de 2013. Disponível em: $<$ http://www.inpi.gov.br/portal/artigo/guia_basico_patentes $>$.

INPI. Relatório de Gestão 2009. [S.1.], 2009. Cap. 5: Diretoria de Patentes; Acesso em: Julho de 2013. Disponível em: $<$ http://www.fapesp.br/indicadores/2010/volume1/cap5.pdf $>$.

INPI. Boletim Estatistico de Patentes 2010. [S.1.], 2010. Acesso em: Julho de 2013. Disponível em: <http://www.inpi.gov.br $>$.

INPI. Pedidos de Patentes e Desenhos Industriais até 2010. [S.1.], 2010. Acesso em: Julho de 2013. Disponível em: <http://www.inpi.gov.br/menusuperior/imprensa/informacoesparaimprensa/estatisticas/pedidos-de-patentes-edesenhos-industriais-2006-a-2010>.

INPI. Instituto Nacional de Propriedade Industrial. Agosto 2011. Combate ao backlog de patentes é prioridade no INPI. Acesso em: Julho de 2013. Disponível em: $<$ http://www.inpi.gov.br/noticias/combate-ao-backlog-de-patentes-e-prioridade-noinpi $>$.

INPI. Instituto Nacional de Propriedade Industrial. Janeiro 2011. Instituto Nacional de Propriedade Industrial. Acesso em: Julho de 2013. Disponível em: <www.inpi.gov.br >. 
INPI. Patentes também podem contar História do Brasil. 2011. Acesso em: Julho de 2013. Disponível em: <http://www.inpi.gov.br/noticias/patentes-tambem-podemcontar-historia-do-brasil $>$.

INPI. Busca de Patentes Online. 2012. Acesso em: Julho de 2013. Disponível em: $<$ http://www.inpi.gov.br/portal/artigo/busca_de_patentes_online $>$.

JACKSON, P.; MOULINIER, I. Natural Language Processing for Online Applications: Text Retrieval, Extraction and Categorization. Amsterdam: John Benjamins, 2002.

JANSEN, B. J.; SPINK, A. How are we searching the world wide web?: a comparison of nine search engine transaction logs. Information Processing and Management: an International Journal, Pergamon Press, Inc., Tarrytown, NY, USA, v. 42, n. 1, p. 248-263, jan 2006. ISSN 0306-4573. Disponível em: $<$ http://dx.doi.org/10.1016/j.ipm.2004.10.007>.

JOACHIMS, T. Text categorization with suport vector machines: Learning with many relevant features. In: Proceedings of the 10th European Conference on Machine Learning. London, UK, UK: Springer-Verlag, 1998. (ECML '98), p. 137-142. ISBN 3-540-64417-2. Disponível em: <http://dl.acm.org/citation.cfm?id=645326.649721>.

KIM, J.-D.; OHTA, T.; TATEISI, Y.; TSUJII, J. ichi. GENIA corpus - a semantically annotated corpus for bio-textmining. p. 180-182, 2003. Disponível em: $<$ http://bioinformatics.oupjournals.org/cgi/content/abstract/19/suppl_1/i180?etoc $>$.

LESK, A. Introduction to Bioinformatics. [S.1.]: Oxford University Press, 2002. ISBN 9780199251964 .

LUPU, M.; MAYER, K.; TAIT, J.; TRIPPE, A. J. Current Challenges in Patent Information Retrieval. Springer, 2011. 417 p. Disponível em: $<$ http://www.springerlink.com/content/978-3-642-19231-9\#section=878399\&page $=1>$.

MANNING, C. D.; RAGHAVAN, P.; SCHüTZE, H. Introduction to Information Retrieval. New York, NY, USA: Cambridge University Press, 2008. ISBN 0521865719, 9780521865715 .

MCCALLUM, A. K. Multi-label text classification with a mixture model trained by em. In: AAAI 99 Workshop on Text Learning. [S.l.: s.n.], 1999.

MONARD, M. C.; BARANAUSKAS, J. A. Sistemas inteligentes: Fundamentos e aplicações. In: __ [S.l.]: Manole, 2003. cap. Conceitos sobre Aprendizado de Máquina, p. $89-114$.

MOUNT, D. M. Bioinformatics - Sequence and Genome Analysis. 1. ed. [S.1.]: Cold Spring Harbor Laboratory Press, 2001.

MUKHERJEA, S.; BAMBA, B. Biopatentminer: an information retrieval system for biomedical patents. In: $V L D B$ '04 Proceedings of the Thirtieth international conference on Very large data bases. Very Large Data Bases (VLDB) Endowment, 2004. v. 30, p. 1066 - 1077. Disponível em: $<$ http:/ $/$ portal.acm.org/citation.cfm?id $=1316781 \& \mathrm{dl}=\mathrm{ACM} \&$ coll $=\mathrm{DL} \& \mathrm{CFID}=36664752 \&$ CFTOKEN $=92708978>$. 
PARK, H.-S. Preliminary study of bioinformatics patents and their classifications registered in the kipris database. Genomics \& Informatics, p. 271-274, 2012. Disponível em: <http://genominfo.org/DOIx.php?id=10.5808/GI.2012.10.4.271>.

RASMUSSEN, B. Commercialisation processes in bioinformatics: Analysis of bioinformatics patents. Centre for Strategic Economic Studies (CSES) - Victoria University - Australia, 2005. Disponível em: <www.cfses.com/documents/wp26.pdf>.

REID, P. Obama's Call For Innovation Stifled by Patent Office Backlog. Janeiro 2011. Acesso em: Julho de 2013. Disponível em: <http://www.cbsnews.com/8301503544_162-20029731-503544.html?tag=mncol;lst;1>.

RIBEIRO, L.; RUIZ, R.; BERNARDES, A.; ALBUQUERQUE, E. Matrices of science and technology interactions and patterns of structured growth: implications for development. Scientometrics, Akadémiai Kiadó, co-published with Springer Science+Business Media B.V., Formerly Kluwer Academic Publishers B.V., v. 83, p. 55-75, 2010. ISSN 0138-9130. 10.1007/s11192-009-0020-3. Disponível em: $<$ http://dx.doi.org/10.1007/s11192-009-0020-3>.

RICHARDS, J. Utility model protection throughout the world. 2010. Disponível em: <http://www.ipo.org/AM/Template.cfm?Template=/CM/ ContentDisplay.cfm\&ContentID $=25244>$.

RODRIGUEZ-ESTEBAN, R. Biomedical text mining and its applications. PLoS Comput Biol, Public Library of Science, v. 5, n. 12, p. e1000597, Dezembro 2009.

RODRIGUEZ, V. The backlog issue in patents: A look at the european case. World Patent Information, v. 32, n. 4, p. 287-290, 2010. Disponível em: <http://econpapers.repec.org/RePEc:eee:worpat:v:32:y:2010:i:4:p:287-290>.

SALTON, G.; WONG, A.; YANG, C. S. A vector space model for automatic indexing. Commun. ACM, ACM, New York, NY, USA, v. 18, p. 613-620, Novembro 1975. ISSN 0001-0782. Disponível em: <http://doi.acm.org/10.1145/361219.361220>.

SCHAPIRE, R. E.; SINGER, Y. Boostexter: A boosting-based system for text categorization. In: Machine Learning. [S.l.: s.n.], 2000. p. 135-168.

SHEN, X.; BOUTELL, M.; LUO, J.; BROWN, C. M. Multilabel machine learning and its application to semantic scene classification. In: YEUNG, M. M.; LIENHART, R.; LI, C.-S. (Ed.). Storage and Retrieval Methods and Applications for Multimedia. SPIE, 2004. (SPIE Proceedings, v. 5307), p. 188-199. Disponível em: <http://dblp.unitrier.de/db/conf/spieSR/spieSR2004.html\#ShenBLB04>.

SMITH, B.; ASHBURNER, M.; ROSSE, C.; BARD, J.; BUG, W.; CEUSTERS, W.; GOLDBERG, L. J.; EILBECK, K.; IRELAND, A.; MUNGALL, C. J.; OBI Consortium; LEONTIS, N.; ROCCA-SERRA, P.; RUTTENBERG, A.; SANSONE, S.-A. A.; SCHEUERMANN, R. H.; SHAH, N.; WHETZEL, P. L.; LEWIS, S. The obo foundry: coordinated evolution of ontologies to support biomedical data integration. Nature biotechnology, Nature Publishing Group, v. 25, n. 11, p. 1251-1255, Novembro 2007. ISSN 1087-0156. Disponível em: <http://dx.doi.org/10.1038/nbt1346>. 
TEIXEIRA, F.; SOUSA, F. S.; ARAUJO, G. D.; MANCINI, F.; ARAUJO, L. V.; PISA, I. T. Indexação de artigos científicos de informática em saúde por meio da competição de técnicas de extração de características. XII Workshop de Informática Médica (WIM 2012), 2012. ISSN 2175-2761.

THE GENE ONTOLOGY CONSORTIUM. An Introduction to the Gene Ontology. 2013. Acesso em: Julho de 2013. Disponível em: $<$ http://www.geneontology.org/GO.doc.shtml >.

THE GEnE ONTOLOGY CONSORTIUM. Ontology Relations. 2013. Acesso em: Julho de 2013. Disponível em: <http://www.geneontology.org/GO.ontology.relations.shtml>.

THE GENE ONTOLOGY CONSORTIUM. Ontology Structure. 2013. Acesso em: Julho de 2013. Disponível em: <http://www.geneontology.org/GO.ontology.structure.shtml>.

TSOUMAKAS, G.; KATAKIS, I.; VLAHAVAS, I. P. Mining multi-label data. In: Data Mining and Knowledge Discovery Handbook. [S.l.: s.n.], 2010. p. 667-685.

TSOUMAKAS, G.; KATAKIS, I.; VLAHAVAS, I. P. Random k-labelsets for multilabel classification. IEEE Transactions on Knowledge and Data Engineering, v. 23, n. 7, p. 1079-1089, 2011.

TSOUMAKAS, G.; SPYROMITROS-XIOUFIS, E.; VILCEK, J.; VLAHAVAS, I. Mulan: A java library for multi-label learning. Journal of Machine Learning Research, v. 12, p. 2411-2414, 2011.

USP. Agência USP de Inovação. Janeiro 2011. Acesso em: Julho de 2013. Disponível em: $<$ www.inovacao.usp.br $>$.

USPTO. Handbook of Classification. 2005. Acesso em: Julho de 2013. Disponível em: <http://www.uspto.gov/web/offices/opc/documents/handbook.pdf>.

USPTO. United States Trademark and Patent Office. Janeiro 2012. United States Trademark and Patent Office. Acesso em: Julho de 2013. Disponível em: $<$ www.uspto.gov $>$.

USPTO. Editorial Standards - Publications and Citations. Julho 2013. United States Trademark and Patent Office. Acesso em: Julho de 2013. Disponível em: $<$ http://www.uspto.gov/news/media/ccpubguide.jsp $>$.

USPTO. Manual of patent examining procedure. In: 2013. cap. 900 - Prior Art and Classification Search. sec. 904 - How to Search. Acesso em: Julho de 2013. Disponível em: <http://www.uspto.gov/web/offices/pac/mpep/s904.html>.

VAlliM, R. M. M. Sistemas Classificadores Evolutivos para Problemas Multirrótulo. Dissertação (Mestrado) - Instituto de Ciências Matemáticas e de Computação ICMC/USP, 2010.

WIPO. IPC Electronic Forum - Project A019 - Bioinformatics. 2010. Acesso em: Julho de 2013. Disponível em: <http://web2.wipo.int/ipc-ief/en/project/1314/A019>. 
WIPO. Patent Applications by Country of Origin and by Office (1995-2009). Setembro 2010. Statistical Publication. Acesso em: Julho de 2013. Disponível em: $<$ www.wipo.int/export/sites/www/ipstats/en/statistics/patents $>$.

WIPO. Patent Grants by Country of Origin and by Office (1995-2009). Setembro 2010. Statistical Publication. Acesso em: Julho de 2013. Disponível em: $<$ www.wipo.int/export/sites/www/ipstats/en/statistics/patents/xls $>$.

WIPO. WIPO Treaties - General Information. [S.l.], 2010. Acesso em: Julho de 2013. Disponível em: <http://www.wipo.int/treaties/en/general/>.

WIPO. World Intellectual Property Indicators 2010. [S.1.], 2010. Acesso em: Julho de 2013. Disponível em: <www.wipo.int>.

WITTEN, I. H.; FRANK, E.; HALL, M. A. Data Mining: Practical Machine Learning Tools and Techniques. 3. ed. Amsterdam: Morgan Kaufmann, 2011. ISBN 978-0-12-374856-0. Disponível em: $<$ http://www.sciencedirect.com/science/book/9780123748560>.

ZHANG, M. ling; ZHOU, Z. hua. Ml-knn: A lazy learning approach to multi-label learning. PATTERN RECOGNITION, v. 40, p. 2007, 2007. 


\section{APÊENICE A - Classes USPC de Bioinformática}

Neste apêndice são detalhadas as definições de cada classe e subclasse de Bioinformática da taxonomia americana US Patent Classification (USPC). A hierarquia das classes e subclasses é ilustrada de maneira resumida na Tabela 19. As descrições estão em inglês, a qual é a linguagem original do USPTO.

\begin{tabular}{|c|c|c|c|c|c|}
\hline \multirow{5}{*}{\multicolumn{2}{|c|}{702}} & & & & \multirow{2}{*}{$\begin{array}{c}\text { Bioinformatics } \\
\text { Classes }\end{array}$} \\
\hline & & \multicolumn{3}{|c|}{ Measurement System in a Specific Environment } & \\
\hline & & \multirow[t]{3}{*}{19} & Bio & gical or biochemical & $702 / 19$ \\
\hline & & & 20 & Gene sequence determination & $702 / 20$ \\
\hline & & & & Cell count or shape or size analysis & $702 / 21$ \\
\hline \multirow[t]{4}{*}{703} & \multicolumn{4}{|c|}{ Data Processing: Structural, Design, Modeling, Simulation and Emulation } & \\
\hline & \multirow[t]{3}{*}{6} & \multicolumn{3}{|c|}{ Simulating Nonelectrical Device or System } & \\
\hline & & 11 & Bio & gical or biochemical & 703/11 \\
\hline & & 12 & Che & ical & $703 / 12$ \\
\hline
\end{tabular}

Tabela 19: Classes USPC de Bioinformática e hierarquias (USPTO, 2012).

\section{CLASS 702 - DATA PROCESSING: MEASURING, CALIBRATING, OR TESTING \\ CLASS DEFINITION}

This class provides for apparatus and corresponding methods wherein the data processing system or calculating computer is designed for or utilized in an environment relating to a specific or generic measurement system, a calibration or correction system, or a testing system.

This class is structured into four main parts:

1. Data processing for a measurement system in a specific environment.

2. Data processing for a calibration or correction system.

3. Data processing for a testing system. 
4. Data processing for a generic measurement system.

See Subclass References to the Current Class for these specific subclasses.

Scope of the class:

\section{A. MEASUREMENT SYSTEM IN A SPECIFIC ENVIRONMENT}

This class is limited to data processing and calculating computer apparatus and corresponding methods for measuring in a specific environment. There must be significant claim recitation of the data processing system, process or calculating computer and nominal recitation of the specific environment. When significant structure of the device or process pertinent to the specific environment is claimed, classification is in the appropriate device or process class. Control system for specific application adapted for a sole purpose of measuring is classified in this class. This class does not includes data processing in combination with a specific application control system for controlling a device or apparatus (see References To Other Classes below for a generic or specific electrical computers and data processing control systems).

\section{B. CALIBRATION OR CORRECTION SYSTEM}

This class includes subject matter directed to data processing for calibration or correction system disclosed or claimed in plural art devices such as geometrical instrument, mechanical system, timing apparatus, fluid flow or fluid measurement, etc. (see References To Other Classes below).

\section{TESTING SYSTEM}

This class includes subject matter directed to data processing for testing system disclosed in plural art devices such as electrical circuit and components testing, sensing apparatus testing, signal converting, shaping or generating (see References To Other Classes below).

This outdent excludes a mere monitoring system for determining performance of a device or process under normal operation without subjecting the device or process to a specific testing procedure or signal.

\section{GENERIC MEASUREMENT SYSTEM}

This class is limited to data processing and calculating computer apparatus and corresponding methods for measuring that are not strictly adapted to one particular environment. Such apparatus and corresponding methods for measuring could extend to several different applications. There must be significant claim recitation of the data processing 
system, process or calculating computer. A generic control system adapted for a sole purpose of measuring is classified in this class. This class does not includes data processing in combination with a generic control system for controlling a device or apparatus (see References To Other Classes below for a generic or specific electrical computers and data processing control systems).

\section{SUBCLASSES}

\section{1 - MEASUREMENT SYSTEM IN A SPECIFIC ENVIRONMENT}

This subclass is indented under the 702 class definition. Subject matter wherein the data processing system or calculating computer includes a measurement system or process designed for or utilized in a particular art device or application.

\section{9 - Biological or biochemical}

This subclass is indented under subclass 1 . Subject matter wherein the data processing system or calculating computer is designed for or utilized in a measurement system directed to an environment of life or chemical compound or process in a living system.

\section{0 - Gene sequence determination}

This subclass is indented under subclass 19. Subject matter including a chemical process which determines genetic information including the chains of a set of sequencing fragments (e.g., DNA sequence information) used to define identity of biological species.

\section{1 - Cell count or shape or size analysis (e.g., blood cell)}

This subclass is indented under subclass 19. Subject matter comprising a measuring means for determining quantity, geometric, or proportional dimensions of a particular biological particle.

CLASS 703 - DATA PROCESSING: MEASURING, CALIBRATING, OR TESTING

\section{CLASS DEFINITION}

This class provides for electrical data processing apparatus and corresponding methods for the following subject matter:

A. Processes or apparatus for sketching or outlining of layout of a physical object or part.

B. Processes or apparatus for representing a physical process or system by mathemat- 
ical expression.

C. Processes or apparatus for modeling a physical system which includes devices for performing arithmetic and some limited logic operation upon an electrical signal, such as current or voltage, which is a continuously varying representation of physical quantity.

D. Processes or apparatus for modeling to reproduce a nonelectrical device or system to predict its performance or to obtain a desired performance.

E. Processes or apparatus for modeling and reproducing an electronic device or electrical system to predict its performance or to obtain a desired performance.

F. Processes or apparatus that allows the data processing system to interpret and execute programs written for another kind of data processing system.

\section{SCOPE OF THE CLASS}

(1) Note. This class is limited to electrical data processing apparatus and corresponding methods for structural design, modeling, simulation, and emulation. (2) Note. Claims directed to electrical digital logic circuitry or miscellaneous active electrical nonlinear devices and systems are classified elsewhere. See the SEE OR SEARCH CLASS notes below. (3) Note. Significantly claimed apparatus external to this class, claimed in combination with apparatus under the class definition, which perform structural design, modeling, simulation, or emulation data processing are classified in the class appropriate to the external device unless specifically excluded therefrom. (4) Note. Nominally claimed apparatus external to this class in combination with apparatus under the class definition is classified in this class unless provided for in the appropriate external class.

\section{SUBCLASSES}

\section{6 - SIMULATING NONELECTRICAL DEVICE OR SYSTEM}

This subclass is indented under the 703 class definition. Subject matter comprising means or steps for modeling (i.e., artificially mimicking) to reproduce a nonelectrical device or system to predict its performance or to obtain a desired performance. (1) Note. Examples of simulation of such nonelectrical device or system includes tire tread noise, fog effect, physical process, process time for manufacturing metal die, evaluating human performance, or colored fabric or textile.

\section{1 - Biological or biochemical}

This subclass is indented under subclass 6 . Subject matter wherein the simulated system is a biological or biochemical system. 


\section{2 - Chemical}

This subclass is indented under subclass 6 . Subject matter wherein the simulated system is a chemical system. 


\section{APÊEDICE B - Ferramentas de Busca Referenciadas na Seção 6.3}

Neste apêndice são descritas as ferramentas de busca de patentes utilizadas nos experimentos de busca descritos na Seção 6.3.

\section{Derwent Innovations Index (DII)}

O DII é um produto comercial da empresa Thomson Reuters ${ }^{1}$ disponibilizado para a Universidade de São Paulo (USP) pela Coordenação de Aperfeiçoamento de Pessoal de Nível Superior (CAPES) ${ }^{2}$. De acordo com o site da ferramenta, o DII possui 22 milhões de patentes de 40 escritórios de marcas e patentes. Cada patente indexada pelo DII tem seu título e resumo alterados por especialistas que redigem novos títulos e resumos mais descritivos do que os originais. Comumente os resumos são divididos em subtópicos como Inovação, Uso e Vantagem, para facilitar e agilizar a leitura e compreensão do conteúdo de cada patente. A ferramenta apresenta as classificações das patentes de acordo com o IPC e uma taxonomia própria $\mathrm{DWPI}^{3}$ e, mesmo para patentes americanas, não apresenta as classes USPC.

A ferramenta DII permite buscas textuais por tópico, que abrangem título, resumo, resumos equivalentes de patentes da mesma família, e palavras-chave (title-terms). Outras opções são busca por título, número de patente, inventor, concessionário, classificação IPC e DWPI. Essas opções podem ser combinadas utilizando-se operadores lógicos $A N D$ (intersecção), OR (união) e NOT (exclusão). Opcionalmente, estes mesmos operadores lógicos podem compor os termos de pesquisa nas opções de busca por tópico e título. A ferramenta também utiliza os conceitos de remoção de stopwords e redução dos termos ao seu radical (stemming). O DII não disponibiliza filtros por escritório de concessão e não ordena os resultados por grau de relevância. A ordenação é feita por data de inclusão

\footnotetext{
${ }^{1} \mathrm{http}: / /$ thomsonreuters.com

${ }^{2}$ http://www.capes.gov.br

${ }^{3} \mathrm{http}: / /$ ip-science.thomsonreuters.com/support/patents/dwpiref/reftools/classification
} 
no sistema, data de patente mais recente, inventor, concessionário (nome ou código), quantidade de citações e classificação DWPI.

\section{Patent Full-Text and Image Database - PatFT (USPTO)}

O PatFT é a ferramenta de busca gratuita que o escritório americano disponibiliza em seu site para pesquisas no banco de patentes do USPTO. Assim como outras ferramentas, o PatFT apresenta opções de busca rápida e avançada. A busca rápida possui interface mais amigável para compor os termos das pesquisas, enquanto a busca avançada permite compor consultas mais elaboradas. Em ambos os modos de pesquisa a ferramenta disponibiliza 44 campos diferentes para compor as buscas, entre eles estão número de patente, título, resumo, descrição, reivindicação, IPC, USPC, inventor, concessionário, entre outros. Os diversos campos podem ser associados utilizando-se os operadores lógicos $A N D$ (intersecção), OR (união) e ANDNOT (exclusão). Para buscas em campos de texto livre, como título, resumo, descrição e reivindicação os mesmos operadores lógicos podem ser associados aos termos da consulta.

Os termos das consultas são limitados à 256 caracteres e a ferramenta não indexa stopwords, ou seja, termos como artigos, preposições e pronomes são descartados da consulta automaticamente. Os resultados não apresentam grau de relevância e são exibidos em ordem decrescente por data de concessão. Os resultados são apresentados em uma lista simples com o número da patente, título e uma hiperligação para o documento. O PatFT exibe o conteúdo textual completo e original de cada patente em HTML, ou seja, diferentemente do DII os títulos e resumos não são incrementados com textos mais descritivos. A visualização das imagens das patentes também é possível, no entanto é necessário que seja instalado um plug-in no navegador específico para exibir imagens do tipo TIFF.

\section{Patentscope (WIPO)}

O Patentscope é a ferramenta gratuita de busca de patentes disponibilizada pelo escritório internacional (WIPO). O Patentscope cobre mais de 30 milhões de patentes, das quais 2,2 milhões foram depositadas de acordo com o PCT. A ferramenta disponibiliza 49 opções de campos de busca, dentre os quais estão busca por todos os campos, número de patente, título, resumo, descrição, reivindicação, IPC, inventor, concessionário, entre outros. Estes campos podem ser combinados com os operadores lógicos AND, OR, NOT e $A N D N O T$. O sistema possibilita filtrar os resultados por escritório de concessão.

O Patentscope disponibiliza quatro tipos de pesquisa, sendo simples, avançada, por combinação de campos e linguagens diferentes. Na busca simples, o usuário seleciona 
apenas um campo de pesquisa; na busca avançada, os termos da pesquisa podem ser compostos em um único texto com indicadores para cada campo. Essa opção permite compor consultas mais elaboradas. Na busca por combinação de campos é disponibilizada uma interface específica e mais intuitiva, a qual permite escolher os campos de interesse e os operadores lógicos em caixas de seleção. Por fim, a ferramenta permite expansão de buscas por 12 línguas diferentes utilizando tradutores, entre elas o Português. Nesse modo é possível selecionar sinônimos e definir o nível de precisão e revocação da consulta.

Para processar as consultas, o Patentscope utiliza as técnicas de remoção de stopwords e redução dos termos ao seu radical (stemming). Os resultados são exibidos ordenados por grau de relevância, data de publicação e depósito. As informações textuais e imagens originais do documento são exibidas por completo. No entanto, o sistema não exibe a classificação USPC para patentes americanas.

\section{Google Patent Search}

O Google Patent Search é a ferramenta de busca gratuita do Google especializada em documentos de patentes. O Google Patent Search apresenta layout próximo de sua ferramenta de busca na Internet, mas com opções de pesquisa específicas para patentes. As buscas nessa ferramenta cobrem as coleções completas do escritório americano (USPTO) e de escritório europeu (EPO).

O Google Patent Search disponibiliza três tipos de busca, simples, avançada e por anterioridade. O modo de busca simples apresenta a mesma interface da ferramenta de busca da empresa para a Internet, com um campo texto simples de no máximo 32 palavras. Podem ser pesquisados número de patentes ou termos presentes em quaisquer campos da patente. O modo avançado permite combinar 11 campos diferentes, entre eles palavras, número da patente, título, inventor, concessionário, classificação americana (USPC) e internacional (IPC).

Os resultados são exibidos em ordem decrescente por grau de relevância. Diferentemente da ferramenta DII, as patentes exibidas apresentam conteúdo original, sem adição de termos descritivos ao título e resumo. Também são exibidas as imagens das patentes e a ferramenta possibilita baixar o arquivo original da patente em formato PDF. 


\section{APÊEDICE C - Lista de Abreviaturas}

Neste apêndice são exibidas as abreviaturas referenciadas neste trabalho e seus respectivos significados.

BPS: Bioinformatics Patent Search

DII: Derwent Innovation Index

DWPI: Taxonomia DII

EPO: European Patent Office

GENOPROT: Rede Integrada de Estudos Genômicos e Proteômicos

GO: Gene Ontology

idf: Inverted Documento Frequency

INPI: Instituto Nacional de Propriedade Industrial

IPC: International Patent Classification

IR: Information Retrieval

ISI: Institute for Scientific Information

KDD: Knowledge Discovery in Databases

kNN: k Nearest Neighbours

LP: Label Powerset

LPI: Lei da Propriedade Industrial (lei 9.279 de 1996)

ML: Machine Learning 
ML-kNN: Multilabel k Nearest Neighbours

MU: Modelo de Utilidade

NBM: Naive Bayes Multinomial

OBO: Open Biological and Biomedical Ontologies

OST: Observatoire des Sciences et des Techniques

PatFT: Patent Full-Text and Image Database

PI: Patente de Invenção

Rakel: Random k-Label Sets

RENORBIO: Programa Rede Nordeste de Biotecnologia

SVM: Support Vector Machines

TC: Text Categorization

tf: Term Frequency

USPC: United States Patent Classification

USPTO: United States Patent and Trademark Office

WIPO: World Intellectual Property Organization 


\section{APÊENICE D - Patentes Referenciadas na Seção 6.3}

Neste apêndice são apresentadas as patentes retornadas pelas ferramentas de busca utilizadas nos experimentos descritos na Seção 6.3. Os campos exibidos são: número, título, resumo e classificação americana (USPC) e internacional (IPC). Para as patentes que apresentam a classificação internacional, a classificação americana é apresentada entre parênteses. As patentes estão em ordem crescente de número.

Número - Título: US5526258 - Method and apparatus for automated analysis of biological specimens

Classes: $382 / 129,356 / 39,382 / 133,702 / 20,702 / 21$

Resumo: An apparatus and method for analyzing the cell objects of a cell sample for the diagnosis and treatment of actual or suspected cancer is disclosed. An image of the cell sample is first digitized and morphological attributes, including area and DNA mass of the cell objects are automatically measured from the digitized image. The measured attributes are compared to ranges of attribute values which are preestablished to select particular cell objects having value in cancer analysis. After the selection of cell objects, the image is displayed to an operator and indicia of selection is displayed with each selected cell object. The operator then reviews the automatically selected cell objects, with the benefit of the measured cell object attribute values and accepts or changes the automatic selection of cell objects. In a preferred embodiment, each selected cell object is assigned to one of six classes and the indicia of selection consists of indicia of the class into which the associated cell object has been placed. The measured DNA mass of identified cell object fragments in tissue section samples may also be increased to represent the DNA mass of the whole cell object from which the fragment was sectioned.

Número - Título: US08296075 - Computer system and computer-facilitated method for nucleic acid sequence alignment and analysis 
Classes: G06F 19/00; G06F 15/00; G06F 17/30 (702/20 ; 700/1; 707/706)

Resumo: The present invention relates to a computer system and methods of computer-facilitated data analysis for providing reliable DNA alignments. More specifically, the invention relates to the automation of alignment and naming of mitochondrial DNA sequences for use in forensic analysis. The methods of the present invention provide consistency of sequence nomenclature by minimizing alignment ambiguities, thus providing a common functional system within and among laboratories.

Número - Título: US20020072863 - Method and apparatus for extracting and evaluating mutually similar portions in one-dimensional sequences in molecules and/or three-dimensional structures of molecules

Classes: G06F 19/00, G01N 033/48 (702/22)

Resumo: In the analysis of one-dimensional sequences of molecules, the longest common subsequence, the number of elements constituting the subsequence, and appearance positions of the subsequence are determined by a novel and simple method, and processes, such as homology decision, homology search, motif search and alignment are performed based on the results. In the analysis of these-dimensional structures of molecules, limiting conditions, such as geometrical arrangements of elements, are introduced to realize the determination of correspondence of three-dimensional structures at high speeds, and whereby it is made possible to achieve such processing as superposed display of three-dimensional structure of molecules, retrieval of three-dimensional structure, and evaluation of functions. Moreover, the molecules are divided into secondary structure that are then related to each other based on spatial similarity among the secondary structures. Furthermore, similarity among the molecules is decided based on a relationship of spatial positions of the corresponding secondary structures.

Número - Título: US20020098517 - Rapid determination of protein global folds

Classes: G01N 033/53; G06F 019/00; G01N 033/48; G01N 033/50; G01N 024/00 (435/7.1 ; $436 / 173 ; 702 / 19)$

Resumo: This invention provides a method for rapidly obtaining accurate three-dimensional structure of proteins including large or multi-sub unit proteins, using a combination of NMR analysis of backbone only .sup.13C, .sup.15N or .sup.13C and .sup.15N isotopically labeled proteins which are optionally also .sup.2H isotopically labeled in the C.alpha. position protons and residual dipolar coupling measurements in more than one partially aligned state. 
Número - Título: US20030088364 - Rapid determination of protein global folds

Classes: G01N 033/53; G06F 019/00; G01N 033/48; G01N 033/50 (702/19 ; 435/7.1)

Resumo: This invention provides a method for rapidly obtaining accurate three-dimensional structure of proteins including large or multi-sub unit proteins, using a combination of NMR analysis of backbone only .sup.13C, .sup.15N or .sup.13C and .sup.15N isotopically labeled proteins which are optionally also .sup.2H isotopically labeled in the C.alpha. position protons and residual dipolar coupling measurements in more than one partially aligned state and/or orientation data pertaining to overlapping successive peptide pairs.

Número - Título: US20030167131 - Method for constructing, representing or displaying protein interaction maps and data processing tool using this method

Classes: G06F 19/26;G06F 19/00;G06F 19/18 (702/19)

Resumo: An interaction map construction and representation method in which references of proteins are represented with links corresponding to alleged interactions between said proteins, wherein a score representing the significance of the protein-protein interaction is determined for each interaction and the scores of the represented interactions are indicated on the interaction map in the vicinity of the interactions to which they correspond.

Número - Título: US20050266411 - Methods for rapid forensic analysis of mitochondrial DNA

Classes: C12Q 001/68; G06F 019/00; G01N 033/48; G01N 033/50 (435/6.12; 702/20)

Resumo: The present invention provides methods for rapid forensic analysis of mitochondrial $D N A$ by amplification of a segment of mitochondrial DNA containing restriction sites, digesting the mitochondrial DNA segments with restriction enzymes, determining the molecular masses of the restriction fragments and comparing the molecular masses with the molecular masses of theoretical restriction digests of known mitochondrial DNA sequences stored in a database.

Número - Título: US20060069515 - Method and system for protein folding trajectory analysis using patterned clusters

Classes: G06F 19/00 (702/19)

Resumo: A method (and system) of analyzing protein folding trajectory includes a combinatorial pattern discovery process for analyzing multidimensional data from a simulation of the protein folding trajectory. The method of analyzing protein folding trajectory allows a user to understand the global state changes and folding mechanism of a protein during its folding process. The method may further include generating a collection of data points by 
simulation experiments, analyzing the collection of data points to extract patterned clusters, filtering the patterned clusters to remove insignificant patterned clusters to obtain a collection of filtered patterned clusters and analyzing the collection of filtered pattern clusters.

Número - Título: US20060100787 - Synthesis of nanocodes, and imaging using scanning probe microscopy

Classes: G06F 19/00 (702/19;702/20)

Resumo: Methods for making nanocodes that can be detected using scanning probe microscopy are provided, as are nanocodes constructed of two or more polymers, including homogeneous polymers such as nucleic acid molecules and heterogeneous polymers such as peptide nucleic acid polymers, and subunits useful for constructing such nanocodes. Also provided are modified nanocodes such as a nanocode containing one or more linked metals such as gold or iron and/or a linked probe that can specifically bind a target molecule. In addition, systems are provided that include such nanocodes, for example, a system that includes the nanocode and a surface and/or a scanning probe microscope probe. Methods of using such nanocodes, for example, to detect and/or identify a target molecule in a sample (e.g., a biological or environmental sample) using scanning probe microscopy, also are provided.

Número - Título: US20060212227 - An Analysis Platform for Annotating Comprehensive Functions of Genes on high throughput and Integrated Bioarray System

Classes: G06F 19/00 (702/19;702/20)

Resumo: This invention presents the analysis platform for annotating comprehensive functions of genes on high throughput and integrated bioarray system. High throughput and Integrated bioarray system produces the integrated information or data as functional patterns of DNA, RNA, protein, cDNA, tissue, and etc. from the same piece of biomaterials in a high throughput manner by vertical and comprehensive analysis. Horizontal and comprehensive analysis of the functional patterns of DNA, RNA, protein, cDNA, tissue, and etc., across different biomaterials under different conditions forms the three-dimensional database for the comprehensive functions of genes. The comprehensive functions of any gene or all related genes can be annotated from the three-dimensional database by computerized analysis. The analysis platform technologies with high throughput and integrated bioarray system are highly effective and powerful not only in getting vital information and data in the functions of genes but also in processing the obtained information and, furthermore, providing new strategies in diagnosis and treatments of diseases.

Número - Título: US20070016375 - Method and apparatus for extracting and evaluating mu- 
tually similar portions in one-dimensional sequences in molecules and/or three-dimensional structures of molecules

Classes: G06F 19/00 (702/19;702/22)

Resumo: In the analysis of one-dimensional sequences of molecules, the longest common subsequence, the number of elements constituting the subsequence, and appearance positions of the subsequence are determined by a novel and simple method, and processes, such as homology decision, homology search, motif search and alignment are performed based on the results. In the analysis of these-dimensional structures of molecules, limiting conditions, such as geometrical arrangements of elements, are introduced to realize the determination of correspondence of three-dimensional structures at high speeds, and whereby it is made possible to achieve such processing as superposed display of three-dimensional structure of molecules, retrieval of three-dimensional structure, and evaluation of functions. Moreover, the molecules are divided into secondary structure that are then related to each other based on spatial similarity among the secondary structures. Furthermore, similarity among the molecules is decided based on a relationship of spatial positions of the corresponding secondary structures.

Número - Título: US20080215301 - Method and apparatus for predicting protein structure

Classes: G06F 19/00 (703/11)

Resumo: A method of determining predicting putative contacting sites of a target protein is disclosed. The method uses a substitution matrix for calculating contact probabilities for pairs of columns in a sequence alignment containing the amino acid sequence of the target protein. The contact probabilities can also be used for predicting the three-dimensional structure of the protein. The putative contacts and/or three-dimensional structure typically correspond to the hydrophobic core of the target protein.

Número - Título: US20090182511 - Methods For Rapid Forensic Analysis Of Mitochondrial DNA And Characterization Of Mitochondrial DNA Heteroplasmy

Classes: G06F 19/00 (702/19)

Resumo: The present invention provides methods for rapid forensic analysis of mitochondrial DNA and methods for characterizing heteroplasmy of mitochondrial DNA, which can be used to assess the progression of mitochondrial diseases.

Número - Título: US20100145626 - Systems for rapid forensic analysis of mitochondrial DNA and characterization of mitochondrial DNA heteroplasmy

Classes: G06F 19/00; B01D 59/44; B01D059/44; G01N 33/48; G01N033/48 (702/19 ; 250/281) 
Resumo: The present invention provides methods for rapid forensic analysis of mitochondrial DNA and methods for characterizing heteroplasmy of mitochondrial DNA, which can be used to assess the progression of mitochondrial diseases.

Número - Título: US20100191517 - METHOD FOR DETERMINING THREE-DIMENSIONAL STRUCTURES OF DYNAMIC MOLECULES

Classes: G06F 19/00; G06F 19/16 (703/11)

Resumo: The present invention relates to a method for determining three-dimensional structures of molecules, particularly, but not exclusively, dynamic organic molecules of biological interest such as peptides, carbohydrates, proteins and drug molecules. A first aspect of the present invention provides a method for generating data representing an ensemble of threedimensional structures of a molecule, the molecule comprising first and second atoms linked by at least one bond, said bond having an associated angle, and the angle varying to generate a plurality of three-dimensional structures of said molecule, the method comprising: receiving data representing said molecule, said data comprising data indicating variability of said angle; and generating an ensemble of structures such that the angle has an associated value selected based upon said variability. A second aspect of the present invention provides a computer implemented method for simulating the variability of the three-dimensional structure of a molecule.

Número - Título: US20110178716 - Method for determining volume and hemoglobin content of individual red blood cells

Classes: G06F 19/00 (702/19)

Resumo: Provided herein is a method for determining the volume or hemoglobin content of an individual red blood cell in a sample containing a population of red blood cells. The method may be performed on a hematology analyzer. Also provided are a hematology analyzer for performing the method and a computer-readable medium containing programming for performing the method.

Número - Título: US20110246084 - METHODS AND SYSTEMS FOR ANALYSIS OF SEQUENCING DATA

Classes: G06F 19/10 (702/20)

Resumo: The present technology relates to the methods and systems for analysis of sequencing data. In particular, methods and systems for characterizing a target nucleic acid while determining the nucleotide sequence of the target nucleic acid are described. Certain embodiments include methods and systems for identifying the source of a target nucleic acid 
by comparing the accumulating nucleotide sequence of a target nucleic acid to a population of reference nucleotide sequences.

Número - Título: US20110251813 - METHOD AND APPARATUS FOR CLOCK SYNCHRONIZATION

Classes: G06F 19/00 (702/89)

Resumo: A system for synchronizing components of a downhole system includes: a source assembly including a source clock; an electromagnetic source associated with the source assembly and configured to emit an electromagnetic signal into an earth formation at a transmission time; a receiver assembly including a receiver clock; an electromagnetic receiver associated with the receiver clock and configured to detect the electromagnetic signal; and a processor configured to identify a receipt time of the electromagnetic signal based on the receiver clock and adjust the receiver clock by comparing the transmission time to the receipt time.

Número - Título: US20120150479 - Debug Access with Programmable Return Clock

Classes: G06F 19/00 (702/125)

Resumo: A debug port configured to generate and provide a return clock is disclosed. In one embodiment, an integrated circuit (IC) includes one or more functional units and a debug port (DP). The DP is configured to enable access by an external debugger to the functional unit(s) of the IC for debugging purposes. The DP includes circuitry that may generate a first clock signal that is provided to the functional unit(s) during debug operations. Receiving test result data at the DP may require a return clock signal that is not provided by the functional unit(s). Accordingly, the IC may include a clock modifier coupled to receive the first clock signal. The clock modifier may generate a second clock signal based on the first, the second clock signal being provided to the DP as a return clock signal.

Número - Título: US20120232803 - CHARACTERIZATION OF BLOOD HEMOSTASIS AND OXYGEN TRANSPORT PARAMETERS

Classes: G06F 19/00 (702/19)

Resumo: An integrated system for determining a hemostasis and oxygen transport parameter of a blood sample, such as blood, is disclosed. The system includes a measurement system, such as an ultrasonic sensor, configured to determine data characterizing the blood sample. For example, the data could be displacement of the blood sample in response to ultrasonic pulses. An integrated aspect of the system may be a common sensor, sample portion or data for fast and efficient determination of both parameters. The parameters can also be used to correct or improve measured parameters. For example, physiological adjustments 
may be applied to the hemostatic parameters using a HCT measurement. Also, physical adjustments may be applied, such as through calibration using a speed or attenuation of the sound pulse through or by the blood sample. These parameters may be displayed on a GUI to guide treatment.

Número - Título: US20120253687 - METHOD FOR ANALYZING RNA

Classes: G06F 19/00 (702/19)

Resumo: A method of analyzing RNA extracted from a tissue or cell(s) fixed with a fixative, said method comprising a determining step of whether said RNA satisfies: B/A.ltoreq.1 wherein $A$ represents the weight ratio (\%) of RNA within the range of 1000 to 4000 nucleotides with respect to the total weight of $R N A$ as determined by electrophoresis; and $B$ represents the weight ratio (\%) of $R N A$ within the range of more than 4000 nucleotides with respect to the total weight of RNA as determined by electrophoresis.

Número - Título: US20120310584 - AUTOMATED AND COORDINATED SIMULATION OF MULTIPLE CONCURRENT USER INTERACTIONS

Classes: G06F 19/00 (702/119)

Resumo: A method and associated system are provided for testing components of a vehicle entertainment system, comprising: interconnecting, via a network, a server computer comprising media content, and a plurality of user computers comprising software and hardware via which the user can interact with the media content; loading a test agent component onto a first of the user computers; loading a first scenario file comprising a series of user entry events that emulate user entry actions via a user interface device of the first user computer; executing the user entry events of the first scenario file by the test agent to generate system events that would normally be generated by a user operating the first user computer to interact with media server; and responding to the first user computer, by the server computer, to the system events.

Número - Título: US2012095694 - Quantifying measurements of protein, involves selecting metric for determining substantially optimal combination of true and false positives in data set, applying optimization technique, and obtaining optimization parameter value

Classes: G06F-019/10 (702/19)

Resumo: Methods and systems for high-confidence utilization of datasets are disclosed. In one embodiment, the method includes selecting a metric for determining substantially optimal combination of true positives and false positives in a data set, applying an optimization technique, and obtaining, from the results of the optimization technique, a value for at least 
one optimization parameter, the value for at least one optimization parameter resulting in substantially optimal combination of true positives and false positives. A number of true positives and a number of false positives are a function of the one or more optimization parameters.

Número - Título: US2012109535 - Predicting the probability of relapse of prostate cancer comprises providing expression levels for a collection of signature genes of interest from the test prostate tissue sample

Classes: G06F-019/24 (702/19)

Resumo: The present disclosure provides a method for cancer relapse prediction that provides higher resolution grading than Gleason score alone. In particular, the method provides for prediction of prostate cancer relapse that correlates gene expression of each individual signature gene and deriving a prostate cancer gene expression (GEX) score in the plurality of prostate cancer tissue samples; and correlating said GEX score with the clinical outcome for each prostate carcinoma tissue sample. A set of signature genes is provided that encompasses all or a sub-combination of GI_2094528, KIP2, NRG1, NBL1, Prostein, CCNE2, CDC6, FBP1, HOXC6, MKI67, MYBL2, PTTG1, RAMP, UBE2C, Wnt5A, MEMD, $A Z G P 1, C C K, M L C K, P P A P 2 B$, and PROK1.

Número - Título: US2012123691 - Methods of determining early signal attenuation (ESA) in signals from analyte sensors, involves generating output value based on probability analysis performed based on prior analyte sensor data to determine presence of signal attenuation

Classes: G06F-019/24 (702/19)

Resumo: Methods and devices to detect analyte in body fluid are provided. Embodiments include receiving one or more analyte sensor data, receiving a reference measurement value associated with an analyte level, determining a sensitivity parameter based on the received one or more analyte sensor data and the reference measurement value, performing a probability analysis based on prior analyte sensor data to determine presence of signal attenuation, and generating an output value based on the probability analysis.

Número - Título: US2012123760 - Computer modeling method for determining aptamer sequence involves individually modeling binding energy of different second oligomers to first binding site and selecting second oligomer that has most favorable binding energy

Classes: G06F-019/12 (703/11)

Resumo: Disclosed in this specification is a method for identifying at least one aptamer that can bind to a bio-molecular target. The aptamer is designed in silico based on the structure 
of the target molecule. The process includes the steps of determining a first seed residue and growing an oligomer, one residue at a time, while maximizing the entropy of targetoligomer complex or minimizing the binding energy after the addition of each oligomer.

Número - Título: US2012143580 - Computer-implemented method for determining preferred binding pose of ligand in target protein-ligand complex, involves evaluating relative quantitative scores to identify binding poses consistent with observed peak pattern

Classes: G06F-019/12 (703/11)

Resumo: A method of enhancing the throughput and applicability of NMR-based structure determination of protein-ligand complexes is disclosed. The method circumvents the need for protein sequence-specific resonance assignments and combines NMR data analysis and ligand docking methods into an integrated process. In one embodiment, NMR data is used to filter docking results to identify the most consistent binding modes, thereby providing structural information in a high-throughput fashion without the need for assigning protein resonances. Trial assignments for protein-ligand nuclear Overhauser effect (NOE) interactions are also produced by the method.

Número - Título: US2012232862 - Method for developing computer model of human generic receptor for patient in clinic, involves identifying biological processes related to region within human brain, and combining processes to form simulation of activity of region

Classes: G06G7/60, G06F19/12 (703/2, 703/11)

Resumo: A computer model of a diseased human brain includes inputs representing a drug and outputs representing the clinical effect of that drug on psychiatric and cognitive diseases. Diseases that can be modeled include psychiatric disorders, such as schizophrenia, bipolar disorder, major depression, ADHD, autism, obsessive-compulsive disorder, substance abuse and cognitive deficits therein and neurological disorders such as Alzheimer's disease, Mild Cognitive impairment, Parkinson's disease, stroke, vascular dementia, Huntington's disease, epilepsy and Down syndrome. The computer model preferably uses the biological state of interactions between and among cortico and subcortical areas of the human brain, to define the biological processes related to the biological state of the generic synapse model, the striatum, Locus Coeruleus, Dorsal raphe, hippocampus, amygdala and cortex, as well as certain mathematical relationships related to interactions among biological variables associated with the biological processes and to correlations between the biological variables and clinical effects on a clinical scale.

Número - Título: US2012253689 - Producing hybridization probe of target reference com- 
plete genomic sequence, involves determining count of number of times subsequence of first screened sequence occurs in target reference genomic sequence

Classes: G06F-019/20 (702/20)

Resumo: Single copy sequences suitable for use as DNA probes can be defined by computational analysis of genomic sequences. The present invention provides an ab initio method for identification of single copy sequences for use as probes which obviates the need to compare genomic sequences with existing catalogs of repetitive sequences. By dividing a target reference sequence into a series of shorter contiguous sequence windows and comparing these sequences with the reference genome sequence, one can identify single copy sequences in a genome. Probes can then be designed and produced from these single copy intervals.

Número - Título: US2012259556 - Computer implemented method for analyzing nucleic acid sequence, involves identifying indels with respect to reference sequence by determining difference between expected intervening sequence length and observed intervening sequence length

Classes: G06F-019/16 (702/20)

Resumo: Systems, methods, and analytical approaches for short read sequence assembly and for the detection of insertions and deletions (indels) in a reference genome. A method suitable for software implementation is presented in which indels may be readily identified in a computationally efficient manner.

Número - Título: US2012264115 - Determining presence or absence of fetal chromosomal aneuploidy in maternal test sample comprising fetal and maternal nucleic acid molecules, involves using sequence information for fetal and maternal nucleic acids in sample

Classes: G06F-019/10; G06F-019/20 (435/6.1)

Resumo: The present invention provides a method capable of detecting single or multiple fetal chromosomal aneuploidies in a maternal sample comprising fetal and maternal nucleic acids, and verifying that the correct determination has been made. The method is applicable to determining copy number variations (CNV) of any sequence of interest in samples comprising mixtures of genomic nucleic acids derived from two different genomes, and which are known or are suspected to differ in the amount of one or more sequence of interest. The method is applicable at least to the practice of noninvasive prenatal diagnostics, and to the diagnosis and monitoring of conditions associated with a difference in sequence representation in healthy versus diseased individuals.

Número - Título: US5546323 - Methods and apparatus for measuring tissue section thickness 
Classes: $702 / 170,382 / 133,702 / 105,702 / 20$

Resumo: An apparatus and method for measuring the thickness of a tissue section with an automated image analysis system, preferably using polyploid nuclear DNA content, for subsequent use in analyzing cell objects of a specimen cell sample for the diagnosis and treatment of actual or suspected cancer or monitoring any variation in the nominal thickness in a microtome setting. An image of a measurement material, such as a rat liver tissue section, having known cell object attributes is first digitized and the morphological attributes, including area and DNA mass of the cell objects, are automatically measured from the digitized image. The measured attributes are compared to ranges of attribute values which are preestablished to select particular cell objects. After the selection of the cell objects, the operator may review the automatically selected cell objects and accept or change the measured cell object attribute values. In a preferred embodiment, each selected cell object is assigned to one of three classes corresponding to diploid, tetraploid and octoploid cell morphology and the measured DNA mass of the identified cell object fragments in the rat liver tissue section sample may be corrected. Next, the selected cell objects of the measurement material, e.g., DNA Mass, are then graphically displayed in a histogram and the thickness of the rat liver tissue section can be measured based upon the distribution.

Número - Título: US5557535 - Method and system for protein modeling

Classes: $702 / 22,703 / 11,703 / 12$

Resumo: A method in a computer system for modeling a three-dimensional structure of a model protein is provided. In a preferred embodiment, the modeling is based upon a threedimensional structure of a template protein and an amino acid sequence alignment of the model protein and the template protein. The proteins comprise a plurality of amino acids having backbone atoms and side chain atoms. For each amino acid in the model protein, when the template protein has an amino acid aligned with the amino acid of the model protein, the position of each backbone atom of the amino acid of the model protein is established based on the position of a topologically equivalent backbone atom in the aligned amino acid of the template protein. The inter-atomic distance constraints for each pair of atoms with an established position is generated. Finally, the position of each atom in the model protein is set so that the inter-atomic distances are in accordance with the constraints.

Número - Título: US6125332 - Method and device for displaying a compound structure

Classes: $702 / 32,703 / 12$

Resumo: A method and a device for displaying a structure of a compound provide a graphic display and a related character display, affording improved operational characteristics. Stereo 
structural data obtained from a database is stored in a display buffer provided with a designated area for setting a display mode, thereby displaying graphically a stereo structure of said compound corresponding to the display mode set in said designated area and displaying characters representing said structure of said compound corresponding to said display mode set in said designated area.

Número - Título: US6512981 - Protein fold recognition using sequence-derived predictions

Classes: $702 / 19,435 / 4$

Resumo: A computer-assisted method for assigning an amino acid probe sequence to a known three-dimensional protein structure. In particular, the invention includes a method for using the amino acid sequence of a probe plus sequence-derived properties of the probe in making fold assignments. The method includes inputting into a computer system a string p.sub.1, p.sub.2 . . p.sub.n describing the amino acid sequence of the probe sequence and at least one sequence-derived property for the probe sequence; inputting into a computer system a string t.sub.1, t.sub.2 . . . t.sub.m of structural properties for each member of a library of known $3 D$ structures; executing an alignment algorithm in the computer to compute an alignment score indicating the optimal alignment of the string p.sub.1, p.sub.2 . . . p.sub.n to each string t.sub.1, t.sub.2 . . t.sub.m by applying a combined compatibility function $g(p . s u b . i$, t.sub.j); determining the statistical significance of each alignment score to determine a best-fit alignment score; and applying the best-fit alignment score to indicate or select the corresponding $3 D$ protein structure from the library for output to a user. The invention includes a computer program implementation of such a method.

Número - Título: US6629040 - Isotope distribution encoded tags for protein identification

Classes: $702 / 23,250 / 281,530 / 409,702 / 19$

Resumo: The present invention provides methods and reagents for identifying specific masses of compounds in a complex mixture. In particular, the present invention describes an isotope distribution encoded tag (IDEnT) concept wherein the ability to distinguish an analyte encoded with a non-native isotope from those not encoded with the isotope or from those encoded with a different isotope is used for protein identification, enzyme active site identification, peptide sequencing, and the like. Reagents used in the IDEnT strategy consist of a chemical element with a unique isotope distribution not normally found in the analyte class being studied, chemically bonded to, or an integral part of a chemical reagent with a high selectivity of affinity for specific functional group in the analyte.

Número - Título: US6671628 - Methods for identifying a molecule that may bind to a target 
molecule

Classes: $702 / 27,703 / 11$

Resumo: Methods which may be implemented in computer systems for screening a database of candidate molecules to determine whether any particular subset of candidate molecules may be docked to a target molecule. These methods determine the force field of a target molecule only once and may be used for screening a large number of candidate molecules.

Número - Título: US6882939 - Rapid determination of protein global folds

Classes: $702 / 19,702 / 27$

Resumo: This invention provides a method for rapidly obtaining accurate three-dimensional structure of proteins including large or multi-sub unit proteins, using a combination of NMR analysis of backbone only .sup.13 C, .sup.15 N or .sup.13 C and .sup.15 N isotopically labeled proteins which are optionally also .sup.2 $\mathrm{H}$ isotopically labeled in the C.alpha. position protons and residual dipolar coupling measurements in more than one partially aligned state and/or orientation data pertaining to overlapping successive peptide pairs.

Número - Título: US7047136 - Interferometric technique for quantitating biological indicators

Classes: 702/19, 435/6.17, 435/91.1, 435/91.2, 702/20, 702/27, 706/45, 706/47

Resumo: A technique is described for quantitating biological indicators, such as viral load, using interferometric interactions such as quantum resonance interferometry. A diffusion curve for the biological indicator of interest is generated from at least two measurements from a patient sample. In some embodiments, the patient samples are in the form of a microarray output pattern to which the patient sample has been applied. After the diffusion curve has been generated, subsequent patient samples are mapped to the diffusion curve to provide a quantitative measure of the biological indicator of interest.

Número - Título: US7383134 - Method and/or system for analyzing biological samples using a computer system

Classes: $702 / 19,382 / 128,382 / 129,382 / 133,435 / 287.2,435 / 4,435 / 6.11,703 / 11$

Resumo: A method and/or system for making determinations regarding samples from biologic sources. A computer implemented method and/or system can be used to automate parts of the analysis.

Número - Título: US7386400 - Method and apparatus for extracting and evaluating mutually similar portions in one-dimensional sequences in molecules and/or three-dimensional structures of molecules 
Classes: G06F 19/00 (702/27)

Resumo: In the analysis of one-dimensional sequences of molecules, the longest common subsequence, the number of elements constituting the subsequence, and appearance positions of the subsequence are determined by a novel and simple method, and processes, such as homology decision, homology search, motif search and alignment are performed based on the results. In the analysis of these-dimensional structures of molecules, limiting conditions, such as geometrical arrangements of elements, are introduced to realize the determination of correspondence of three-dimensional structures at high speeds, and whereby it is made possible to achieve such processing as superposed display of three-dimensional structure of molecules, retrieval of three-dimensional structure, and evaluation of functions. Moreover, the molecules are divided into secondary structure that are then related to each other based on spatial similarity among the secondary structures. Furthermore, similarity among the molecules is decided based on a relationship of spatial positions of the corresponding secondary structures.

Número - Título: US7386429 - Wrinkle simulation software

Classes: $703 / 6,345 / 420,345 / 426,703 / 11$

Resumo: The present invention introduces a simulation software for displaying a human being comprised of a plurality of arm joints, wherein each of the plurality of arm joints comprises a 1st part and a 2nd part. The invention also displays one or more wrinkles on or near the joint of the 1st part and the 2nd part, wherein the 1st part and the 2nd part are connected, and the angle produced by the 1st part and 2nd part is variable. The more the value of the angle decreases, the more the amount and/or the height of the wrinkle increases, thereby enabling the wrinkle simulation software to display the movement of the human being and the movement of the 1st and the 2nd part in a realistic manner.

Número - Título: US7462818 - Determination of chemical empirical formulas of unknown compounds using accurate ion mass measurement of all isotopes

Classes: $250 / 282,702 / 19,702 / 23$

Resumo: A method of determining an empirical formula of an analyte ion from a measured mass spectrum including a main peak and one or more isotope peaks. The method comprises comparing a relative isotopic intensity of the measured isotope peak to a calculated relative isotopic intensity of an isotopic ion of a proposed empirical formula and comparing a relative mass defect of the measured isotope peak to a calculated relative mass defect of the isotopic ion of the proposed empirical formula. The proposed empirical formula is identified as a potential candidate for the analyte ion based on these comparisons. 
Número - Título: US7680606 - Two-step method to align three dimensional LC-MS chromatographic surfaces

Classes: $702 / 19$

Resumo: A two-step alignment method for temporally aligning LC-MS data files representative of three-dimensional chromatographic surfaces is disclosed. The method includes a pre-alignment step whereby the data files are roughly aligned using a transformation-based correlation analysis of base peak information. The pre-aligned files are used as input to a full alignment step, in which a correlation matrix is computed from the full MS scan information, and an optimal path is traced through the resultant correlation matrix to identify corresponding scan numbers. The use of the pre-alignment step substantially reduces the computational expense of the full alignment step and improves the accuracy and reliability of the alignment.

Número - Título: US7751987 - Method and system for predicting amino acid sequences compatible with a specified three dimensional structure

Classes: G06F 19/00 (702/27)

Resumo: A method for predicting an amino acid sequence compatible with a three-dimensional (3D) structure of a protein. A reduced virtual representation of the $3 D$ structure is constructed, and, for each position along the representation, its solvent accessibility is determined. For each position along the structure, an amino acid residue is randomly selected from a predefined group of amino acids having a solvent accessibility compatible with the solvent accessibility of the position. A Monte-Carlo simulation is performed on this devised protein in which an amino acid at a particular position is sequentially replaced with other amino acids having the same solvent accessibility, and an energy score is calculated for each rotamer. The lowest scoring rotamer for this position is then selected The MonteCarlo simulation is repeated for each position along the sequence, to obtain an amino acid sequence with the lowest total energy score.

Número - Título: US7818130 - Automated method and system for setting image analysis parameters to control image analysis operations

Classes: $702 / 19,382 / 128,382 / 133,382 / 282,382 / 286$

Resumo: A method and system for setting image analysis parameters to control image analysis operations. The method and system include collecting set of digital training images including a set of states for the set of digital training images. An objective function is defined to determine a relative quality of plural different parameter sets used for digital 
image analysis. Values for the plural different parameter sets that maximize (or minimize) the objective function are determined. The method and system increases a usability of high content screening technologies by reducing a required level of expertise required to configure digital image processing.

Número - Título: US7855356 - Determination of chemical empirical formulas of unknown compounds using accurate ion mass measurement of all isotopes

Classes: $250 / 281,250 / 282,702 / 19,702 / 23$

Resumo: A method of determining an empirical formula of an analyte ion from a measured mass spectrum including a main peak and one or more isotope peaks. The method comprises comparing a relative isotopic intensity of the measured isotope peak to a calculated relative isotopic intensity of an isotopic ion of a proposed empirical formula and comparing a relative mass defect of the measured isotope peak to a calculated relative mass defect of the isotopic ion of the proposed empirical formula. The proposed empirical formula is identified as a potential candidate for the analyte ion based on these comparisons.

Número - Título: US7877213 - System and methods for automated processing of multiple chemical arrays

Classes: $702 / 19$

Resumo: A system and method of operating a data processing system to provide feature extraction from an image obtained from a plurality of chemical arrays is disclosed. The method includes bifurcating processing of the image by performing image processing and post-processing. The image processing includes processing parts of the image, each part corresponding to a different one of the arrays, in an automated batch process, to produce image-processed outputs that are different from the image and contain information extracted from the image. The post-processing includes processing the image-processed outputs according to different post-processing protocols with respect to different ones of those parts of the image corresponding to at least two of the arrays, to produce post-processed outputs. The method includes outputting at least one of the image-processed outputs and/or at least one of the post-processed outputs.

Número - Título: US7917306 - Methods and systems for generating cell lineage tree of multiple cell samples

Classes: $702 / 20,435 / 41$

Resumo: A method of generating a cell lineage tree of a plurality of cells of an individual is provided. The method comprising: (a) determining at least one genotypic marker for each 
cell of the plurality of cells; and (b) computationally clustering data representing the at least one genotypic marker to thereby generate the cell lineage tree of the plurality of cells of the individual.

Número - Título: US7991560 - System, method, and computer software for the presentation and storage of analysis results

Classes: $702 / 19,435 / 6.11,536 / 24.5,702 / 20,703 / 11,707 / 700$

Resumo: A computer program product, and related systems and methods, are described that processes emission intensity data corresponding to probes of a biological probe array. The computer program includes a genotype and statistical analysis manager that determines absolute or relative expression values based, at least in part, on a statistical measure of the emission intensity data and at least one user-selectable statistical parameter. The analysis manager may also determine genotype calls for one or more probes based, at least in part, on the emission intensity data. The analysis manager may further display the absolute or relative expression values based, at least in part, on at least one user-selectable display parameter and/or a measure of normalized change between genotype calls. The measure of normalized change may be based, at least in part, on a comparison of genotype calls and a reference value.

Número - Título: US8032347 - Methods and apparatus for protein sequence analysis

Classes: $703 / 12,435 / 6.1,536 / 24.1,702 / 19,702 / 20,703 / 11$

Resumo: Apparatus, methods, media, signals and data structures for protein sequence analysis are disclosed. A method includes identifying, from among a first group of aligned protein sequences having at least a threshold degree of alignment with a first protein sequence, a second group of at least one of the aligned sequences having at least one insertion or deletion ("indel") relative to the first protein sequence satisfying a predefined condition. The apparatus may include a processor circuit configured to carry out the method.

Número - Título: US8045782 - Method of, and apparatus and computer software for, implementing image analysis protocols

Classes: 382/133, 382/103, 382/128, 382/134, 382/155, 382/159, 382/181, 382/224, 702/19, $702 / 21$

Resumo: A computer-based method for the development of an image analysis protocol for analyzing image data, the image data containing images including image objects, in particular biological image objects such as biological cells. The image analysis protocol, once developed, is operable in an image analysis software system to report on one or more measure- 
ments conducted on selected ones of the image objects. The development process includes providing functions for selecting predetermined image analysis procedures, the functions allowing the user to define: at least one first target identification setting for identifying a first target set of image objects in the image data; at least one second target identification setting for identifying a second target set of image objects in the image data; a relationship between the first and second set of image objects; and one or more measurements which are to be reported for the image data, the measurements being conducted using the defined relationship.

Número - Título: US8078432 - Binding evaluation method for macromolecular compound

Classes: $703 / 2,702 / 27,703 / 11$

Resumo: A method for evaluating the binding of an evaluation target molecule with respect to a macromolecular compound based on numerical calculations and which detects the binding sites of the evaluation target molecule with respect to the macromolecular compound as a site where electronic states in a predetermined restricted region including the evaluation target molecule and the part of the macromolecular compound, which is adjacent to the evaluation target molecule, are unstable.

Número - Título: US8086410 - Methods of detecting DNA variation in sequence data

Classes: $702 / 19,435 / 6.1,702 / 20$

Resumo: A method for detecting DNA variation. First, by aligning trace data of a sample DNA sequence to trace data of a reference DNA sequence to produce an aligned sample DNA sequence. Then, inputting the trace data of the bases of both the reference DNA sequence and the aligned sample DNA sequence for a particular frame number into a non-linear mathematical function of an anti-correlation calculation scheme for all the frame numbers. Minimal values will be produced at the particular frame number for DNA base trace data of the aligned sample DNA sequence which are not a variation as compared to the reference $D N A$ sequence. Values above the minimal values will be produced at the particular frame number for DNA base trace data of the aligned sample DNA sequence which are a variation as compared to the reference DNA sequence.

Número - Título: US8117020 - Method to determine the degree and stability of blood glucose control in patients with diabetes mellitus via creation and continuous updating of new statistical indicators

Classes: $703 / 11,435 / 3,702 / 19,702 / 22,703 / 12$

Resumo: Systems and methods for determining a stability of a blood glucose concentration of a 
patient are provided. The system comprises a processor that may be programmed to receive blood glucose concentration test results each taken from the patient at a different time over a time period and to compute a time-averaged glucose parameter indicative of blood glucose concentration control over the time period. In addition, the processor may be programmed to compute a virtual blood hemoglobin parameter through a simulated measurement of a blood hemoglobin, the virtual blood hemoglobin parameter being indicative of blood glucose concentration control over an extended time period encompassing the time period. Further, the processor may be programmed to compute a lability factor parameter indicative of a variability in blood glucose concentration over the time period.

Número - Título: US8126656 - Molecular design method and computer-readable storage medium

Classes: G06F 19/10;G06F 19/00;G06F 19/16 (702/27; 702/22)

Resumo: A computer-implemented molecular design method constructs and stores a data structure including an atomic data structure, a bond axis data structure, a molecular data structure, an auxiliary data structure, and an event data structure, with respect to data of a given three-dimensional (3D) molecular structure. A partial structure that is a modifying target is determined using the data structure, based on an atom or bond axis that is specified. A modified 3D molecular structure in which the partial structure has been subjected to a modifying operation is specified. An Undo or Redo operation is performed on the specified modifying operation using the data structure.

Número - Título: US8200389 - Information providing method for producing operating condition of power plant of vehicle involves determining difference between actual injector on time and calculated injector on time for various engine speeds and engine loads

Classes: G01M 15/05; G06F 19/26 (701/34.4;340/439; 701/29.1; 701/31.7; 701/33.9)

Resumo: An analysis tool which extracts all the available parameter identifications (i.e. PIDS) from a vehicle's power train control module for diagnostic decisions. This is done by checking these PIDS and other information (e.g., calculated PIDS, Break Points, charts and algorithms) in three states; key on engine off, key on engine cranking, key on engine running. In all three modes the tool is comparing the live data from PIDS and voltage to the other information (e.g, Break Points). If any of this data are outside the programmed values a flag is assigned to the failure or control problem. The relationship between a particular PID and its associated preprogrammed value(s) may be indicated by a light. The depth of the problem (if any) is conveyed by the color of the light. Also included are tests/charts for fuel trim, engine volumetric efficiency, simulated injector, power, catalyst efficiency, and engine coolant range. 
Número - Título: US8225407 - Method for managing network security incident, involves updating initial group of recommended responsive actions based on secondary set of data

Classes: G06F-019/24 (726/25;726/23)

Resumo: Providing adaptive response recommendations for a network security incident comprising at least one underlying security event is disclosed. A first set of data associated with the event is received. An initial group of one or more recommended responsive actions to be taken in response to the event is identified based at least in part on the first set of data. A second set of data associated with the event is received. The initial group of one or more recommended responsive actions is updated based at least in part on the second set of data associated with the event.

Número - Título: US8249814 - Method, computer readable medium, and system for determining a probability of colorectal cancer in a test subject

Classes: $702 / 19,703 / 11$

Resumo: Disclosed is a method of testing for colorectal cancer in a test individual by providing data corresponding to a level of products of selected biomarkers and applying the data to a formula to provide an indication of whether the test individual has colorectal cancer. Also disclosed are kits for measuring data corresponding to the products of selected biomarkers, and kits and methods of monitoring therapeutic efficacy of treatments for colorectal cancer.

Número - Título: US8260596 - Method and composition for crystallizing G protein-coupled receptors

Classes: $703 / 11 ; 715 / 771$

Resumo: Certain embodiments provide a method for crystallizing a GPCR. The method may employ a fusion protein comprising: a) a first portion of a G-protein coupled receptor (GPCR), where the first portion comprises the TM1, TM2, TM3, TM4 and TM5 regions of the GPCR; b) a stable, folded protein insertion; and c) a second portion of the GPCR, where the second portion comprises the TM6 and TMY regions of the GPCR.

Número - Título: US8263375 - Dynamic monitoring of activation of G-protein coupled receptor (GPCR) and receptor tyrosine kinase (RTK) in living cells using real-time microelectronic cell sensing technology

Classes: $435 / 173.4 ; 435 / 173.1 ; 435 / 173.5 ; 435 / 173.8 ; 435 / 285.2 ; 435 / 288.4 ; 702 / 19$

Resumo: The present application includes systems and methods for identifying a compound capable of interacting with a G-Protein Coupled Receptor (GPCR) or Receptor Tyrosine 
Kinase (RTK) including providing a device capable of measuring cell-substrate impedance operably connected to an impedance analyzer, adding test cells expressing a GPCR or a RTK to wells of the device, measuring first impedances of the wells and optionally determining first cell indices from the first impedances, adding a compound to at least one well containing test cells to form at least one compound well and adding a vehicle control to at least another well containing test cells to form at least one control well, measuring second impedances of the compound well and the control well and optionally determining second cell indices from the second impedances, determining the change in the impedance or cell index for the compound well and the one control well, comparing the change in impedance or cell index between the compound well and the control well, and identifying the compound interacts with the GPCR or RTK if the comparison demonstrates a significant difference between the change in impedance or cell index of the compound well and the control well.

Número - Título: US8265877 - Apparatus and method for analyzing a metabolite profile

Classes: $702 / 19$

Resumo: An apparatus and method analyzes a metabolic profile in a biological sample. The apparatus includes an input unit for inputting the drugs and/or metabolites to be screened; a controlling unit for determining a parameter set for metabolites preparation and for mass spectrometry analysis depending on the input of the kind of metabolites to be screened; a treatment unit for preparing the metabolites to be screened depending on the determined parameter set; a mass spectrometer for performing mass spectrometry analysis on prepared metabolites depending on the parameter set; a database for storing results of analyzing and parameter sets for metabolite preparation and for mass spectrometry analyses; and an evaluation unit for evaluating the results of mass spectrometry by use of reference results stored in the database to output an analysis of the metabolites profile.

Número - Título: US8265880 - Gene expression level analyzing method, gene expression level anlayzing program, and gene expression level analyzing device

Classes: $702 / 20,365 / 94,435 / 6.1,700 / 1$

Resumo: A gene expression level analyzing method includes the steps of: acquiring expression levels of a plurality of target genes in a target cell every measurement time; extracting a maximum expression level and a minimum expression level from the expression levels of the target genes every measurement time; calculating a correlation coefficient of a frequency distribution of the gene having the maximum expression level at each measurement time and a frequency distribution of the gene having the minimum expression level at each measurement time; and comparing the correlation coefficient with a threshold value of the correlation coefficient. 
Número - Título: US8271203 - Methods and systems for sequence-based design of multiple reaction monitoring transitions and experiments

Classes: $702 / 19 ; 250 / 282 ; 435 / 5 ; 703 / 11$

Resumo: Computer-implementable methods consistent with the present teachings can be used in the design of selective- and multiple-reaction monitoring experiments for the identification of proteins and peptides of interest. By determining candidate parent-daughter ion transition pairs and scoring the pairs based on their ability to be detected experimental design time can be reduced and with a more focused list of transition pairs more experiments can be run successfully in a given period of time.

Número - Título: US8271204 - Human recognition apparatus and human recognition method

Classes: $702 / 19 ; 345 / 473 ; 345 / 475 ; 702 / 141 ; 702 / 189$

Resumo: Provided are a human recognition apparatus and a human recognition method identifying a user based on a walking pattern. The human recognition apparatus includes a detecting unit detecting a vibration according to a user's walking, and outputting an electric signal, a pattern calculating unit acquiring a walker's walking pattern from the electric signal, and a user determining unit comparing the walking pattern with a previously measured reference data by user and identifying the user based on the comparison result. The human recognition apparatus and the human recognition method are robust against peripheral noise and can increase an acceptance rate through a simple structure and procedure by using the waling pattern, which is one-dimensional time information requiring no vast data throughput, as the user identification data.

Número - Título: US8271250 - Molecule design support apparatus and computer-readable storage medium

Classes: $703 / 11$

Resumo: A molecule design support apparatus has an input part, a display to display on a screen thereof a three-dimensional molecular structure by a half vector format or a ball-and-stick format, and a determining part to determine, in the molecular structure, an end that is to become a target of a coordinate modification with respect to a molecule in its entirety, in response to a bond axis of the molecule specified from the input part. The apparatus further has a modifying part to make a modification of the molecular structure based on the specified bond axis and the end that is the target of the coordinate modification, in response to the modification specified from the input part, and a display part to display a modified molecular structure on the screen of the display based on a determination made by the 
determining part and the modification made by the modifying part.

Número - Título: US8271251 - Automated imaging system for single molecules

Classes: $703 / 12,703 / 6$

Resumo: There is provided a high throughput automated single molecule image collection and processing system that requires minimal initial user input. The unique features embodied in the present disclosure allow automated collection and initial processing of optical images of single molecules and their assemblies. Correct focus may be automatically maintained while images are collected. Uneven illumination in fluorescence microscopy is accounted for, and an overall robust imaging operation is provided yielding individual images prepared for further processing in external systems. Embodiments described herein are useful in studies of any macromolecules such as DNA, RNA, peptides and proteins. The automated image collection and processing system and method of same may be implemented and deployed over a computer network, and may be ergonomically optimized to facilitate user interaction.

Número - Título: US8271427 - Computer database system for single molecule data management and analysis

Classes: $707 / 600,702 / 19,707 / 705,707 / 790$

Resumo: A computer database system for storing, processing, displaying, and analyzing single molecule data is capable of managing and processing variously formatted, different kinds of single molecule data and displaying subsets thereof upon instructions by a user. A component-based architecture is implemented where the processing and the displaying are separately performed. The data is dynamically loaded for processing as needed. Embodiments of computer database systems can be utilized in managing single molecule data, particularly image data derived from single molecule images. Such single molecule images may be generated by a variety of technologies, e.g., optical mapping, atomic force microscopy (AFM), scanning tunneling microscopy (STM), and flow cytometry. Systems may be deployed over a computer network. One or more additional databases may be included which are interconnected through a network.

Número - Título: US8275595 - Computer-based methods of designing molecules

Classes: $703 / 12 ; 703 / 11$

Resumo: The invention features a method of generating an immunogenic compound with the ability to induce an immune response to a molecule produced by a pathogenic agent, e.g., a infectious agent or a tumor cell. Also included in the invention are an immunogenic 
compound generated by the method of the invention and a method of inducing an immune response in a mammal that involves administering the immunogenic compound to the mammal.

Número - Título: US8278055 - Methods and device for analyte characterization

Classes: $435 / 7.1,436 / 518,702 / 19$

Resumo: The methods and apparatus, disclosed herein are of use for sequencing and/or identifying proteins, polypeptides and/or peptides. Proteins containing labeled amino acid residues may be synthesized and passed through nanopores. A detector operably coupled to a nanopore may detect labeled amino acid residues as they pass through the nanopore. Distance maps for each type of labeled amino acid residue may be compiled. The distance maps may be used to sequence and/or identify the protein. Apparatus of use for protein sequencing and/or identification is also disclosed herein. In alternative methods, other types of analytes may be analyzed by the same techniques.

Número - Título: US8280643 - Crystal structure of Staphylococcus aureus clumping factor A in complex with fibrinogen derived peptide and uses thereof

Classes: $702 / 19$

Resumo: The present invention provides a method for determining the structure of a microbial surface components recognizing adhesive matrix molecule in complex with fibrinogen, by providing a ClfA complexed with a fibrinogen gamma-peptide; determining a ClfA binding region of the fibrinogen gamma-peptide; determining one or more critical amino acid residues in the ClfA binding region of a native fibrinogen gamma-peptide that is critical for a ClfA:fibrinogen gamma-peptide interaction; determining one or more amino acid residues of the ClfA that binds to the ClfA binding region of the native fibrinogen gamma-peptide; modeling the structure of the ClfA binding region; determining the structure of the ClfA in complex with the :fibrinogen gamma-peptide interaction; and identifying one or more potential agent(s) that inhibit the ClfA:fibrinogen gamma-peptide interaction without affecting binding of other proteins to the fibrinogen gamma-peptide.

Número - Título: US8280711 - Sequence based engineering and optimization of single chain antibodies

Classes: $703 / 11 ; 702 / 20 ; 707 / 706$

Resumo: The invention provides methods of using sequence based analysis and rational strategies to modify and improve the structural and biophysical properties of single chain antibodies (scFvs), including stability, solubility, and antigen binding affinity. These methods and 
strategies can be used individually or in combination. The methods of the present invention also include the use of a database comprising scFv sequences from an experimentally screened scFv library of antibodies that have been selected to have superior solubility and stability. The invention also provides methods of using the properties found for these selected antibodies in a general approach for reshaping scFv antibodies to improve stability and solubility properties of a single chain antibody fragment.

Número - Título: US8285490 - Method and system for obtaining improved data perfusion measurements

Classes: $702 / 19$

Resumo: A method of deriving blood perfusion indices for a region of interest (ROI) of a subject, comprising the steps of administering a contrast agent to the subject during a dynamic imaging scan, converting signal intensity data from raw images of the scan into contrast agent concentration data, deriving parameters from the contrast agent concentration data using at least one transport function that accounts for delay and dispersion of the contrast agent, and calculating the blood perfusion indices from the derived parameters.

Número - Título: US8287739 - Measuring hematocrit and estimating hemoglobin values with a non-invasive, optical blood monitoring system

Classes: $210 / 739 ; 210 / 134 ; 210 / 143 ; 210 / 645 ; 210 / 646 ; 210 / 745 ; 210 / 85 ; 210 / 86 ; 210 / 97$; $356 / 39 ; 356 / 40 ; 422 / 50 ; 422 / 68.1 ; 436 / 43 ; 436 / 70 ; 600 / 301 ; 600 / 328 ; 600 / 485 ; 604 / 4.01$; $604 / 5.01 ; 604 / 5.04 ; 604 / 6.07 ; 702 / 19$

Resumo: An optical blood monitoring system with a ratiometric model determines hematocrit values for a hemodialysis patient, from which hemoglobin values for the patient are estimated. The ratiometric model is calibrated, normally against a cell counter, using blood from a blood bank. The blood from a blood bank is preserved in a long term preservative which is typically different than that found in clinical settings. The hematocrit value determined by the ratiometric model is scaled by scaling factor so that the estimated hemoglobin level output from the monitor consistently matches that measured in a clinical setting. The hematocrit scaling factor is substantially about 1.033 when the patient's blood sample is stored in a short term preservative ethylene diamine tetra acetic, and is substantially about 1.06 when the hematocrit is measured in the blood sample without preservative being added to the blood sample. The hemoglobin value can also be adjusted for altitude.

Número - Título: US8289323 - Drawing processing apparatus, texture processing apparatus, and tessellation method 
Classes: $345 / 423 ; 345 / 419 ; 345 / 424 ; 345 / 428 ; 345 / 441 ; 345 / 582 ; 703 / 11 ; 703 / 6$

Resumo: A drawing processing apparatus for performing tessellation processing, comprising a pixel shader and a texture unit. An internal division operation part of the pixel shader issues texture load instructions to the texture unit, specifying parametric coordinate values of a patch of a parametric surface, and thereby acquires internal division factors interpolated based on the parametric coordinate values from the texture unit. The internal division operation part issues texture load instructions to the texture unit further, specifying the internal division factors acquired from the texture unit as new interpolation factors, and thereby acquires control points internally divided based on the internal division factors in advance from the texture unit. Based on the internal division factors corresponding to the parametric coordinate values, the internal division operation part performs recursive internal division operations on the control points acquired from the texture unit, thereby determining a point on the parametric surface corresponding to the parametric coordinate values.

Número - Título: US8296070 - Method and apparatus for improved simulation of chemical and biochemical reactions

Classes: $702 / 19,702 / 20$

Resumo: An integrated system for modeling, simulating and analyzing chemical and biochemical reactions includes a modeling environment for constructing a model of a chemical or biochemical reaction. The system also includes a simulation engine accepting as input said constructed model of the chemical or biochemical reaction and generating as output an expected result for a first chemical reaction using a first type of computational model and an expected result for a second chemical reaction using a second type of computational model. An analysis environment communicates with the simulation engine and displays the expected result.

Número - Título: US8296071 - Methods for uniformly treating biological samples with electromagnetic radiation

Classes: $702 / 19$

Resumo: Methods, devices and device components are presented for uniformly treating fluids undergoing mixing with electromagnetic radiation. In one aspect, the present invention provides methods of treating a fluid undergoing continuous fluid mixing wherein net radiant energies necessary to provide uniform treatment of the fluid samples with electromagnetic radiation are calculate on the basis of the volume, mass or mixing rate of the fluid or any combination of these variables. In another aspect, the present invention provides 
algorithms for determining net radiation energies, radiant powers, and/or illumination times necessary for providing uniform treatment of fluid samples. The present invention provides methods for uniformly reducing pathogens in biological fluids, including blood and blood components.

Número - Título: US8296072 - Techniques for recording signals

Classes: $702 / 19 ; 702 / 20 ; 703 / 11 ; 707 / 700$

Resumo: The present invention provides techniques of recording signals. In one aspect of the invention, a method of recording a signal comprises the following steps. One or more errors are selectively introduced during synthesis of a polymer in response to the signal. The one or more occurrences of the one or more errors in the synthesized polymer are recorded. The synthesis of the polymer may comprise a polymer synthetase that can selectively introduce the one or more errors in response to the signal. A method for analyzing signals is also provided.

Número - Título: US8296074 - Melting curve analysis with exponential background subtraction

Classes: $702 / 19 ; 435 / 6.1 ; 700 / 1$

Resumo: A method for clustering melting profiles of a plurality of nucleic acid samples, comprising measuring the fluorescence of each nucleic acid sample as a function of temperature to produce a respective raw melting curve for each respective nucleic acid sample, and clustering genotypes of the plurality of nucleic acid samples to form a plurality of clusters of melting curves. A system for analyzing a plurality of nucleic acid samples comprising an instrument for sequentially heating fluorescently detectable complexes while monitoring their fluorescence, a central processing unit (CPU) for performing computer executable instructions, and a memory storage device for storing computer executable instructions that when executed by the CPU cause the CPU to cluster genotypes of a plurality of nucleic acid samples.

Número - Título: US8296075 - Computer system and computer-facilitated method for nucleic acid sequence alignment and analysis

Classes: $702 / 20,700 / 1,707 / 706$

Resumo: The present invention relates to a computer system and methods of computer-facilitated data analysis for providing reliable DNA alignments. More specifically, the invention relates to the automation of alignment and naming of mitochondrial DNA sequences for use in forensic analysis. The methods of the present invention provide consistency of sequence 
nomenclature by minimizing alignment ambiguities, thus providing a common functional system within and among laboratories.

Número - Título: US8296076 - Noninvasive diagnosis of fetal aneuoploidy by sequencing

Classes: $702 / 20$

Resumo: Disclosed is a method to achieve digital quantification of DNA (i.e., counting differences between identical sequences) using direct shotgun sequencing followed by mapping to the chromosome of origin and enumeration of fragments per chromosome. The preferred method uses massively parallel sequencing, which can produce tens of millions of short sequence tags in a single run and enabling a sampling that can be statistically evaluated. By counting the number of sequence tags mapped to a predefined window in each chromosome, the over- or under-representation of any chromosome in maternal plasma DNA contributed by an aneuploid fetus can be detected. This method does not require the differentiation of fetal versus maternal DNA. The median count of autosomal values is used as a normalization constant to account for differences in total number of sequence tags is used for comparison between samples and between chromosomes.

Número - Título: US8296107 - Computer method and apparatus for constraining a non-linear approximator of an empirical process

Classes: $703 / 2 ; 703 / 12 ; 703 / 13 ; 706 / 14 ; 706 / 25$

Resumo: A constrained non-linear approximator for empirical process control is disclosed. The approximator constrains the behavior of the derivative of a subject empirical model without adversely affecting the ability of the model to represent generic non-linear relationships. There are three stages to developing the constrained non-linear approximator. The first stage is the specification of the general shape of the gain trajectory or base non-linear function which is specified graphically, algebraically or generically and is used as the basis for transfer functions used in the second stage. The second stage of the invention is the interconnection of the transfer functions to allow non-linear approximation. The final stage of the invention is the constrained optimization of the model coefficients such that the general shape of the input/output mappings (and their corresponding derivatives) are conserved.

Número - Título: US8296108 - Time series data analyzer, and a computer-readable recording medium recording a time series data analysis program

Classes: $703 / 2 ; 600 / 27 ; 600 / 300 ; 600 / 301 ; 600 / 323 ; 600 / 428 ; 600 / 431 ; 600 / 483 ; 600 / 500$; $600 / 509 ; 600 / 544 ; 607 / 40 ; 607 / 45 ; 702 / 183 ; 702 / 186 ; 702 / 189 ; 702 / 191 ; 703 / 11 ; 706 / 20 ;$ $706 / 52$ 
Resumo: A time series data analyzer includes a segment condition input section, an analysis condition input section, and an optimum condition deriving section for analyzing all segments based on the segment conditions and analysis conditions inputted in the respective input sections, under all analysis conditions by a maximum entropy method and a nonlinear least squares method. The time series data analyzer derives the optimum segment length and the optimum lag value in correspondence to selected results, and an analysis execution section executes analysis by the maximum entropy method by setting the optimum analysis conditions derived as described above. The trending of the spectrum of electroencephalogram data is used as an indicator of the state of the subject based on the findings that the spectrum of electroencephalogram data is an exponential spectrum and the gradient changes depending on the state of the subject.

Número - Título: US8296116 - Bioinformatics system

Classes: $703 / 11 ; 700 / 30 ; 702 / 19 ; 707 / 769$

Resumo: The invention develops models of functional proteomics. Simulation scenarios of protein pathway vectors and protein-protein interactions are modeled from limited information in protein databases. The system focuses on three integrated subsystems, including (1) a system to model protein-protein interactions using an evolvable Global Proteomic Model (GPM) of functional proteomics to ascertain healthy pathway operations, (2) a system to identify haplotypes customized for specific pathology using dysfunctional protein pathway simulations of the function of combinations of single nucleotide polymorphisms (SNPs) so as to ascertain pathology mutation sources and (3) a pharmacoproteomic modeling system to develop, test and refine proposed drug solutions based on the molecular structure and topology of mutant protein(s) in order to manage individual pathologies. The system focuses on simulating the degenerative genetic disease categories of cancer, neurodegenerative diseases, immunodegenerative diseases and aging. The system reveals approaches to reverse engineer and test personalized medicines based upon dysfunctional proteomic pathology simulations.

Número - Título: US8296300 - Method for reconstructing protein database and a method for screening proteins by using the same method

Classes: $707 / 737 ; 702 / 19 ; 702 / 23 ; 702 / 27 ; 703 / 2 ; 706 / 13 ; 707 / 708 ; 707 / 722 ; 707 / 771 ; 707 / 776$; $707 / 802$

Resumo: The present invention relates to a method for reconstructing protein database for identifying a protein and a method for screening a protein using the same, more precisely a method for reconstructing protein database, and a method for identifying a protein using the same. The method for reconstructing protein database and the method for identifying 
the protein of the invention are very useful for the investigation of endogenous proteins and their functions and interactions, and are further effectively used for the development of diagnostic and therapeutic agents for various diseases.

Número - Título: US8301391 - Identifying components of a network having high importance for network integrity

Classes: $702 / 19 ; 370 / 252 ; 370 / 254 ; 709 / 238$

Resumo: A computer system (2) is provided which is arranged to receive network data (1) identifying nodes and links between nodes. The computer system (2) processes the input network data (1) to utilize the network topology to identify nodes and links having high importance for network integrity. A report (4) identify the critical components can then be output.

Número - Título: US8538718 - Clock edge grouping for at-speed test

Classes: G06F 19/00 (702/117)

Resumo: A method of grouping clock domains includes: separating a plurality of test clocks into a plurality of domain groups by adding to each respective one of the plurality of domain groups those test clocks that originate from a same clock source and have a unique clock divider ratio; sorting the domain groups in decreasing order of size; and creating a plurality of parts by adding the respective one of the plurality of domain groups to a first one of the plurality of parts in which already present test clocks have a different clock source, and creating a new part and adding the respective one of the plurality of domain groups to the new part when test clocks present in the respective one of the plurality of domain groups originate from a respective same clock source and have a different clock divider ratio as test clocks present in all previously-created parts. 